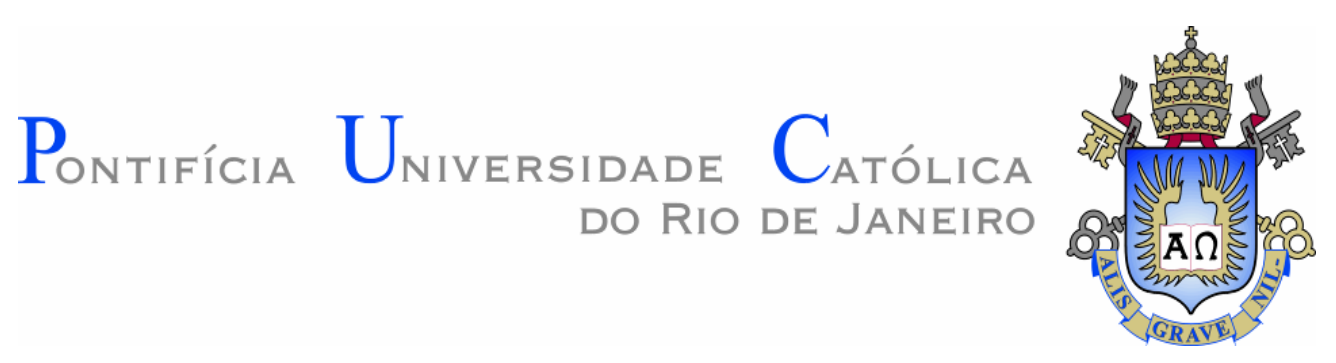

Ana Luiza Lopes Viana

O fenômeno da violência como campo de intervenção da Política de Assistência Social: entre a reparação de direitos e o controle punitivo

Dissertação de Mestrado

Dissertação apresentada ao Programa de Pósgraduação em Serviço Social da PUC-Rio como requisito parcial para obtenção do grau de Mestre em Serviço Social.

Orientadora: Prof. ${ }^{a}$ Ariane Rego de Paiva

Rio de Janeiro

Abril de 2020 


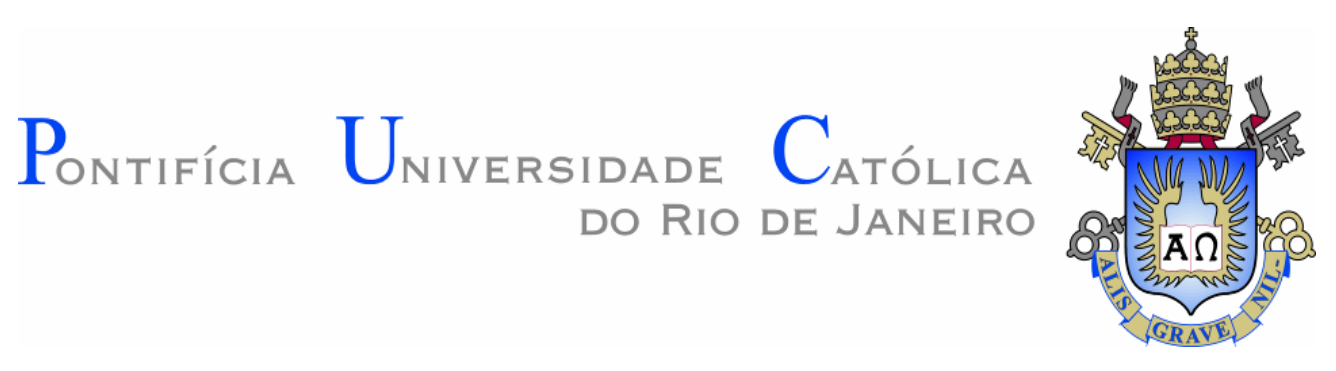

Ana Luiza Lopes Viana

\section{O fenômeno da violência como campo de intervenção da Política de Assistência Social: entre a reparação de direitos e o controle punitivo}

Dissertação apresentada como requisito parcial para obtenção do grau de Mestre pelo Programa de Pósgraduação em Serviço Social da PUC-Rio. Aprovada pela Comissão Examinadora abaixo.

Profa. Ariane Rego de Paiva Orientadora Departamento de Serviço Social - PUC-Rio

Prof. Antonio Carlos de Oliveira Departamento de Serviço Social - PUC-Rio

Profa. Miriam Krenzinger Azambuja Guindani Escola de Serviço Social - UFRJ

Profa. Mônica de Castro Maia Senna Departamento de Serviço Social - UFF

Rio de Janeiro, 30 de abril de 2020. 
Todos os direitos reservados. É proibida a reprodução total ou parcial do trabalho sem autorização da universidade, da autora e do orientador.

\section{Ana Luiza Lopes Viana}

Graduou-se em Serviço Social na UFRJ (Universidade

Federal do Rio de Janeiro) em 2006. Especialista em Direito Especial da Criança e do Adolescente pela Universidade do Estado do Rio de Janeiro (UERJ).

Ficha Catalográfica

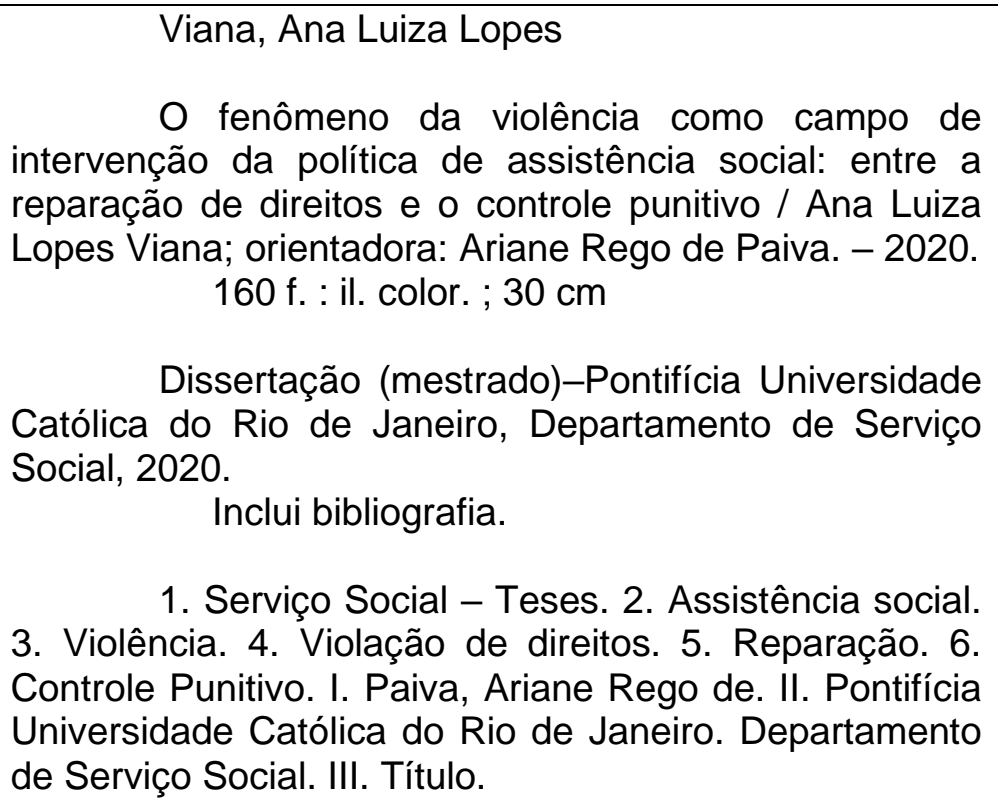
intervenção da política de assistência social: entre a reparação de direitos e o controle punitivo / Ana Luiza Lopes Viana; orientadora: Ariane Rego de Paiva. - 2020. 160 f. : il. color. ; $30 \mathrm{~cm}$

Dissertação (mestrado)-Pontifícia Universidade Católica do Rio de Janeiro, Departamento de Serviço Social, 2020. Inclui bibliografia.

1. Serviço Social - Teses. 2. Assistência social. 3. Violência. 4. Violação de direitos. 5. Reparação. 6. Controle Punitivo. I. Paiva, Ariane Rego de. II. Pontifícia Universidade Católica do Rio de Janeiro. Departamento de Serviço Social. III. Título. 


\section{Agradecimentos}

À minha orientadora Ariane Paiva pela parceria, disponibilidade e incentivo. Nossas trocas redefiniram não apenas os rumos da dissertação, como também projetos profissionais e perspectivas de mundo.

Aos professores da linha de pesquisa 2 - Violência, Direitos, Serviço Social e Políticas Intersetoriais - Antonio Carlos de Oliveira, Irene Rizzini e, mais uma vez, Ariane Paiva pela acolhida, escuta e partilha de ensinamentos. A minha trajetória na PUC-Rio foi marcada por um referencial de cuidado e apoio, combinação que julgava como impossível na formação stricto sensu. Sou imensamente grata a vocês pela oportunidade de desconstrução e expansão de horizontes!

Aos professores e aos funcionários do Departamento de Serviço Social da Puc-Rio, pelas importantes contribuições e suporte - fundamentais para a caminhada acadêmica.

Às professoras que participaram de ambas as bancas - Míriam Guindani e Mônica Senna, além do professor Antonio Carlos de Oliveira. Preservar a mesma formação foi fundamental para a avaliação de um processo, que contou com observações, contribuições e palavras de incentivos tão caras para a conclusão da dissertação.

À PUC-Rio, pelos auxílios concedidos, sem os quais este trabalho não poderia ter sido realizado.

À Jocimara Theodoro pela confiança e apoio - seu incentivo profissional me possibilitou alcançar lugares, sustentar posicionamentos e, assim, me reencontrar como Assistente Social. A intensidade dos seus projetos me desafiou para além dos domínios da PCRJ. Foi um privilégio compartilhar e discordar tantas e tantas vezes!

À Maíra Mendes pela presença, escuta, cuidado e afeto. As perguntas que encarei ao longo da pesquisa foram apresentadas (de forma exaustiva, eu sei) a você, quando ainda não tinham forma e, até mesmo, sentido. Mas você sempre esteve comigo, presente, atenta, alerta, ácida e, sempre, cativante. Muito obrigada 
minha amiga e madrinha, a conclusão dessa etapa é um presente, pelo qual você tem inestimáveis e afetuosos créditos.

À Luzia Teixeira pelos abraços e sorrisos de todas, absolutamente, todas as horas! Que sorte minha partilhar da sua luz, minha amiga e madrinha!

Ao meu filho, Alan Lopes, pelo amor, cumplicidade, sorrisos cativantes e registros intensos de saudade. Agradeço por toda a força e inspiração que sua perspectiva de mundo me proporciona, incentivos e afetos que me fazem seguir adiante.

Ao meu marido, Paulo Octávio Viana, por me fazer acreditar, quando por vezes (e não foram poucas) pensei em desistir, questionei o sentido e a razão de voltar à vida acadêmica. Obrigada por ter feito minha inscrição online para a seleção do mestrado, por ter me levado para a fazer a prova (dirigindo na velocidade da luz), por ter contido minhas mãos trêmulas antes da entrevista, pelo incentivo criativo (quando este já estava esgotado), enfim, por ter feito da dissertação um projeto nosso, desde sempre! Você irradia uma força que extrapola as palavras, é amor que se faz presente, que insiste e persiste.

À minha mãe, Corina Lopes, por embarcar nos meus projetos com tanta força e dedicação, ainda que sem entender, apenas por confiar. Seu apoio incondicional é tradução de amor, referência para toda uma vida! Muito obrigada mãe, por tudo! 


\section{Resumo}

Viana, Ana Luiza Lopes; Paiva, Ariane Rego de. O fenômeno da violência como campo de intervenção da Política de Assistência Social: entre a reparação de direitos e o controle punitivo. Rio de Janeiro, 2020. 160p. Dissertação de Mestrado - Departamento de Serviço Social, Pontifícia Universidade Católica do Rio de Janeiro.

A presente dissertação analisa os arranjos normativos que qualificam expressões do fenômeno da violência como campo de intervenção da Política Nacional de Assistência Social - PNAS/2004. Trata-se de uma pesquisa de abordagem qualitativa, pautada no método da análise documental, que se deteve ao exame das concepções que informam e os atributos que reivindicam a violência como objeto da Assistência Social, vinculado, no desenho institucional vigente, à Proteção Social Especial de Média Complexidade. A interpretação dos dados se deu a partir do método de análise de conteúdo qualitativa, recurso que permitiu identificar a coexistência do discurso protetivo com elementos que remetem ao controle punitivo das famílias, em especial dos núcleos em situação de pobreza. Os resultados obtidos permitem reconhecer a paradoxal relação entre proteção e punição nos arranjos contemporâneos da Política de Assistência Social, os quais são instituídos num contexto democrático, marcado por um notório avanço do conservadorismo, porém ainda vigentes sob o signo do Estado de direito.

\section{Palavras-chave}

Assistência Social; Violência; Violação de Direitos; Reparação; Controle Punitivo. 


\section{Abstract}

Viana, Ana Luiza Lopes; Paiva, Ariane Rego de (Advisor). The phenomenon of violence as a field of intervention of the Social Assistance Policy: between the repair of rights and the punitive control. Rio de Janeiro, 2020. 160p. Dissertação de Mestrado Departamento de Serviço Social, Pontifícia Universidade Católica do Rio de Janeiro.

This dissertation analyzes the normative arrangements that qualify expressions of the phenomenon of violence as a field of intervention of the National Social Assistance Policy - PNAS / 2004. It is a qualitative research, based on the document analysis method, which stopped examining the concepts that inform and the attributes that claim violence as an object of Social Assistance, linked, in the current institutional design, to Special Social Protection of Medium Complexity. The interpretation of the data was based on the methodology of content analysis, a resource that allowed the identification of the coexistence of the protective discourse with elements that refer to the punitive control of families, especially those in situations of poverty. The results obtained allow us to recognize the paradoxical relationship between protection and punishment in the contemporary arrangements of the Social Assistance Policy, which are instituted in a democratic context, marked by a notable advance in conservatism, but still in force under the rule of law.

\section{Keywords}

Social Assistance; Violence; Violation of Rights; Repair; Punitive Control. 


\section{Sumário}

1. Introdução

2. A Constituição Histórica da Assistência Social sob a Perspectiva do

Binômio Proteção - Punição no Capitalismo.

2.1 Histórico das Ações Assistenciais no Capitalismo.

2.2 Histórico da Assistência Social no Brasil.

2.3. Tendências da Política de Assistência Social na Contemporaneidade

3. A abordagem da violência na Política de Assistência Social - notas sobre a reparação de direitos e o controle punitivo

3.1. A violência como objeto de intervenção da Política de Assistência Social

3.2. A reprodução do controle punitivo nos domínios da proteção social a dualidade do campo socioassistencial

3.3. A violação de direitos e a perspectiva reparatória na Política de Assistência Social.

4. A violência nos documentos da PNAS/2004 - análise do marco protetivo atribuído à PSE de média complexidade

4.1. O método da pesquisa

4.2. O percurso metodológico da pesquisa

4.3. Sistematização dos dados qualitativos - a transição temporal da abordagem ao fenômeno da violência nas publicações.

4.3.1. A violência nos documentos de formulação: do Programa Sentinela ao PAEFI.

4.3.2. A violência nos documentos de implementação: as expressões da violência como situações de risco e violação de direitos. 
4.3.3. A violência nos documentos de monitoramento e avaliação: a definição do campo de intervenção da PSE de média complexidade 137 4.3.4. A violência no eixo de formação continuada: a dualidade protetiva e punitiva como pauta de discussão da Política de Assistência Social. 144

5. Considerações Finais

6. Referências

153

7. Anexo

159

Anexo 1

159 


\section{Lista de quadros}

Quadro 1 - Relação dos documentos analisados 103

Quadro 2 - Fluxograma dos documentos analisados 107

Quadro 3 - Roteiro da pesquisa

108 


\section{Lista de figuras}

Figura 1 - Tabela de dados - morte por intervenção de agente do Estado.

Figura 2 - Evolução da taxa de aprisionamento no Brasil entre 2000 a 2016

Figura 3 - Pessoas privadas de liberdade por natureza da prisão e tipo de regime

Figura 4 - Quadro de avaliação das relações de convivência familiar 143 


\section{Siglas}
$\mathrm{BM}$
Banco Mundial
BNH Banco Nacional de Habitação
CAS Centro de Ação Social
CEME Central de Medicamentos
CF
Constituição Federal
CRAS
Centro de Referência de Assistência Social
CREAS Centro de Referência Especializado de Assistência Social
CIT Comissão Intergestores Tripartite

DATAPREV Empresa de Processamento de Dados e Previdência Social

ECA Estatuto da Criança e do Adolescente

FBSP Fórum Brasileiro de Segurança Pública

FGTS Fundo de Garantia do Tempo de Serviço

FIOCRUZ Fundação Oswaldo Cruz

FMI Fundo Monetário Internacional

FUNRURAL Fundo de Assistência ao Trabalhador Rural

FUNABEM Fundação Nacional para o Bem-estar do Menor

IAPAS Instituto Nacional de Administração da Previdência Social

INAMPS Instituto Nacional de Assistência Médica

INPS Instituto Nacional de Previdência Social

IPEA Instituto de Pesquisa Econômica Aplicada
LA
(medida judicial de) Liberdade Assistida

LBA Legião Brasileira de Assistência

LOAS Lei Orgânica de Assistência Social

LGBT Lésbicas, Gays, Bissexuais, Travestis e Transexuais

MDS Ministério do Desenvolvimento Social e Combate à Fome

NOB/SUAS Norma Operacional Básica da Assistência Social

OMS Organização Mundial de Saúde

ONU Organização das Nações Unidas

PCRJ Prefeitura da Cidade do Rio de Janeiro

PAEFI Serviço de Proteção e Atendimento Especializado a Famílias

e Indivíduos 
PAIF Serviço de Proteção e Atendimento Integral à Família

PASEP Programa de Formação do Patrimônio do Servidor Público

PBF Programa Bolsa Família

PCB Partido Comunista do Brasil

PIS Programa de Integração Social

PNAS Política Nacional de Assistência Social

PNEP Política Nacional de Educação Permanente

PSB Proteção Social Básica

PSC (medida judicial de) Prestação de Serviços à Comunidade

PSE Proteção Social Especial

PETI Programa de Erradicação do Trabalho Infantil

PRONASCI Programa Nacional de Segurança Pública com Cidadania

PTRC Programa de Transferência de Renda Condicionada

RMA Registro Mensal de Atendimentos

RMV Renda Mensal Vitalícia

SAM Serviço de Assistência ao Menor

SCFV Serviços de Convivência e Fortalecimento de Vínculos

SGD Sistema de Garantia de Direitos

SICON Sistema de Gestão e Condicionalidades do PBF

SINPAS Sistema Nacional de Assistência e Previdência Social

SIM/MS Sistema de Informações sobre Mortalidade do Ministério da

Saúde

SNAS Secretaria Nacional de Assistência Social

SUAS Sistema Único de Assistência Social

SUSP Sistema Único de Segurança Pública

UNESCO Organização das Nações Unidas para a Educação, a Ciência e a Cultura 
Maria, Maria, É um dom,

Uma certa magia Uma força que nos alerta Uma mulher que merece

Viver e amar Como outra qualquer Do planeta

Maria, Maria, É o som, é a cor, é o suor É a dose mais forte e lenta De uma gente que ri Quando deve chorar E não vive, apenas aguenta

Mas é preciso ter força, É preciso ter raça É preciso ter gana sempre Quem traz no corpo a marca

Maria, Maria, Mistura a dor e a alegria Mas é preciso ter manha, É preciso ter graça É preciso ter sonho sempre Quem traz na pele essa marca Possui a estranha mania De ter fé na vida.

Milton Nascimento 


\section{1.}

\section{Introdução}

$\mathrm{O}$ presente estudo contempla o processo de institucionalização do fenômeno da violência como campo de intervenção da Política de Assistência Social, a partir do ciclo normativo inaugurado pela Política Nacional de Assistência Social no ano de 2004 (PNAS/2004). A análise se deteve ao eixo protetivo da Proteção Social Especial (PSE) de média complexidade, enquanto segmento socioassistencial de acompanhamento especializado às famílias e indivíduos em situação de risco, por violação de direitos ${ }^{1}$ - recorte que vincula as expressões de violência eleitas como específicas para a atuação do Serviço de Proteção e Acompanhamento Especializado a Famílias e Indivíduos (PAEFI).

A dissertação contempla o percurso de investigação desenvolvido no âmbito da Linha de Pesquisa 2 - Violência, Direitos, Serviço Social e Políticas Intersetoriais do Programa de Pós-Graduação da Pontifícia Universidade Católica do Rio de Janeiro (PUC-Rio). A dinâmica da pesquisa submeteu à análise o processo que normatizou expressões do fenômeno da violência como campo de intervenção próprio da Política de Assistência de Social, com base no exame crítico do desenho institucional vigente, pautado, em âmbito nacional, pelas normativas e produções definidas pelo Poder Executivo Federal.

A pesquisa objetivou analisar as concepções que qualificam o campo de intervenção e, em consequência, definem as expectativas de proteção atreladas à Política de Assistência Social no atendimento às situações de violência. Com efeito, a produção se debruçou na avaliação do ciclo da PNAS/2004², detida nas normativas referentes à PSE de média complexidade, ao Centro de Referência Especializado de Assistência Social (CREAS) e ao PAEFI. O investimento analítico

\footnotetext{
${ }^{1}$ Sentença que define a atuação da PSE de média complexidade na atualidade. Vale pontuar, que tal recorte sofreu alterações ao longo do processo de implementação da PNAS/2004. As modificações foram apontadas no decorrer da análise, em especial no Capítulo III, referente à sistematização dos resultados da pesquisa.

${ }^{2}$ Em tempo, cabe ressalvar que a análise envolveu a inclusão da normativa do Programa Sentinela, documento que se vincula ao ciclo da Política Nacional de Assistência Social de 1998. O contexto da modificação é explicitado na metodologia e apresentação dos resultados da pesquisa. De antemão, cabe enfatizar que o recorte de violência apresentado na PNAS/2004 possui relação com os encaminhamentos do ciclo anterior, razão pela qual a transição foi considerada como elemento fundamental para a avaliação da Política vigente.
} 
pressupôs o estudo da Política de Assistência Social sob o prisma da correlação paradoxal entre a reparação de direitos e o controle punitivo, a considerar o privilégio das expressões de violência intrafamiliar ${ }^{3}$ e de conflitos interpessoais como ocorrências que determinam o campo de atuação da PSE de média complexidade.

Em linhas gerais, a Assistência Social integra o tripé da Seguridade Social brasileira, em conjunto com as políticas de Saúde e Previdência Social. É regulamentada pela Lei Orgânica de Assistência Social (LOAS), cuja promulgação data do ano de 1993, com atualizações posteriores, em destaque a Lei $n^{\circ} 12.435$, de 2011, que incorpora o Sistema Único de Assistência Social (SUAS) como parâmetro para a organização, regulação e execução das ações socioassistenciais.

A PNAS/2004, por sua vez, apresenta a Assistência Social como política de proteção social, com a prerrogativa de garantir as seguintes seguranças: segurança de rendimento e autonomia, de acolhida e de convívio familiar. O documento define famílias e indivíduos, em situação de vulnerabilidade e riscos, como o público usuário da Política. No âmbito da gestão, a PNAS/2004 se estrutura na perspectiva do SUAS, o qual parametriza a regulação e organização nacional das ações socioassistenciais. Os serviços, programas, projetos e benefícios tem como foco prioritário a atenção às famílias e indivíduos, além do território como base de organização.

O SUAS é estruturado a partir de dois níveis de proteção, a conferir: a Proteção Social Básica (PSB) tem como objetivo prevenir situações de risco por meio do desenvolvimento de potencialidades e aquisições e o fortalecimento de vínculos familiares e comunitários; a PSE é a modalidade de atendimento destinada a famílias e indivíduos que se encontram em situação de risco pessoal e social, por violação de direitos, tais como - violência física, psicológica, negligência, abandono, violência sexual (abuso e exploração), situação de rua, trabalho infantil, práticas de ato infracional, fragilização ou rompimento de vínculos, afastamento do

\footnotetext{
${ }^{3}$ De acordo com o Ministério da Saúde, “a violência familiar é toda ação ou omissão que prejudique o bem-estar, a integridade física, psicológica ou a liberdade e o direito ao pleno desenvolvimento de outro membro da família. Pode ser cometida dentro ou fora de casa por algum membro da família, incluindo pessoas que passam a assumir função parental, ainda que sem laços de consanguinidade, e em relação de poder à outra. $\mathrm{O}$ conceito de violência intrafamiliar não se refere apenas ao espaço físico onde a violência ocorre, mas também as relações em que se constrói e efetua" (BRASIL, 2002, p. 18).
} 
convívio familiar, dentre outras violações e tipificações de violência (BRASIL, 2004; 2009; 2011).

No tocante à PSE, a PNAS/2004 determina o atendimento às famílias e indivíduos em situação de risco pessoal e social, com o propósito de garantir o acesso a serviços de apoio e sobrevivência, como a inclusão em redes sociais de atendimento e solidariedade (BRASIL, 2004). Na ótica da Política, as ações socioassistenciais da PSE devem desencadear estratégias de atenção sociofamiliar que contribuam para a elaboração de novas referências morais e afetivas, sendo direcionadas para grupos tidos como vulneráveis, como crianças, adolescentes, jovens, idosos, pessoas em situação de rua com direitos ameaçados ou violados (BRASIL, 2004).

Para tanto, a PSE encontra-se disposta em dois níveis de complexidade, a saber: a PSE de média complexidade destina-se às famílias e indivíduos com direitos violados, mas cujos vínculos familiar e comunitário não foram rompidos, a partir do PAEFI, Serviço Especializado em Abordagem Social, Serviço de proteção social a adolescentes em cumprimento de medida socioeducativa de Liberdade Assistida (LA) e de Prestação de Serviços à Comunidade (PSC), Serviço de Proteção Social Especial para Pessoas com Deficiência, Idosas e suas Famílias e Serviço Especializado para Pessoas em Situação de Rua; a PSE de alta complexidade volta-se para a proteção integral - moradia, alimentação, higienização e trabalho protegido - para famílias e indivíduos que se encontram sem referência e, ou, em situação de ameaça, sendo apartados de seu núcleo familiar e/ou comunitário, com a previsão do Serviço de Acolhimento Institucional, Serviço de Acolhimento em República, Serviço de Acolhimento em Família Acolhedora e Serviço de proteção em situações de calamidades públicas e de emergências (BRASIL, 2009).

Diante do quadro descrito, distintas categorias passaram a orientar a Política de Assistência Social e, por conseguinte, a PSE, a partir da PNAS/2004. É possível identificar menções, até então inéditas nos referenciais da Política, aos termos vulnerabilidade, território, risco social e pessoal, matricialidade familiar, vínculo familiar e comunitário, violência intrafamiliar, violação de direitos, vigilância socioassistencial, dentre outros. O estudo propõe que o exame dos conceitos explorados, ao longo dos documentos e normativas, contribuirá para 
demarcar as ocultações presentes na Política de Assistência Social, as quais privilegiam aspectos familiares e individuais como métrica de valoração das demandas e definição das coberturas socioassistenciais.

A argumentação sustenta que tais categorias, ao orientar a estrutura dos serviços e as formas de intervenção previstas na Política, privilegiam aspectos individuais e relacionais das famílias pobres. Trata-se de ressaltar a dimensão política do vocabulário da PNAS/2004, considerando um movimento de afirmação, no plano retórico, de categorias específicas do campo socioassistencial. A família vulnerável ou exposta a situações de riscos assume a titularidade das garantias previstas nas proteções sociais afiançadas pelo SUAS, com intervenções que redirecionam o acesso ao mercado e a preservação de vínculos familiares e comunitários. No campo específico da PSE, a Política reafirma a responsabilização da família, como instância primordial de cuidados e segurança, subtraindo, no entanto, expressões de violências que violam direitos e prerrogativas essenciais do direito à vida, como a violência de corte estrutural, próprias do modo de produção e reprodução capitalista.

Nestes termos, o estudo parte da problemática que situa as expressões de violência manifestas nas relações familiares e interpessoais como campo de intervenção da Política de Assistência Social, nos domínios da PSE de média complexidade e do PAEFI, decisivamente. A PNAS/2004 reporta a centralidade das ações de proteção social nas famílias, diretiva que se apresenta para a PSE de forma particular, a julgar tanto pela associação das ocorrências violadoras às relações privadas, como a perspectiva de reparação determinada pela autoproteção familiar. Em outros termos, a centralidade nas famílias se estende à apropriação do fenômeno da violência que orienta a Proteção Especial, considerando as expressões que são privilegiadas e a lógica de restauração de direitos pautada na dita capacidade protetiva das próprias famílias.

A proposição do estudo transcorre do vínculo profissional como assistente social da Prefeitura da Cidade do Rio de Janeiro (PCRJ), atrelada ao executivo municipal da Política de Assistência Social. A trajetória de atuação na Política acompanha um movimento de amadurecimento profissional e pessoal, considerando que a admissão à PCRJ aconteceu imediatamente após à conclusão da graduação em Serviço Social. Transição que acompanhou, portanto, um 
exercício particular de projeção das expectativas como assistente social, balizado por um compromisso ético-político, a ser materializado num contexto de expansão do SUAS, que, por sua vez, reatualizava a interpretação da Assistência Social por parte da categoria.

Volta-se, nesse ponto da exposição, ao ano de 2006, mais precisamente, aos debates que acirravam a identidade do assistente social como ator estratégico para a mediação da Política de Assistência Social, independente do campo político de intervenção. Além do problemático atravessamento, destaca-se o investimento em capacitações, de modo a introduzir um discurso assistencial com conotação técnica, com menção à conceitos e categorias de um arranjo normativo em conformação. Os profissionais que iriam compor o quadro de servidores da pasta deveriam incorporar tal retórica institucional, com o intuito de demarcar distinções com as demais políticas públicas, atribuir e reivindicar um campo de intervenção próprio e legitimar a proteção social como atributo da Política.

As reminiscências que vem à tona, caracterizando o início de um percurso profissional, guardam relação com as perguntas que atualmente orientam a investigação. O exercício por reconhecer pressupostos da formação crítica diante de um cenário nebuloso de definições e enquadramentos da população dita vulnerável e/ou em situação de risco é cotidiano, dada a necessidade de explorar e sustentar avaliações que se contraponham à uma realidade fragmentada, hoje estabelecida como campo legítimo para a intervenção dos serviços socioassistenciais. O questionamento acerca do dimensionamento da Assistência Social à época, tanto para a redução da perspectiva profissional - o assistente social como trabalhador que estabelece a mediação por excelência da Política -, como para sua amplitude enquanto proteção social, é retomado, a partir das inferências que problematizam a relação da violência e a centralidade na família como pressuposto da PSE.

O regresso ao universo acadêmico viabilizou um distanciamento abstrato, necessário para identificar, dentre tantas outras nuances da relação de trabalho, que a resistência firmada, ao longo dos últimos catorze anos, foi fundamental para prosseguir e reelaborar sentidos da prática profissional na PCRJ - hoje traduzida nos pressupostos que norteiam a investigação. Portanto, trata-se da relação subjetiva do pesquisador como parte da pesquisa, fomentada pelo envolvimento 
cotidiano com as repercussões de uma dada experiência profissional, a qual, mediada por uma elaboração teórica, converte-se em objeto de pesquisa. Isto posto, a formulação que problematiza as expressões do fenômeno da violência definidas como campo de intervenção da Política de Assistência Social, decorre da inserção nos serviços da PSE de média e alta complexidade, no âmbito da execução e gestão local ${ }^{4}$.

A partir do atendimento e acompanhamento às famílias em situação de violação de direitos - aqui, vale a ressalva, violações múltiplas, que extrapolam as ocorrências restritas às dinâmicas relacionais das famílias pobres - bem como aos grupos familiares e indivíduos com ou em vivência de acolhimento institucional, foi possível estabelecer os contrastes iniciais com as definições de violência que norteiam a Política de Assistência Social. Vale pontuar que o reconhecimento transcorre da ausência, na medida em que as medidas de reparação e garantias de direitos são direcionadas para fragmentos do fenômeno da violência, os quais, decisivamente, extrapolam as relações familiares. Em outras palavras, as ocorrências violadoras possuem estreita relação com expressões da violência estrutural, com repercussões que não são formalmente identificadas e, assim, omitidas nas fontes de registros previstas no SUAS.

A produção de dados relativos às violações de direitos e a construção de indicadores dos atendimentos da PSE explicitam a delimitação do fenômeno da violência na PNAS/2004, uma vez que orientados por categorias que privilegiam as ocorrências nas dinâmicas familiares. A transposição mensal dos atendimentos às planilhas de registros ${ }^{5}$ constituía um movimento de sistematização das intervenções e ocultação de uma gama de violações de direitos, quando afetos ao fenômeno da violência de corte estrutural. Ainda que se reconheça os limites dos registros quantitativos para a compreensão de trajetórias particulares, o que se impunha como

\footnotetext{
4 Atuação na função designada “Técnica de Proteção Social Especial”, vinculada às Coordenadorias de Assistência Social e Direitos Humanos, com atribuição de assessoria e supervisão das equipes que compõem os serviços locais. Conferir: Decreto municipal nº37.304, de 25 de junho de 2013 que regulamenta a estrutura organizacional da Secretaria Municipal de Assistência Social e Direitos Humanos.

5 O Registro Mensal de Atendimentos (RMA) é um sistema onde são registradas mensalmente as informações relativas aos serviços ofertados e o volume de atendimentos nos CRAS, CREAS e CENTRO POP. Trata-se de um instrumental voltado para uniformizar os dados e informações socioassistenciais, conforme as determinações das Resoluções da Comissão Intergestores Tripartite (CIT) $\mathrm{n}^{\circ} 4 / 2011 \mathrm{e} \mathrm{n}^{\circ} 20 / 2013$.
} 
obstáculo para o reconhecimento das famílias e indivíduos, atendidos diariamente nos serviços da PSE, eram as ausências de categorias que explicitassem, por exemplo, as intervenções motivadas por violências perpetradas por agentes da Segurança Pública e violações decorrentes da falta de serviços públicos essenciais, como unidades escolares e de saúde.

Além do estranhamento e inquietações provocadas pelo distanciamento dos dados produzidos e retroalimentados na dinâmica dos serviços da PSE, um outro aspecto disciplinador reverbera nas ações cotidianas dos serviços de média e alta complexidade: o trânsito de intervenções requisitadas pelo Sistema de Justiça, com especificações para quem, por que, como e quando atender, sob pena de sanções legais para as famílias e para as equipes das unidades de atendimento. Tal cenário ilustra e retoma as indagações que endossam a pesquisa, considerando a seleção de categorias que orientam a intervenção da PSE e o direcionamento contemporâneo da Assistência Social, enquanto estratégias de controle e contenção punitiva da pobreza.

Em 2015, o Instituto de Pesquisa Econômica Aplicada (IPEA) publicou os resultados da pesquisa As relações entre o Sistema Único de Assistência Social e o Sistema de Justiça, desenvolvida a partir da necessidade de compreensão dos problemas que circundam a relação entre o Sistema de Justiça e o SUAS (IPEA, 2015). O documento contempla os resultados da pesquisa, a partir de dois eixos norteadores - o panorama normativo em matéria de Assistência Social e a pesquisa jurisprudencial acerca de demandas socioassistenciais, que dizem respeito às relações entre os sistemas (IPEA, 2015).

Para efeito da discussão em pauta, cabe ressalvar o tema das requisições extraprocessuais, trâmite que caracteriza a existência de uma estreita relação entre o SUAS e o Sistema de Justiça, porém sem envolver necessariamente a existência de uma lide. De acordo com a publicação, o conflito se dá pelas requisições extraprocessuais emanadas pelo Sistema de Justiça e direcionadas ao SUAS, as quais apresentam pedidos das mais diversas ordens e abordam conteúdos inclusive não competentes ao SUAS (BRASIL, 2015). O panorama traçado, com base em encontros descentralizados com representações do SUAS e do Sistema de Justiça em todas as regiões do país, retrata uma relação de sujeição entre os Sistemas, 
O Sistema de Justiça dita ao SUAS o que fazer, como fazer e em quanto tempo fazer, e "dialoga" com ele a partir do lugar de cumpridor de tarefas. Ademais, destaca-se o caráter estritamente individual destes encaminhamentos, os quais estão voltados ao atendimento de demandas pessoalizadas, que não contemplam uma situação coletiva. (...) As requisições advindas dos diversos órgãos do Sistema de Justiça chegam, em regra, de forma individual, sob um aspecto autoritário, com ordens de cumprimento a prazos muito curtos. (BRASIL, 2015, p. 225)

Ao encaminhar as análises conclusivas da pesquisa, o relatório adverte que:

(...) corre-se o risco da Assistência Social estar sendo utilizada enquanto um instrumento de gestão informal da pobreza. A persistência do Sistema de Justiça no tratamento individual dos problemas pode caracterizar uma espécie de controle social informal sobre esta população pobre, o que significa gerar e reproduzir mais intensamente as desigualdades sociais (BRASIL, 2015, p. 226).

O estudo citado identificou elementos significativos da relação entre o

SUAS e o Sistema de Justiça, suscitando um debate sobre o viés de controle que as sanções legais impõem ao público dos serviços e ações da Política de Assistência Social, como o cerceamento das práticas e autonomia dos profissionais ligados ao SUAS. Não obstante, faz-se necessário ressalvar que a própria Política, nos contornos programáticos e normativos da PNAS/2004 e documentos posteriores, contribui para os descaminhos apurados, haja vista o enquadramento dos processos violadores que determinam o seu público alvo e a adoção de medidas de reparação de direitos atreladas, majoritariamente, às deliberações do Sistema de Justiça.

Diante de um quadro adverso, com projeções nebulosas dado o cenário político das recentes disputas eleitorais, a pesquisa se propôs ao debate do fenômeno da violência como campo de atuação da Política de Assistência Social, a partir da análise da PSE na PNAS/2004 e documentos de orientação normativa. O estudo vislumbrou contribuir para a necessária discussão das categorias relacionadas à PSE de média complexidade, em que pese o destaque acadêmico para os programas de transferência de renda e para a PSB nas produções do Serviço Social na última década.

É possível reconhecer, dentre os acadêmicos ligados à temática da Assistência Social, leituras que sugestionam o necessário investimento em estudos sobre a PSE. A título de ilustração, destacam-se as considerações presentes no livro "O Sistema Único de Assistência Social no Brasil: uma realidade em movimento" 
(COUTO et al, 2015). As autoras, ao apresentarem os resultados da pesquisa de avaliação da implantação do SUAS, em âmbito nacional, observam que “(...) a proteção especial e sua estrutura ainda carecem de maturação e compreensão" (COUTO et al, 2015).

No tocante às produções relacionadas à PSE, ressalta-se o investimento em estudos que privilegiam aspectos e/ou programas específicos, tais como as discussões sobre o trabalho infantil, medidas socioeducativas, violência sexual, população em situação de rua, internação compulsória e tantas outras expressões de violações de direito e violência abarcadas no SUAS. A despeito da relevância das publicações e pesquisas citadas, o presente estudo pretende contribuir para a análise dos pressupostos que determinam o escopo de intervenção da PSE de média complexidade, os quais subsidiam as frentes de atuação por segmentos e programas. Ou seja, a pesquisa persegue o desafio de apreender as categorias que delimitam o campo de atuação da PSE de média complexidade, em particular do PAEFI, as quais se colocam como referências para a estrutura dos programas e projetos voltados para grupos específicos.

Ademais, a pesquisa guardou a expectativa, ao partir da revisão de documentos normativos, de ter suscitado um diálogo crítico com as publicações institucionais. Observa-se a tendência da reprodução do acervo governamental como aporte para definições teóricas e análises de conjuntura, quando os mesmos encerram orientações programáticas de uma política pública em particular. O estudo objetivou demarcar que as categorias e premissas da PSE partem de uma dada concepção de Assistência Social, as quais são enunciadas e reelaboradas nas produções, autodenominadas técnicas, da Política. E, assim, contribuir para identificação dos limites, controvérsias, reducionismos, polaridades presentes nas produções que institucionalizam a PSE de média complexidade, não restritas ao plano das ideias, mas, decisivamente, aos projetos político-ideológicos em disputa.

Nesse contexto, a PSE de média complexidade foi avaliada pela perspectiva que identifica a correlação entre a reparação de direitos e o controle punitivo, com o intuito de explorar o sentido da contradição próprio das políticas sociais no capitalismo. O primeiro capítulo contemplou o debate sobre proteção social e as políticas sociais no contexto de reprodução e produção do modo de produção capitalista. A explanação inicial envolveu as protoformas das ações 
assistenciais nos países do capitalismo central, com destaque para as abordagens de Marx (2017) e Polanyi (2000). Na sequência, abordou a interpretação da formação social do capitalismo no Brasil, a partir da perspectiva de Caio Prado Júnior (1991; 2000), Florestan Fernandes (2000) e Octávio Ianni (2004).

Em adição, o contexto de fomento das primeiras políticas sociais brasileiras foi dimensionado, com ênfase nos contornos precursores da Assistência Social. Ao considerar a prerrogativa que situa a reprodução da violência como parte do processo de desenvolvimento das ações assistenciais, o estudo assinalou tendências que atravessam as diferentes versões institucionais da política, de modo a reconhecer a convergências das respostas protetivas e dos rebatimentos punitivos como elementos que conformam a trama assistencial no país. O tópico final do capítulo dialogou com as teses de Dardot e Laval (2016), com destaque para a interpretação da racionalidade neoliberal, debate necessário para reconhecer, no ordenamento atual da Assistência Social, as particularidades contemporâneas que dão sentido e forma ao binômio proteção e punição na PNAS/2004 - e na PSE de média complexidade em particular.

O segundo capítulo adensa o debate sobre o fenômeno da violência, a partir do diálogo com Misse (1999; 2014; 2016), aproximação que contribuiu para a distinção das definições de violência presentes nas normativas da PSE de média complexidade e do PAEFI. Ao demarcar um viés que a Política tende a operar, o estudo problematizou as disputas que envolvem o conceito de violência, que, de acordo com o autor, comparecem no próprio recorte do objeto - cuja prevalência remete a interpretações que privilegiam a abordagem da violência nas dinâmicas familiares e interpessoais. A abordagem do capítulo contempla, ainda, dados relativos ao fenômeno da violência no país, problematizando a perspectiva de reparação de direitos centrada na expectativa de autoproteção familiar.

O segundo tópico estabeleceu o diálogo com as obras de Adorno (1995) e Zaffaroni (2001; 2007), exercício que possibilitou o estudo de duas perspectivas analíticas distintas, as quais, entretanto, partem de pressupostos semelhantes - os limites do Estado democrático de direito - e convergem nas referências teóricas a exemplo da centralidade de Michael Foucault (2014) para ambos os autores. O exercício de análise agregou, assim, elementos para a avaliação do ciclo da Política de Assistência Social, ao introduzir camadas necessárias para a interpretação dos 
descaminhos punitivos da Política - tanto na tensa relação com o Sistema de Justiça, como na dualidade de práticas de proteção e correção nos próprios desígnios das ditas seguranças socioassistenciais.

O terceiro capítulo envolveu o percurso metodológico da pesquisa, cujo método, baseado na análise documental, objetivou analisar as concepções que qualificam o fenômeno da violência como campo de intervenção da Política de Assistência Social. O processo de investigação compreendeu a análise dos documentos e normativas que dimensionam o histórico, a concepção, a execução, a avaliação e a formação das equipes do PAEFI, enquanto diretivas institucionais que imprimem materialidade à proposta de acompanhamento familiar do CREAS.

Para tanto, foram selecionados documentos centrais para a análise dos pressupostos da PSE de média complexidade e do PAEFI, destacados dentre as normativas, planos, orientações técnicas, instruções, portarias e cadernos publicados pelo Executivo Federal - responsável pela gestão da Política de Assistência de Social, em âmbito nacional. O movimento de análise almejou identificar as categorias que delimitam o campo de intervenção do serviço de acompanhamento familiar do CREAS - o PAEFI, de modo a interpretar o recorte de violência que passou a ser formalmente atribuído à Assistência Social na atualidade.

A partir desse panorama, a investigação examinou as garantias socioassistenciais previstas como medidas de reparação de direitos no acompanhamento familiar da PSE de média complexidade, considerando que a premissa para o acompanhamento do PAEFI envolve as situações de risco social e pessoal, por violação de direitos. Em complemento, a pesquisa se voltou para a análise das expressões de violência incorporadas aos registros de atendimento e aos instrumentos de avaliação oficiais do SUAS, de modo a reconhecer os marcadores de violência que orientam a produção e a análise de dados da PSE de média complexidade, em especial do PAEFI.

Diante da formulação dos objetivos, geral e específicos do estudo, além da pergunta decisiva para a definição do método da pesquisa, a análise se voltou para a seleção dos documentos reconhecidos como fontes potenciais de informações no acerco documental da PNAS/2004. O período do estudo demarcou a efetivação da Política Nacional, em 2004, contemplando as resoluções e normativas publicadas 
até o ano de 2018, com o adendo da análise do documento do Programa de Combate ao Abuso e à Exploração Sexual de Crianças e Adolescentes, também conhecido como Sentinela, o qual data do ano de 2001, tendo em vista a imperiosa contextualização dos antecedentes institucionais do PAEFI.

Os tópicos subsequentes registraram os resultados do estudo que, detido aos recortes do fenômeno da violência que orientam o leque de garantias e medidas de reparação creditadas ao PAEFI, produziu dados a partir da análise dos documentos do ciclo de formulação, implementação e avaliação da Política, no período de 2004 a 2018, com a ressalva referente à normativa do Programa Sentinela.

Nesse contexto, a exposição dos resultados observou as fases do ciclo da Política de Assistência Social, com o intuito de demarcar a análise da violência nos documentos pertencentes ao mesmo escopo normativo - aqui definidos como: formulação, implementação, avaliação e formação continuada/capacitação. Portanto, a sistematização dos dados qualitativos considerou a transição temporal da abordagem ao fenômeno da violência nas publicações, processo que guarda particularidades, a depender da finalidade do documento, público ao qual se destina e do próprio processo de maturação política do SUAS no decorrer dos dois últimos decênios.

Por fim, a dissertação envolveu uma análise voltada para a proposição e devolutiva dos dados produzidos e reflexões elaboradas à comunidade científica e ao corpo de trabalhadores do SUAS da PCRJ. O estudo tem a expectativa de agregar elementos para a ampliação do repertório crítico das produções vinculadas ao executivo municipal da Política de Assistência Social e, até mesmo, incorporar considerações do estudo à agenda dos atores que participam do controle social da Política Municipal de Assistência Social - ainda que a conjuntura atual reforce correlações de forças adversas à defesa democrática dos direitos sociais. 
2.

\section{A Constituição Histórica da Assistência Social sob a Perspectiva do Binômio Proteção - Punição no Capitalismo.}

Os desígnios contemporâneos da Assistência Social brasileira, apreendidos a partir do marco institucional da PNAS/2004 e normativas posteriores, tornam flagrantes as contradições que atravessam a órbita dos direitos sociais e, para efeito da discussão aqui privilegiada, das garantias socioassistenciais. A PSE de média complexidade, analisada pelo ângulo que identifica a correlação entre a reparação de direitos e o controle punitivo, registra os limites e possibilidades que determinam o sentido das políticas sociais no processo de reprodução e atendimento das reivindicações e demandas da classe trabalhadora.

Num cenário em disputa, marcado por correlações de forças, antagonismos e polarizações no campo político, é imperativo situar a Assistência Social no marco dos direitos sociais, como tradução de uma política social, forjada nos limites do pacto de democratização do capitalismo - elementos que amparam distinções necessárias, num contexto em que a Política ascende como tradução literal de proteção social,

(...) um sistema de proteção social não é somente a justaposição de programas e políticas sociais, e tampouco se restringe a uma política social, o que significa dizer que a existência de políticas sociais em si não constitui um sistema de proteção social. O que configura um sistema de proteção social é o conjunto organizado, coerente, sistemático, planejado de diversas políticas sociais, financiado pelo fundo público e que garante proteção social por meio de amplos direitos, bens e serviços sociais (...). Tem como premissa o reconhecimento legal de direitos e a garantia de condições necessárias ao exercício do dever estatal para garanti-los (BOSCHETTI, 2016, p. 26).

A análise assumiu a concepção de políticas sociais enquanto resultado de relações contraditórias, determinadas pela luta de classes, pelo Estado e pelo grau de desenvolvimento das forças produtivas (BEHRING e BOSCHETTI, 2006; MOTA, 2008). Uma interpretação que reafirma o caráter ambíguo e paradoxal das políticas sociais, pois, ao passo que expressam conquistas civilizatórias, a partir do reconhecimento político e público de distintas expressões da "questão social", 
permitiram a socialização, por parte do Estado, dos custos gerais da produção com o capital, assim como o controle ideológico ${ }^{6}$, por meio de pactos e negociações entre classes, enquanto condição necessária para a preservação da hegemonia capitalista.

Se a compreensão da Assistência Social parte das contradições que as políticas sociais estabelecem na mediação entre a reprodução ampliada do capital e o reconhecimento político das demandas da classe trabalhadora, é possível demarcar, por extensão, os conflitos que particularizam sua configuração atual - tal como o trânsito das ações de média complexidade que vislumbram a reparação de direitos violados, do mesmo modo que consentem com intervenções pautadas pela lógica do enquadramento moral e punitivo das famílias em situação de pobreza.

Na Assistência Social contemporânea, implementada no Brasil, é possível reconhecer a reatualização de tensões que remontam às protoformas das ações assistenciais na Europa, bem como a histórica tendência de criminalização da questão social nos países periféricos - contextos que evidenciam a correlação entre estruturas protetivas e punitivas que atravessam o conjunto das políticas sociais e, em particular, a assistência. Ao contemplar diferentes contextos históricos, a discussão apresenta, como fio condutor da análise, a violência como parte do processo de desenvolvimento das ações assistenciais, seja pelo rito punitivo das primeiras iniciativas de proteção mobilizadas pelo Estado capitalista na Europa e no Brasil, tanto pela seleção de expressões que demarcariam um campo próprio de intervenção para a Política na atualidade.

\footnotetext{
${ }^{6}$ De acordo com a síntese de Chauí, "ideologia é um conjunto lógico, sistemático e coerente de representações (ideias e valores) e de normas ou regras (de conduta) que indicam e prescrevem aos membros da sociedade o que devem pensar e como devem pensar, o que devem valorizar e como devem valorizar, o que devem sentir e como devem sentir, o que devem fazer e como devem fazer. Ela é, portanto, um corpo explicativo (representações) e prático (normas, regras, preceitos) de caráter prescritivo, normativo, regulador, cuja função é dar aos membros de uma sociedade dividida em classes uma explicação racional para as diferenças sociais, políticas e culturais, sem jamais atribuir tais diferenças à divisão da sociedade em classes a partir das divisões na esfera da produção (...)" (2008, p. 110).
} 


\subsection{Histórico das Ações Assistenciais no Capitalismo.}

A discussão sobre as primeiras legislações assistenciais na Europa, sistematizadas a partir do diálogo com as obras de Marx (2017) e Polanyi (2000), parte da premissa que a Assistência Social admite, enquanto tendência histórica, uma relação simbiótica entre proteção e punição, na medida em que necessária ao processo de reprodução social e ao curso da imposição subjetiva do primado do trabalho. O debate recupera, ainda, a problemática desenvolvida por Boschetti (2016; 2018) sobre a inerente e insolúvel tensão entre assistência social e trabalho na sociedade capitalista, além da referência ao Estado Social, tomado como estratégico para explicitar a regulação econômica e social efetivada a partir do capitalismo tardio (MANDEL, 1982).

Ao estabelecer como ponto de partida a tensão entre assistência social e trabalho, faz-se necessário recuperar a interpretação de Marx (2017) sobre as diferentes formas de existência da superpopulação relativa ${ }^{7}$ - flutuante, latente e estagnada. Para o autor, todo trabalhador a integra durante o período em que está parcial ou absolutamente desocupado. Em linhas gerais, a superpopulação relativa, sob a forma flutuante, é ilustrada pelo movimento identificado nos centros da indústria moderna do século XIX, nos quais os trabalhadores ora eram repelidos, ora atraídos, de modo que o número de trabalhadores ocupados se elevava, ainda que em proporção decrescente à escala de produção (MARX, 2017).

Para ilustrar o segmento latente, Marx recupera a forma como a produção capitalista se apoderou da agricultura, destacando que a demanda da população trabalhadora rural decrescia em termos absolutos na mesma proporção em que se expandia a acumulação do capital em funcionamento nessa esfera. Assim, uma parte da população rural se encontrava continuamente em vias de se transferir para o proletariado urbano e à espreita de circunstâncias favoráveis a essa transição. Para

\footnotetext{
7 Para Marx, "a acumulação capitalista produz constantemente, e na proporção de sua energia e seu volume, uma população trabalhadora adicional relativamente excedente, isto é, excessiva para as necessidades médias de valorização do capital e, portanto, supérflua" (2017, p. 705). Em complemento, "mas se uma população trabalhadora excedente é um produto necessário da acumulação ou do desenvolvimento da riqueza, com base capitalista, essa superpopulação se converte, em contrapartida, em alavanca da acumulação capitalista, e até mesmo numa condição de existência do modo de produção capitalista. Ela constitui um exército industrial de reserva disponível, que pertence ao capital de maneira tão absoluta como se ele o tivesse criado por sua própria conta" (MARX, 2017, p. 707).
} 
o autor, essa fonte da superpopulação relativa fluía continuamente, mas seu fluxo constante para as cidades implicava a existência, no próprio campo, de uma contínua superpopulação latente, cujo volume se tornava aparente quando os canais de escoamento eram liberados em toda sua amplitude (MARX, 2017).

A categoria denominada estagnada constitui uma parte do exército ativo de trabalhadores, mas com ocupação totalmente irregular. A superpopulação relativa estagnada proporciona ao capital um depósito infindável de força de trabalho disponível. Ressalta que sua condição de vida é inferior ao nível médio normal da classe trabalhadora, condição que a torna uma base ampla para determinados ramos de exploração do capital - "suas características são o máximo de tempo de trabalho e o mínimo de salário" (MARX, 2017, p. 718).

Ao final da exposição, Marx afirma que o pauperismo constitui o sedimento mais profundo da superpopulação relativa, sendo formado por três categorias: os aptos ao trabalho; a segunda é composta por órfãos e crianças indigentes, candidatos ao exército industrial de reserva; e a terceira seriam os ditos degradados, maltrapilhos, incapacitados para o trabalho (MARX, 2017). Em síntese,

\begin{abstract}
O pauperismo constitui asilo para inválidos do exército trabalhador ativo e o peso morto do exército industrial de reserva. Sua produção está incluída na produção da superpopulação relativa, sua necessidade na necessidade dela, e juntos eles formam uma condição de existência da produção capitalista e do desenvolvimento da riqueza. (MARX, 2017, p. 719)
\end{abstract}

Em complemento, Marx (2017) sentencia as oposições que ilustram a lei geral e absoluta da acumulação capitalista, ao tomar como premissa que o avançar da riqueza social e do capital em funcionamento, a expansão do proletariado e a força produtiva de seu trabalho, determinam a própria ampliação do exército industrial de reserva. Portanto, na lei geral da acumulação capitalista

(...) a acumulação da miséria correspondente à acumulação do capital (...) a acumulação da riqueza num polo é, ao mesmo tempo, a acumulação da miséria, o suplício do trabalho, a escravidão, a ignorância, a brutalização e a degradação moral no polo oposto, isto é, do lado da classe que produz seu próprio produto como capital. (MARX, 2017, p. 721)

O contraste que Marx elabora coloca em evidência o caráter antagônico da acumulação capitalista, a qual justifica a coexistência do acúmulo da riqueza e da 
miséria como pressupostos. No decorrer da exposição, exercita a ilustração da lei geral da acumulação capitalista, dimensionando indicadores do crescimento exponencial da riqueza na Inglaterra, no período de 1846 a 1866, apenas comparado ao avanço da miséria do proletariado industrial e dos trabalhadores agrícolas no mesmo período. Ao retratar a expansão da lista oficial de indigentes, o autor versa sobre o pauperismo oficial, enquanto “(...) parcela da classe trabalhadora que perdeu sua condição de existência - a venda da força de trabalho - e que vegeta graças a esmolas públicas”. (MARX, 2017, p. 728)

Nesse ponto da argumentação, é possível retomar os nexos entre o trabalho e assistência social, uma vez que a condição da superpopulação relativa e, consequentemente, do pauperismo retoma a centralidade do trabalho e sua possibilidade de realização na escala de produção que se estabelecia à época. Ao definir as categorias que conformavam o pauperismo, Marx faz menção à capacidade laboral como métrica, uma vez que a distinção se apresenta entre os aptos ao trabalho, segmentos geracionais desprotegidos e os reconhecidos incapacitados para o trabalho. Ao enunciar as condições de sobrevivência do proletariado agrícola britânico ${ }^{8}$, preservadas pelas mencionadas esmolas públicas, o autor expõe as penalidades que acompanham a submissão ao imperativo do trabalho.

A problematização de Boschetti (2016), ao analisar as legislações fabris e assistenciais apresentadas por Marx, reafirma que assistência social e trabalho se conjugam na regulação das relações sociais capitalistas como esferas antagônicas, ao prever a assistência social mínima aos incapazes e trabalho forçado aos capacitados em desempenhá-lo. Para a autora,

(...) é possível considerar, portanto, que desde as origens da acumulação primitiva, a participação das protoformas da assistência social na mediação do processo de reprodução social era mais diretamente relacionada à superpopulação relativa estagnada em situação de pauperismo e incapacitada ao trabalho (BOSCHETTI, 2016, p. 91)

8 Marx afirma que "em nenhuma outra parte o caráter antagônico da produção e da acumulação capitalista se manifesta mais brutalmente do que no progresso da agricultura inglesa e no retrocesso do trabalhador agrícola inglês" (MARX, 2017, p. 746). 
Ao discorrer sobre a acumulação primitiva, Marx sentencia que "a relação capitalista pressupõe a separação entre os trabalhadores e a propriedade das condições da realização do trabalho" (MARX, 2017, p. 786). Em consequência, o processo que estabelece a relação capitalista transforma em capital os meios sociais de subsistência e de produção e converte os produtores diretos em trabalhadores assalariados. O intitulado segredo da acumulação primitiva não é, segundo o autor, mais do que o processo histórico de separação entre produtor e meio de produção "ela aparece como primitiva porque constitui a pré-história do capital e do modo de produção que lhe corresponde" (MARX, 2017, p. 786).

Marx enfatiza, ao discorrer sobre a história da acumulação primitiva, o impacto provocado pelo despojamento súbito e violento dos meios de subsistência sofrido pelos produtores rurais e camponeses, que provocou a entrada destes no mercado de trabalho como proletários absolutamente livres (MARX, 2017). Para o autor, a expropriação da terra constituiu a base de todo o processo, embora advirta que, a depender do período histórico, tenha assumido características distintas. A ressalva é necessária para justificar a análise centrada na Inglaterra, país que, segundo o qual, a expropriação se apresentou em sua forma clássica.

Com o intuito de elucidar as transições históricas analisadas por Marx, cabe demarcar a passagem do texto em que o autor anuncia que o prelúdio da revolução, que viabilizou o desenvolvimento das bases do modo de produção capitalista, ocorreu no último terço do século XV e nas primeiras décadas do século XVI. Nesse sentido, aponta que o impulso do processo de expropriação violenta das massas populares, no século XVI, foi provocado pela Reforma Protestante, marcado pela apropriação dos bens da Igreja Católica. Como proprietária de grande parte do solo inglês, a Igreja sofreu a dissolução dos monastérios, dos bens eclesiásticos, além da perda das propriedades destinadas aos camponeses empobrecidos, lançando, nas palavras de Marx, a entrada de seus moradores no proletariado (MARX, 2017).

Um exercício de síntese permite destacar, ainda, dois pontos que Marx descreveu como cruciais nos processos de expropriação: a Revolução Gloriosa que desencadeou, em escala definida como colossal, a apropriação fraudulenta do patrimônio do Estado; as leis para o cercamento da terra comunal, definidas como 
um golpe de Estado parlamentar para transformar essas terras em propriedades de fundiários privados. Além dos últimos registros, Marx conclui que:

O roubo dos bens da Igreja, a alienação fraudulenta dos domínios estatais, o furto da propriedade comunal, a transformação usurpatória, realizada com inescrupuloso terrorismo, da propriedade feudal e clânica em propriedade privada moderna, foram outros tantos métodos idílicos da acumulação primitiva. Tais métodos conquistaram o campo para a agricultura capitalista, incorporaram o solo ao capital e criaram para a indústria urbana a oferta necessária de um proletariado inteiramente livre. (MARX, 2017, p. 804)

Com a narrativa do ciclo das expropriações, Marx detalha a violência que permeou a retirada dos meios de subsistência da então recente massa de proletários, bem como aponta os impactos para o modo de vida, abruptamente modificado em razão da disciplina imposta pela manufatura emergente à época. $\mathrm{O}$ autor ponderou os efeitos subjetivos da submissão ao trabalho, considerando se tratar de uma imposição que condicionou o sentido da liberdade ao processo de acumulação. E, por assim dizer, alterou, de forma singular, o próprio sentido da existência humana, agora determinada para e pelo trabalho.

Ao reconhecer o difícil ajuste às condições impostas pelos novos arranjos da organização do trabalho, Marx assinala a conversão massiva do nascente proletariado “(...) em mendigos, assaltantes, vagabundos, em parte por predisposição, mas na maioria dos casos por força das circunstâncias” (MARX, 2017, p. 806). A justificativa da repressão mobilizou um aparato de leis voltado para os "delinquentes voluntários" (idem, p. 806), envolto no ideário que legitimava o trabalho, ainda que determinado por condições que já não mais existiam (MARX, 2017).

O autor definiu como legislações sanguinárias o estatuto legal contra a vagabundagem, cujo direcionamento sustenta a capacidade laborativa como limiar para a punição ou proteção. Na concepção de Boschetti (2016), tais legislações expressam originalmente a tensão entre trabalho e ajuda assistencial, a partir da oposição entre os pobres capazes àqueles incapazes para o trabalho. $\mathrm{O}$ tenso vínculo entre assistência e trabalho foi determinante para a admissão do exercício da liberdade nos termos da venda da força de trabalho em troca de salário, além de forjar o disciplinamento necessário ao regime do trabalho nos moldes do 
capitalismo - assegurados por meio de ajudas pontuais, como pelo açoite, do ferro em brasa e da tortura (MARX, 2017).

Marx destaca as principais medidas das legislações sanguinárias, caracterizadas a partir das escassas coberturas e das severas punições aplicadas. Em 1530, “(...) mendigos velhos e incapacitados para o trabalho recebem uma licença para mendigar. Em contrapartida, açoitamento e encarceramento para os vagabundos mais vigorosos". (MARX, 2017, p. 806). No ano de 1547, a legislação prevê que “(...) quem se recusar a trabalhar deverá ser condenado a se tornar escravo daquele que o denunciou como vadio". (idem, p. 806).

No período de 1572, “(...) mendigos sem licença e com mais de 14 anos de idade devem ser severamente açoitados e ter a orelha marcada a ferro, caso ninguém queira tomá-los a serviço por 2 anos" (idem, p. 807). Em complemento, na vigência de Jaime I, Marx sublinhou que: “(...) alguém que vagueie e mendigue será declarado um desocupado e vagabundo. (...) serão açoitados em público e encarcerados, na primeira ocorrência, por 6 meses, e, na segunda, por 2 anos" (idem, p.808).

O panorama retratado dimensiona a submissão imposta às populações que, violentamente, sofreram perdas de ordem material, a considerar a expulsão das terras, e demais danos do ciclo de expropriações, como os impactos subjetivos, a partir da concepção capitalista da produção como um processo natural e inevitável ao curso do desenvolvimento humano. Para Marx (2017), no evolver da produção capitalista, a condição de dependência do trabalhador é forjada e naturalizada - seja pelos ritos punitivos das legislações assistenciais, como pela coerção muda exercida pelas relações econômicas.

Nesse ponto da exposição, Marx sublinha, como um momento essencial da acumulação primitiva, o desenvolvimento de uma classe de trabalhadores que “(...) por educação, tradição e hábito, reconhece as exigências do modo de produção capitalista como leis naturais e evidentes por si mesmas" (idem, p. 808). É possível reconhecer que o trânsito das medidas assistenciais à lógica do trabalho incontingente, foi decisivo para, nas palavras de Marx, permitir o curso usual das coisas, onde se tornou possível confiar o trabalhador às leis naturais da produção, isto é, “(...) à dependência em que ele mesmo se encontra em relação ao capital, 
dependência que tem origem nas próprias condições de produção e que por elas é garantida e perpetuada" (idem, p.809).

Marx (2017) sinaliza que a burguesia emergente, já no contexto de consolidação da organização capitalista da produção, requisitou e mobilizou a força do Estado para controlar o salário e a correlata condição de dependência do trabalhador. Em sua interpretação, a constante ampliação de uma superpopulação relativa mantém a lei da oferta e da demanda de trabalho e, consequentemente, "o salário nos trilhos convenientes às necessidades de valorização do capital" (idem, p.808).

Ao recuperar a síntese de Marx (2017) sobre a violenta criação do proletariado inteiramente livre, da disciplina sanguinária que os condicionou à relação assalariada, da hedionda ação do Estado que, por meios policiais, ampliou a exploração do trabalho e, em consequência, a acumulação do capital, é possível reconhecer, a despeito do distanciamento histórico, relevantes aspectos da regulação estatal contemporânea.

Para efeito da discussão, aqui proposta, a análise se detém à relação de atração e rejeição entre assistência social e trabalho, mediada, decisivamente, pela intervenção do Estado. Ainda que os marcos da regulação estatal se diferenciem em aspectos conjunturais e espaciais, cabe a problematização dos elementos desta atuação que salvaguardam as regras necessárias para a reprodução das relações de produção e valorização do capital e, a depender da correlação de forças, demarcam garantias representativas para classe trabalhadora.

O Estado preserva sua condição estratégica, na qualidade de árbitro que confere legitimidade e preserva as regras do jogo capitalista. No campo econômico, regulamenta a sujeição do trabalho à lógica de valorização incessante do capital, enquanto que na esfera das relações, exerce o controle que disciplina a reprodução social, necessária ao enquadramento moderno, condição onde os sujeitos são atravessados e definidos pela lógica do mercado, dada o intenso processo de mercantilização dos elementos necessários à vida (FONTES, 2011).

Nesse contexto, os contornos da relação entre trabalho e assistência social são ressaltados, ao se considerar a perspectiva de ajuste e disciplinamento creditado às estruturas assistenciais, num contexto em que urge o ordenamento pautado na alienação de bens públicos, transformados em mercadorias e nichos de investimento 
privado - tendências contemporâneas que se colocam como renovadas estratégias de acumulação de capital.

O controle de outrora, detido à sublimação do trabalho, hoje é voltado para a admissão da disponibilidade irrestrita da força de trabalho, conversão na qual os sujeitos assumem o protagonismo das necessidades de sua reprodução, assim como daqueles a eles vinculados - em outras palavras, a assistência assume mecanismos de ajuste da pobreza ao ideário do mercado das proteções, em franca substituição à perspectiva de proteção social pública, afiançada pelo Estado.

O percurso da análise ao se voltar para a discussão dos processos de mercantilização da vida contemporânea, exige um ponto de retorno para a história social do século XIX, que, na perspectiva de Polanyi (2000), é determinado pela lógica do sistema de mercado. Depreende-se que a sociedade de mercado, em especial o padrão consolidado no século XIX, é decisiva para análise dos parâmetros da intervenção do Estado - direcionados para preservar o marco regulatório do trabalho, instituído sob o signo da sociabilidade burguesa, como aqueles destinados ao anteparo necessário para a reprodução e atendimento das demandas da classe trabalhadora.

Tem-se a pretensão de articular a interpretação dos princípios da economia de mercado com a lógica que orienta a regulação estatal, os quais, a partir de distintas referências teóricas, mobilizam elementos de convergência para a interpretação dos vieses protetivos e punitivos presentes nos arranjos institucionais da Política de Assistência Social. Trata-se de um movimento de análise que admite os riscos que tal diálogo oferece, considerando as distintas matrizes analíticas implicadas e possíveis omissões históricas, a considerar processos que arrolam os séculos XIX, XX e XXI.

A perspectiva de Polanyi (2000) permite a compreensão da ascensão (e ruína) do ideário do mercado auto regulável no século XIX, ao ponderar os efeitos sociais decorrentes da generalização das transações monetárias, que subverteram a motivação da subsistência para a motivação do lucro. Para o autor, “(...) a produção das máquinas numa sociedade comercial envolve uma transformação que é a da substância natural e humana da sociedade em mercadorias" (POLANYI, 2000, p. 61). 
Ao destacar as proposições de Polanyi e, por conseguinte, a análise da história social do XIX, a argumentação recupera o período de 1795 a 1834, que assinala a vigência da Speenhamland Law na Inglaterra. As décadas em questão representam, na perspectiva de Polanyi, um período de inflexão, quando comparado com a estrutura das leis dos pobres predominantes até o século XVIII - descritas no tópico anterior. Segundo o autor, sob a doutrina da lei elisabetana, os pobres eram obrigados a trabalhar com qualquer salário e somente aqueles que não conseguiam ocupações tinham direito à assistência social - “(...) nunca se pretendeu e nem se concedeu qualquer assistência sob a forma de abono salarial" (POLANYI, 2000, p. 101).

Denominada como sistema de abonos, a Speenhamland Law assegurava a concessão de complementos, em aditamento aos salários, de acordo com a escala do preço do pão. Com efeito, a Lei afiançava ao pobre uma renda mínima independente dos proventos auferidos na relação de trabalho. Para o autor, a Speenhamland Law introduziu uma inovação social e econômica, medida que avalizou o "direito de viver" (idem, p.100) e, em consequência, evitou o estabelecimento de um mercado de trabalho competitivo à época.

Durante a vigência do dito sistema de abonos, o indivíduo percebia assistência, mesmo quando empregado, caso seu salário fosse menor do que a renda familiar definida pela tabela da Speenhamland. Na concepção de Boschetti (2016), essa legislação é considerada a primeira iniciativa de estabelecimento legal de um "benefício assistencial monetário" aos pobres, independente do exercício do trabalho remunerado. Assinala, em concordância com Polanyi (2000), que tal iniciativa protegia o direito à vida e agiu como forma de resistência à implantação da sociedade de mercado no século XIX.

Polanyi (2000) registrou que, em poucos anos, a produtividade do trabalho começou a declinar, ocasionando a estagnação dos salários. A resistência ao sistema de abonos o identificava como um obstáculo à nova economia capitalista, na medida em que a imposição do sistema de salários dependeria da abstração do "direito de viver" (idem, p.101). Com as prerrogativas da legislação, a classe média inglesa alertava que “(...) ninguém trabalharia por um salário se pudesse sobreviver sem fazer nada" (idem, p. 101). Na interpretação de Polanyi, no decorrer da vigência da Speenhamland, a sociedade inglesa debatia duas influências opostas: 
(...) a que emanava do paternalismo e que protegia a mão-de-obra dos perigos de um sistema de mercado e a que organizava os elementos de produção, inclusive a terra, sob um sistema de mercado, afastando a gente comum do seu status anterior, compelindo-a a ganhar a vida oferecendo seu trabalho à venda enquanto, ao mesmo tempo, privava esse trabalho do seu valor mercado (POLANYI, 2000, p. 103)

Nessa passagem, o autor constata a incompatibilidade entre o sistema de salários e o de abonos - "a impossibilidade do funcionamento de uma ordem capitalista enquanto os salários fossem subsidiados por fundos públicos" (idem, p.104). Diante dos entraves provocados pela Speenhamland Law, cujo movimento se destinou a impedir ou minorar a proletarização do homem comum, em 1834 foi decretada sua revogação pela Poor Law Reform. Em linhas gerais, a reforma representou o término das obstruções à efetivação do mercado de trabalho.

Ao abolir as garantias do "direito de viver", a também conhecida como Nova Lei dos Pobres (BOSCHETTI, 2016), determinou a prerrogativa do trabalho como garantia exclusiva de acesso à renda. A recente doutrina relegou a assistência aos pobres aos domínios da filantropia, além de reatualizar os preceitos das leis assistenciais punitivas, que determinavam a obrigatoriedade de trabalhos forçados aos tidos como capazes e a assistência aos inválidos nas pífias estruturas dos albergues.

No entanto, segundo Polanyi (2000), as atrocidades burocráticas perpetradas contra os pobres, após a abolição da Speenhamland, são consideradas, ironicamente, como quase nulas, se contrastadas aos efeitos da mais potente das instituições modernas - o mercado de trabalho. Prossegue, ao sentenciar que a fonte de perigo fora substituída, não pela ausência, mas pela presença de um mercado de trabalho competitivo - "se a Speenhamland significava a decomposição da imobilidade, agora o perigo era a morte pela exposição" (idem, p. 106).

Em complemento, Polanyi (2000) sinaliza que a extinção da Speenhamland data a afirmação do mercado de trabalho competitivo na Inglaterra, contexto que consolida o capitalismo industrial como sistema social e, portanto, o primado do trabalho como fonte única e exclusiva de acesso à renda - "não é exagero dizer que história social do século XIX foi determinada pela lógica do sistema de mercado propriamente dito, após a liberação da Poor Law Reform Act. O ponto de partida dessa dinâmica foi a Speenhamland Law” (idem, p. 106). 
A injunção das regras do sistema de salários baseado no livre mercado deflagrou, segundo a leitura de Polanyi, um movimento de autoproteção da sociedade, pautado pelas leis fabris e uma legislação social. Nesse ponto, o autor adentra na discussão do pauperismo, reportado como um dos paradoxos que a sociedade industrial impôs ao homem moderno - "o pauperismo fixou a atenção no fato incompreensível de que a pobreza parecia acompanhar a abundância" (idem, p. 107). Embora o argumento problematize o pauperismo, cabe o destaque da apreensão distinta das análises vinculadas à teoria crítica marxista.

Para Polanyi (2000), dentre outros aspectos divergentes, se a economia de mercado representou uma ameaça para os componentes humanos do tecido social - "o que mais se poderia esperar senão que uma ampla gama de pessoas exercesse a maior pressão no sentido de obter alguma espécie de proteção?” (idem, p. 182). Ao refutar a perspectiva de classe, o autor argumenta que o dito movimento protetor consistiu num movimento da sociedade como um todo - "parece razoável agrupar o relato do movimento protetor não em torno de interesses de classe, mas em torno das substâncias sociais ameaçadas pelo mercado" (idem, p. 196).

No marco da tradição marxista, tal como explicitado no tópico anterior, o pauperismo traduziu o inédito fenômeno do crescimento exponencial da pobreza proporcional à capacidade de produção social de riquezas. De acordo com Netto, o fenômeno da pobreza “(...) acentuada e generalizada no primeiro terço do século XIX - o pauperismo - aparecia como nova precisamente porque ela se produzia pelas mesmas condições que propiciavam os supostos, no plano imediato, da sua redução e, no limite, da sua supressão" (2001, p. 43). As análises dos desdobramentos anotam as discordâncias entre os autores, considerando que a matriz crítica marxista reconhece as reações dos segmentos pauperizados como situações limite, ameaças concretas às instituições vigentes.

Ao questionar as contrarreações como mobilizações de classes específicas, Polanyi confronta as interpretações que situam a exploração econômica como o veículo da destruição, ao reportar a degradação cultural como um “(...) ferimento letal infligido às instituições nas quais a existência social está inserida" (POLANYI, 2000, p.191). Ao desenvolver uma análise institucional das décadas seguintes à revogação da Speenhamland, Polanyi (2000) sublinha o avanço do mercado nas esferas que afetam o homem, a natureza e a organização produtiva, contexto que 
incorreu num movimento de autopreservação generalista, posto que afeito à defesa da sociedade.

A compreensão de Netto (2001) reporta a Revolução de $1848^{9}$ como um "divisor de águas", na medida em que se encerra o ciclo progressista da ação de classe da burguesia e, em consequência, finda a possibilidade de se estabelecer nexos entre economia e sociedade e do próprio desenvolvimento capitalista e pauperização. Aqui se coloca o núcleo do debate marxista, o qual identifica como resultante da Revolução de 1848 a passagem, na dimensão histórico-universal, do proletariado da condição de classe em si a classe para si (NETTO, 2001) - ascensão que permitiu transpor a conceituação do pauperismo como um fenômeno pontual para a designação como "questão social".

As vanguardas trabalhadoras acederam, no seu processo de luta, à consciência política de que a "questão social" está necessariamente colada à sociedade burguesa: somente a supressão desta conduz à supressão daquela. O desenvolvimento capitalista produz, compulsoriamente, a "questão social" diferentes estágios capitalistas produzem diferentes manifestações da "questão social"; esta não é uma sequela adjetiva ou transitória do regime do capital: sua existência e suas manifestações são indissociáveis da dinâmica específica do capital tornado potência dominante. A "questão social é constitutiva do desenvolvimento do capitalismo. Não se suprime a primeira conservando-se o segundo (NETTO, 2001, p. 45)

Afiançar o debate da "questão social", a partir do referencial crítico que, a despeito do avanço conservador, ainda orienta a produção teórica no Serviço Social, recupera a problemática da pesquisa, a qual identifica um cariz punitivo imbricado nas garantias socioassistenciais da PSE de média complexidade. O processo mistificador da "questão social” naturaliza suas manifestações, convertendo-a como objeto de ações moralizadoras - o que Netto (2001) designou como a reforma moral

9 O autor pontua que "a inflexão histórica de 1848, circunscrevendo o espaço sociopolítico da burguesia e explicitando a natureza de classe da sua dominação, selou a sorte do bloco cultural progressista: suas conquistas foram apropriadas pelos revolucionários e isso bastou para que os representantes da ordem rechaçassem a sua influência. A partir daí, os ideólogos burgueses, para responder ao movimento operário e combater a perspectiva da revolução, recorrem cada vez mais ao arsenal de ideias contidas nas propostas restauradoras e românticas. Como se vê, a evolução do pensamento sobre a sociedade burguesa tem em 1848 um divisor de águas: desde então, ele se fratura em dois campos opostos - o que se vincula à revolução e o que contrasta com ela. Mesmo que este não seja um corte absoluto e que o desenvolvimento de ambos se conecte com insuspeitada frequência, aqueles dois campos delimitam o terreno das grandes matrizes da razão moderna: a teoria social de Marx e o pensamento conservador, produto da conjunção dos veios restauradores e românticos" (NETTO, 2006, p. 14). 
do homem e da sociedade. Portanto, a PSE de média complexidade ao demarcar a relação familiar como a instituição que vivencia e, mutuamente, é responsável por reproduzir os riscos que determinam as violações de direitos, opera a naturalização e supressão do conflito de classes e demais desigualdades estruturantes numa Política destinada ao atendimento e reparação de múltiplas expressões da "questão social".

Não obstante, a recomposição histórica elaborada por Polanyi é de suma relevância para o debate da pesquisa, considerando o embasamento teórico que possibilitou a identificação do trabalho assalariado como princípio normatizador da economia de mercado. Para tanto, o autor dimensionou o binômio da proteção e da punição como atributos da equação que viabilizou a generalização das leis do mercado, cuja extensão confluiu em ameaças aos aspectos tomados como vitais da experiência humana: ao homem, à natureza e à organização produtiva ${ }^{10}$. Elementos que reforçam a tensão entre trabalho e assistência social e direcionam a discussão para as lutas que impuseram limites à configuração do trabalho livre e conformaram as regulamentações sociais e do trabalho no século XX.

A análise se detém, portanto, ao contexto histórico que remonta ao contra movimento protecionista, segundo a ótica de Polanyi, ou às lutas pela "jornada normal de trabalho", a partir da obra de Marx - leituras apropriadas como referências para a conformação das políticas de proteção social nos países capitalistas centrais. Para efeito do debate, aqui privilegiado, cabe ressaltar o primado do trabalho como atributo central das garantias legitimadas, considerando a consagração de direitos provenientes da relação assalariada.

A partir desse ponto, faz-se necessário retomar o diálogo com Boschetti (2016), para a qual, o capitalismo, diante da impossibilidade de garantir o direito ao trabalho como uma premissa universal, estabeleceu, como alternativa para a reprodução da superpopulação relativa e as necessidades constantes de acumulação do capital, “(...) a garantia de direitos condicionados ao trabalho para os trabalhadores capazes, necessários à sua reprodução em momentos de incapacidade

10 Para Polanyi, "o mercado de trabalho competitivo atingiu o possuidor da força de trabalho, isto é, o homem. O comércio livre internacional foi basicamente uma ameaça a maior indústria dependente da natureza, isto é, a agricultura. O padrão-ouro ameaçou as organizações produtivas que dependiam do movimento relativo dos preços para o seu funcionamento. Os mercados se desenvolveram, em cada uma dessas áreas, o que implicou uma ameaça latente para a sociedade em alguns dos aspectos mais vitais da sua existência" (2000, p. 196). 
para o trabalho" (idem, p.97). Com efeito, os direitos foram instituídos contemplando a oposição capacidade/incapacidade para o trabalho - princípio que orientou a construção do Estado Social na maioria dos países capitalistas centrais e periféricos, guardadas as particularidades históricas e sociais que materializaram experiências concretas distintas (BOSCHETTI, 2016; 2018).

O Estado Social, aqui discutido pela ótica de Boschetti (2016; 2018), é tomado como referência para explicitar a regulação econômica e social efetivada a partir do capitalismo tardio (MANDEL, 1982), enfatizando que o Estado, ao assumir um viés social por meio dos direitos implementados pelas políticas sociais, não prescinde de sua natureza capitalista e, tampouco, se constitui como uma instância neutra de produção de bem-estar (BOSCHETTI, 2016). A autora situa os sistemas de proteção social públicos a partir da regulação estatal que se materializa após a grande crise de 1929 e se expande após a Segunda Guerra Mundial. Destaca que a formulação dos sistemas de proteção social ascendeu como componente decisivo, dentre as medidas denominadas anticrise do período (BOSCHETTI, 2016).

As referências históricas remontam, necessariamente, a experiência dos países capitalistas da Europa Ocidental, em um contexto de produção em série, direcionado ao consumo de massa - características do regime fordista. Nesse contexto, as políticas sociais, organizadas em sistemas de proteção social, asseguraram o expressivo crescimento econômico identificado entre a década de 1940 e a década de 1970, conjuntura que inaugura os termos do pleno emprego, além do amplo acesso a serviços públicos de educação, saúde, previdência e assistência social (BEHRING e BOSCHETTI, 2006; BOSCHETTI, 2016). Em síntese,

(...) o que se denomina Estado Social capitalista é o Estado que, no capitalismo tardio, assume importante papel na regulação das relações econômicas e sociais, tendo por base a constituição de um sistema de proteção social de natureza capitalista, assentado em políticas sociais (...) (BOSCHETTI, 2016, p. 28).

Ao compartilhar tal assertiva, sustenta-se a definição de Estado Social para designar a regulação econômico-social por meio de políticas sociais, a qual incorpora atributos sociais, ao passo que preserva sua natureza essencialmente capitalista. Com efeito, registra-se que o uso da categoria social não atribui qualquer 
condição valorativa ao Estado, cujo intuito reside na qualificação da ação do Estado no capitalismo tardio (BOSCHETTI, 2016).

A partir da década de 1970, o Estado Social é marcado por inflexões, considerando as dificuldades crescentes na valorização do capital, notadamente influenciada pelo contexto de crise e estagnação dos lucros. Com efeito, as disputas em torno das taxas de mais-valia tornam-se explosivas, com indicativos da restrição da redistribuição horizontal de frações do trabalho excedente e do trabalho necessário por meio das políticas sociais (BOSCHETTI, 2018). Boschetti (2018) defende que as transformações do Estado Social marcaram um processo de derruição de suas tendências universalistas.

Em adição, no que se refere ao Estado Social nos países do capitalismo periférico e dependente, com traços restritos e limitados desde sua gênese, a autora pontua que a ofensiva burguesa recolocou bárbaras formas de superexploração da força de trabalho. Tal cenário é decisivo para a análise das projeções e materialidade do sistema de proteção social no Brasil, em que pese o avanço normativo dos direitos sociais no período da redemocratização, cujo ápice denota a consolidação das políticas de seguridade social na Constituição Federal de 1988. Antes, porém, faz-se necessário explorar o histórico do surgimento e desenvolvimento da política social e da assistência social, em particular, tendo em vista as peculiaridades da formação do capitalismo no Brasil, quando contrastado com a experiência dos países do capitalismo central.

\subsection{Histórico da Assistência Social no Brasil.}

A trajetória de maturação da política social no Brasil registra distinções temporais e particularidades de um país situado na periferia do capitalismo mundial, em contraste com o panorama, apresentado no tópico anterior, das nações europeias, em especial a Inglaterra. Para recompor esse percurso, necessário para a identificação dos antecedentes históricos da Assistência Social, a discussão retoma as bases do capitalismo nacional, a partir dos elementos que caracterizam a transição escravocrata para o trabalho livre e a árdua pactuação por direitos e garantias de proteção social. 
Dentre os teóricos do campo marxista, a interpretação da formação social do capitalismo brasileiro possui como uma das principais referências as contribuições de Caio Prado Jr. Para efeito da discussão, por ora encadeada, a análise privilegiou o diálogo com Ianni (2004), Behring e Boschetti (2006), autores que compartilham a tese defendida por Caio Prado relativa aos processos que sintetizam as raízes históricas do Brasil contemporâneo - o sentido da colonização, o regime escravo e o desenvolvimento desigual e combinado. Segundo Ianni (2004), são processos que se influenciam mutuamente, temáticas que orientam o resgate do passado para desvendar traços constitutivos do presente.

De acordo com Behring e Boschetti (2006), a análise do sentido da colonização no Brasil destaca a complexa articulação do mercado mundial com os movimentos internos da economia e da sociedade brasileira. No evolver dos séculos XVI ao XIX, o processo de colonização serviu à acumulação originária nos países centrais. Ianni (2004) afirma que a colonização se configura como uma temática constante nos escritos de Caio Prado, para o qual a lógica de subordinação e dependência ao mercado mundial permaneceu inalterada nos períodos do Brasil Colônia, Império e República, ainda que os determinantes dessas relações tenham sofrido modificações, a depender das distintas conjunturas. Caio Prado ${ }^{11}$ ressalta que "o Brasil viveu no curso de toda a sua história, e ainda vive, em função das flutuações de mercados longínquos que podem fazer a sua fortuna ou miséria, sem que ele nada possa dizer na matéria" (PRADO Jr., 1954, p. 43 apud IANNI, 2006, p. 56).

Em relação ao regime escravo, Ianni (2004) registra o peso dos séculos de escravatura, determinante para a organização do trabalho e vida, economia, política e cultura. Para o autor, em convergência com Caio Prado, o escravismo produziu um universo de valores, padrões, ideias, doutrinas, modos de ser, pensar e agir. Em síntese, assinala que a bússola da sociabilidade e do poder, da cultura e ideologia estava assinalada pelo regime escravo - traços constitutivos do racismo estrutural que atravessa e conforma distintas relações no passado e presente, definindo lugares, posições e estigmas sociais.

${ }^{11}$ PRADO Jr, C. Diretrizes para uma política econômica brasileira. São Paulo: Gráfica Urupês, 1954. 
O conceito do desenvolvimento desigual e combinado, a partir da leitura de Ianni (2004), caracteriza a formação social brasileira, a qual se aproxima de um caleidoscópio de variadas épocas, formas de vida e trabalho, modos de ser e pensar. O Brasil capitalista, industrializado, urbanizado, convive com inúmeros momentos pretéritos, em razão da via não clássica do processo de transição para o capitalismo. Para Caio Prado, a adaptação brasileira ao capitalismo se deu pela lenta substituição do trabalho escravo para o trabalho livre nas grandes unidades rurais, numa complexa articulação de progresso - a adaptação ao capitalismo - e conservação, dada a permanência de importantes elementos da estrutura colonial (PRADO Jr., 1991).

Na perspectiva de complementar a leitura da formação social brasileira, adiciona-se as contribuições de Fernandes (2000), com ênfase na análise acerca da introdução do capitalismo no país. O autor sustenta que a experiência do Brasil deslocou o sentido revolucionário inspirado no liberalismo, considerando que o mesmo foi assimilado pelas elites nacionais para a manutenção dos privilégios, sem considerar a inclusão das massas no cenário político e decisório. Behring e Boschetti assinalam que tal movimento foi marcado pela ausência de compromisso relativo à defesa dos direitos dos cidadãos por parte das elites econômicas-políticas - “o que é uma marca indelével da nossa formação, fato que é fundamental para pensar a configuração da política social no Brasil” (2006, p. 73).

O marco da Independência, em 1822, estabeleceu o anteparo necessário para a realização da identidade burguesa, contudo, a considerar as ponderações de Fernandes (2000), com ressalvas quanto à sua plenitude, na medida em que preservou a dependência com o capital estrangeiro. Nesse contexto, constituiu-se um ordenamento legal e político voltado para a manutenção dos privilégios da elite e com a economia direcionada para o mercado externo, pautada por uma dinâmica de consumo também externa: "a heteronomia é uma marca estrutural do capitalismo brasileiro e o processo de modernização (conservadora) tenderá a mantê-la" (BEHRING e BOSCHETTI, 2006, p. 76).

Outro ponto de destaque na tese de Florestan Fernandes reporta os entraves que o poder político e social da aristocracia agrária impôs ao processo de modernização, em que pese o arrastado processo de urbanização. Elucida que o processo de transição para o capitalismo no Brasil foi marcado por uma visão 
estreita do dinamismo do mercado interno, destinado, segundo a análise de Behring e Boschetti (2006), a impedir qualquer crescimento a partir de dentro. Em complemento, as autoras destacam que a persistência do trabalho escravo impactou o trabalho livre, minando as possibilidades políticas de um processo radicalizado de transição, possível a partir do impulso crítico do movimento operário - contexto que retardou a entrada da ação operária na cena política, a contar que as primeiras manifestações ocorreram no início do século XX (BEHRING e BOSCHETTI, 2006).

Ao revisitar extratos das reflexões clássicas da formação social brasileira, é possível salientar, reconhecendo os limites que o exercício de síntese possui, traços que ainda hoje repercutem no cenário político cotidiano, ilustrando a análise de Ianni (2004) sobre um Brasil impregnado de vários passados. A consolidação conservadora da dominação burguesa se deu pela via da imposição, movimentos de subjugo da classe operária marcados pela repressão ou pela cooptação. Trata-se de reconhecer, assim, os limites do horizonte histórico da burguesia brasileira, o qual acena para uma perspectiva de autopreservação, de defesa dos próprios interesses. Nas palavras de Fernandes ${ }^{12}$,

(...) isso faz com que a intolerância tenha raiz e sentido políticos; e que a democracia burguesa, nessa situação, seja de fato uma democracia restrita, aberta e funcional só para os que tem acesso à dominação burguesa" (FERNANDES, 1987, p. 212 apud BEHRING e BOSCHETTI, 2006, p. 78).

A trajetória da política social assinala as particularidades da formação escravista e colonial do Brasil, cujo marco de realização histórica diverge da experiência dos países do capitalismo central. A questão social só se coloca como questão política nas primeiras décadas do século $\mathrm{XX}$, a partir do registro das primeiras mobilizações de trabalhadores, responsáveis por inscrever a luta de classes na precursora experiência de direitos no país. Apesar do risco da interpretação pleonástica, ressalta-se o rito das lutas para a afirmação dos direitos, considerando as experiências ditatoriais ${ }^{13}$ que alimentaram o signo da tutela e do

12 FERNANDES, F. A revolução burguesa no Brasil: ensaio de interpretação sociológica. Rio de Janeiro: Guanabara, 1987.

13 1937-1945 - Período referente ao Estado Novo, arregimentado por Getúlio Vargas; e, 1964-1985 - período que compreende o regime ditatorial militar. 
favor como artifícios de dominação, em ciclos de expansão das políticas sociais registrados no Brasil.

Se a política social tem relação com a luta de classes, e considerando que o trabalho no Brasil, apesar de importantes momentos de radicalização, esteve atravessado pelas marcas do escravismo, pela informalidade e pela fragmentação/cooptação, e que as classes dominantes nunca tiveram compromissos democráticos e redistributivos, tem-se um cenário complexo para as lutas em defesa dos direitos de cidadania, que envolvem a constituição da política social. (...) o fundamental, nesse contexto do final do século XIX e início do século XX, é compreender que nosso liberalismo à brasileira não comportava a questão dos direitos sociais, que foram incorporados sob pressão dos trabalhadores e com fortes dificuldades para sua implementação e garantia efetiva. (BEHRING e BOSCHETTI, 2006, p. 81)

Ao se deter à análise das três primeiras décadas do século $\mathrm{XX}$, com o advento da primeira guerra mundial e a crise de 1929, o país assinala uma frente acelerada das relações capitalistas, com significativas repercussões para a cena política, a composição das classes sociais, o Estado e as respostas mobilizadas à questão social. Em linhas gerais, observou-se o incremento das mobilizações dos trabalhadores, além de insatisfações no interior das classes dominantes, dado o declínio das exportações cafeeiras, e, em consequência, a disputa de outras oligarquias agrárias e de setores ligados à recente industrialização.

Na recomposição delineada por Behring e Boschetti (2006), Getúlio Vargas esteve à frente de uma ampla coalização de forças, que impulsionou profundas mudanças no Estado e na sociedade, em consonância com a direção do processo de modernização - denominado movimento de $1930^{14}$. Os anos subsequentes foram marcados pela radicalização dos segmentos ligados aos tenentistas, com destaque para a Intentona Comunista, em 1935, e o crescimento do integralismo, interpretado como o movimento fascista brasileiro. Em 1937, instaura-se a ditadura do Estado Novo, novamente sob a liderança de Getúlio Vargas.

Do período em questão, cabe sublinhar a dinâmica regulatória impulsionada pela administração da Era Vargas, cuja orientação combinou aspectos repressivos e iniciativas políticas, em especial com a inédita regulamentação das

14 As autoras sinalizam que o movimento de 1930 não representou a revolução burguesa no país. No entanto, ponderam que "o incremento da indústria constituiu um momento de inflexão no longo processo de constituição das relações sociais tipicamente capitalistas no Brasil” (BEHRING e BOSCHETTI, 2006, p. 105). 
relações de trabalho no país. A conversão da luta de classes para a colaboração de classes orientou a introdução da política social no Brasil, cuja lógica obedeceu como tendência: direitos certificados pela carteira de trabalho, orientados pela lógica do seguro e da cobertura de riscos, configurando o cariz do cidadão corporativo.

O sistema público de previdência adquire um formato institucional com os Institutos de Aposentadorias e Pensões - IAP, que, segundo Draibe (1990), se expandem na década de 1930, com provisões ligadas à perda ou redução da capacidade laborativa, direcionados para categorias de trabalhadores estratégicas, sob orientação da lógica contributiva do seguro social. A autora destaca, ainda, a formulação do Ministério da Educação e Saúde Pública no período, inaugurando a intervenção do Estado na área da saúde, a partir de dois eixos: a saúde pública e a medicina previdenciária, vinculadas aos IAP, destinado às categorias que dispunham de suas coberturas.

Neste ponto da análise, a discussão se detém à trajetória da Assistência Social, com o intuito de elucidar, a partir de uma síntese das principais experiências e formatos institucionais, os traços constitutivos de sua gênese e desenvolvimento no âmbito das políticas sociais brasileiras. A sistematização de Draibe (1990) sustenta que é difícil estabelecer com precisão o lugar de referência da assistência social no Brasil, em razão do caráter fragmentado, diversificado, desorganizado, indefinido e instável das suas configurações.

De todo modo, a criação da Legião Brasileira de Assistência (LBA), em 1942, representou um marco para a política, dado o movimento de centralização, na esfera federal, das iniciativas voltadas para o atendimento das famílias dos militares envolvidos na Segunda Guerra Mundial. Sob a coordenação da primeiradama, Darci Vargas, a LBA inicia um movimento de ações tutelares, favores e clientelismo, mediado pelo Estado - tendências que atravessam a constituição da assistência enquanto política social. Posteriormente, a LBA assume a atribuição de integrar a assistência social no Brasil, agregando instituições privadas conveniadas, sem superar, entretanto, a feição assistencialista, seletiva e de instrumento político das primeiras-damas.

Segundo a análise de Iamamoto e Carvalho (2003), inicialmente estruturada para prestar assistência às famílias dos convocados, a LBA passou a 
atuar em praticamente todas as áreas de assistência social, definidas como: assistência à maternidade, infância e à velhice; aos doentes, aos necessitados, aos desvalidos; melhoria da alimentação e habitação dos grupos menos favorecidos; difusão da educação popular, levantamento do nível de vida dos trabalhadores e organização racional de seus lazeres. Os autores apontam que a LBA deflagou uma estrutura fundamental para a reorganização e incremento do aparelho assistencial privado, com acentuado esforço para aprimorar a linha assistencial para a maternidade e infância.

Os autores recuperam, ainda, a estrutura da Fundação Leão XIII, institucionalizada em 1946, por meio de um decreto presidencial, que a oficializa como primeira grande instituição assistencial voltada para a atuação com os habitantes das grandes favelas. A intervenção circunscrita às regiões faveladas justificava-se pela concentração da população pobre que, à época, ocupavam extensões significativas dos centros urbano industriais. A atuação da Leão XIII foi dedicada às favelas da cidade do Rio de Janeiro ${ }^{15}$, com o intuito de “(...) trabalhar pela recuperação das populações das favelas, tendo em vista a extrema precariedade material e moral que estas atravessavam" (IAMAMOTO e CARVALHO, 2003, p. 283).

Os investimentos voltados para a dita recuperação das populações faveladas decorrem da identificação de um pretenso risco atribuído às favelas, dado o avanço da influência do Partido Comunista do Brasil (PCB) nas regiões dos morros cariocas. A estrutura da Leão XIII é mobilizada para dar conta de uma ação político-assistencial imediata junto aos segmentos populares, com o intuito de se contrapor à organização autônoma dos movimentos, ainda que no plano do discurso oficial o slogan se detivesse ao compromisso de "barrar o avanço do comunismo" (IAMAMOTO e CARVALHO, 2003, p. 284). Para tanto, a Fundação Leão XIII representou a organização, sob responsabilidade do Estado, do aparato assistencial para consolidar o controle da população pobre.

A estratégia de ramificação nas favelas partiu da implementação dos Centros de Ação Social (CAS) nas principais áreas da cidade. O programa dos CAS era baseado numa plataforma de ação centrada na Educação, tomada como principal 
artifício para atingir e redimir as famílias pobres. Em suma, para Iamamoto e Carvalho, “(...) o projeto de educação popular da Leão XIII assumiu o sentido de levantamento moral das populações faveladas. Projeto ao qual não é estranha a perspectiva do controle das massas" (2003, p. 289).

O histórico da Fundação Leão XIII, detido à atuação junto à população favelada no Rio de Janeiro, permitiu desvelar características de uma estrutura assistencial designada ao controle e cerceamento, no âmbito do aparato supostamente protetivo do Estado. A instituição chancelou práticas voltadas para conter uma massa genérica de marginalizados, cujo crescimento contínuo e reprodução de comportamentos desviantes, ascenderam como um desafio - nas palavras de Iamamoto e Carvalho, “(...) elementos de anomia no interior da ordem burguesa" (2003, p. 290). A premissa da Leão XIII alinhou, como prerrogativa da intervenção dos CAS, o controle das condutas dos indisciplinados com o alívio dos aspectos mais gritantes da miséria social.

Coloca-se aí, um problema central que deverá ser enfrentado pelo Serviço Social da Fundação Leão XIII: ocupar-se dessa população marginalizada, que por suas ligações extremamente irregulares com o mercado de trabalho - isto é, por não estarem sob o controle contínuo e prolongado da agência básica de socialização, a empresa, e por suas condições de existência, são verdadeiros delinquentes sem delito. A resposta, em face da situação de miséria material e moral dessas populações, será, mais uma vez, a pesquisa e classificação dos desvios e as ações paliativas, que tem em vista estender a área de influência e controle da instituição. Ante a incapacidade de agir com vistas a modificar as terríveis condições de existência daquelas populações, o projeto de prática da instituição se proporá a regenerá-la, isto é, contrapor-se às diferentes manifestações de inadaptação e rejeição às normas vigentes. (IAMAMOTO e CARVALHO, 2003, p. 290)

A despeito do distanciamento histórico do registro exposto, a aproximação com a temática em estudo, qual seja, as estratégias de controle contemporâneas reproduzidas pela Política de Assistência Social, é incisiva, considerando a lógica de enquadramento punitivo direcionada às populações pobres. O histórico da LBA, marcado pelo viés seletivo e de tutela, associado ao disciplinamento perpetrado pelos CAS da Fundação Leão XIII, remontam elementos passíveis de identificação com as normativas da PNAS/2004. O estudo, no decorrer das discussões teóricas, bem como na análise dos documentos em vigor, estabelece as mediações necessárias para reconhecer os pretéritos da Assistência Social que insistem em 
permanecer e a moldar a experiência do presente - tal como nos ensina, Caio Prado Júnior (1991; 2000), Florestan Fernandes (2000) e Octavio Ianni (2004).

O exercício de revisitar a história permite reconhecer as incômodas conexões que a Assistência Social tem com as precursoras ações sociais pavimentadas pelo Estado brasileiro. Trata-se de um quadro de interpretação que desdobra, assim como apontado nas protoformas assistenciais na Europa, o binômio da proteção e punição, delineado por contornos próprios da formação social do país. A partir da identificação das aproximações e permanências do passado nas estruturas do presente, torna-se possível distinguir a centralidade das expressões da questão social ontem e hoje, atualizadas a depender das conjunturas históricas, porém, decisivas para traduzir as contradições do capitalismo e as respostas forjadas, no campo assistencial, para o enfrentamento de suas sequelas.

$\mathrm{Na}$ área da infância e juventude, os registros históricos reforçam o caráter punitivo das legislações e instituições designadas para a contenção da chamada delinquência juvenil. Em 1927, foi aprovado o Código de Menores, de natureza terminantemente repressiva. No ano de 1941 é aprovado o Serviço de Assistência ao Menor (SAM), cujo teor reporta objetivos declarados de proteção ao segmento, porém, em função da ausência de financiamento e por influência da cultura da época ${ }^{16}$, prevaleceu a coerção e os maus-tratos aos jovens pobres e aqueles tomados como delinquentes (IAMAMOTO e CARVALHO, 2003).

O reconhecimento da criança e do adolescente como sujeito de direitos, ancorados na doutrina do melhor interesse do segmento, são conquistas expressivas do campo da cidadania infanto-juvenil. A promulgação do Estatuto da Criança e do Adolescente (ECA) é, decerto, uma das maiores conquistas registradas na trajetória das políticas de proteção social brasileiras. Os direitos ligados ao segmento são transversais, garantias que exigem respostas concertadas das políticas sociais.

O estatuto teórico e normativo da criança e do adolescente serão retomados adiante, considerando a atenção especializada e as perspectivas de seguranças afiançadas pela Política de Assistência Social contemporânea. Por ora, cabe problematizar a materialidade das garantias para a infância e adolescência,

16 E que ainda se faz presente, a considerar os indicadores de violência e letalidade que abrangem a juventude e, em particular, a juventude negra no Brasil. Os dados em questão serão analisados no Capítulo III. 
considerando a leitura que vincula, no passado e se reconfigura no presente, a noção de perigo às crianças e adolescentes pobres. $\mathrm{O}$ sentido da proteção se volta para a sociedade ou para o segmento em situação de risco?

O período histórico subsequente envolve o regime ditatorial à redemocratização, contexto que registra, na dinâmica internacional, a reação burguesa à crise do capital - conforme explicitado ao término do tópico anterior. Behring e Boschetti (2006) sinalizam que o primeiro elemento a ser considerado é uma aparente falta de sincronia entre os processos brasileiros e os acirramentos internacionais. Em continuidade, alertam que o aparente descompasso se relaciona ao salto econômico promovido pela ditadura, ancorado no projeto de internacionalização da economia brasileira. Nesse cenário,

(...) a ditadura militar reeditou a modernização conservadora como via de aprofundamento das relações sociais capitalistas no Brasil (...), reconfigurandose nesse processo a questão social, que passa a ser enfrentada num mix de repressão e assistência, tendo em vista manter sob controle as forças de trabalho que despontavam. Nesse quadro, houve um forte incremento da política social brasileira. (BEHRING e BOSCHETTI, 2006, p. 136)

Em linhas gerais, a política social do período ditatorial reuniu estratégias de expansão e modernização em prol da adesão e legitimidade ao bloco militartecnocrático-empresarial, num contexto de sensíveis danos para as liberdades democráticas e imposição do controle por meio da censura, tortura e prisão das vozes dissonantes (FALEIROS, 2000). Destaca-se, nesse contexto, a institucionalização, em 1974, do Ministério da Previdência e Assistência Social, que incorporou a LBA, a Fundação Nacional para o Bem-estar do Menor $(\text { FUNABEM })^{17}$, a Central de Medicamentos (CEME) e a Empresa de Processamento de Dados e Previdência Social (DATAPREV).

Adiante, mais precisamente no ano de 1977, esse complexo foi reformulado, convertendo-se no Sistema Nacional de Assistência e Previdência Social (SINPAS), que passou a compreender o Instituto Nacional de Previdência Social (INPS), o Instituto Nacional de Assistência Médica (INAMPS) e o Instituto

17 Criada em 1965, a Funabem substituiu o SAM, extinto em 1964, sem alterar, entretanto, seu caráter punitivo. Traço que se manteve, inclusive, no Código de Menores de 1979 (BEHRING e BOSCHETTI, 2006). 
Nacional de Administração da Previdência Social (IAPAS), além das instituições mencionadas acima.

A tendência de ampliação foi notória na Previdência Social, que passou a contemplar os trabalhadores rurais no Fundo de Assistência ao Trabalhador Rural (Funrural) (1971), as empregadas domésticas (1972), os jogadores de futebol e os autônomos (1973), e ainda os ambulantes (1978). Em 1974, foi instituída a Renda Mensal Vitalícia (RMV) para os idosos pobres, assegurada para aqueles com registro de contribuição previdenciária por um ano, no mínimo. (BEHRING e BOSCHETTI, 2006)

Na área da Saúde, destaca-se a ênfase no atendimento curativo, individual e especializado, com forte apelo à medicalização. Autores dedicados ao estudo das políticas de saúde pública no país identificam a estreita relação da administração militar com segmentos da indústria farmacêutica e de equipamentos médicohospitalares, orientados pelo crivo da lucratividade (BRAVO, 1996). No campo da assistência social, a política, com o menor registro de investimento, importa ressalvar, permaneceu restrita à rede conveniada e dos serviços prestados pela $\mathrm{LBA}^{18}$.

A partir do panorama dedicado às políticas setoriais, o qual atestou o impulso da administração ditatorial às políticas públicas, ainda que restritas quanto às condições de acesso, o regime militar permitiu a abertura da saúde, previdência e educação para a exploração de setores da iniciativa privada, dando forma ao sistema dual das políticas sociais - demarcadas pelo critério de quem pode ou não arcar com os custos de acesso. Como destacado no tópico anterior, identifica-se aqui as ações precursoras de mercantilização das políticas que, na atualidade, respondem pela pilhagem dos bens públicos, em especial nas áreas da Previdência, Saúde e Educação, em contraponto com a ampliação dos programas assistenciais.

Tem-se aqui uma das principais marcas do regime militar para a política social, que nos aproxima, na avaliação de Behring e Boschetti (2006), do sistema

18 Destaca-se, ainda, o investimento na política de habitação, com a criação do Banco Nacional de Habitação (BNH). De acordo com Behring e Boschetti (2006), tratava-se de uma estratégia para impulsionar a economia por meio do incremento da construção civil na construção de moradias populares, bem como com a implantação de fundos de indenização de trabalhadores. Iniciativas que instituíram mecanismos de poupança compulsória para o financiamento da política habitacional, como o Fundo de Garantia do Tempo de Serviço (FGTS), Programa de Integração Social (PIS) e Programa de Formação do Patrimônio do Servidor Público (PASEP). 
norte-americano de proteção social ${ }^{19}$, considerando o afastamento da noção universalista da experiência do Welfare State europeu. Outro traço constitutivo do período é sublinhado por Faleiros (2000), ao confrontar que, mesmo com uma ampliação dos serviços públicos e privados, uma expressiva parcela de brasileiros permaneceu excluída do denominado complexo assistencial-industrialtecnocrático-militar.

Em que pese o fluxo de ampliação, com todas as ressalvas apontadas, das políticas sociais, a década de 1970 antecipou os sinais de esgotamento do projeto modernizador e conservador da ditadura militar, considerando a regressão da economia mundial e os rebatimentos para a dinâmica do mercado interno. A década de 1980, em consequência, será marcada pela distensão e pela abertura lenta e gradual do regime, dando forma a um processo de transição condicionado pela adesão às orientações neoliberais - já em curso, à época, em escala global.

Reconhecida como a década perdida, os anos 1980 foram marcados pela agudização da questão social, em que pese as fraturas decorrentes de um projeto de desenvolvimento destacado para frações da classe média e da burguesia nacional, cujo saldo creditado ao dito milagre brasileiro jamais fora redistribuído. O período demarca, ainda, as conquistas democráticas, a mobilização por pautas progressistas, em franca disputa no processo constituinte que antecedeu a CF de 1988.

No plano econômico, ressalta-se a crise do endividamento, responsável pelos indicadores de empobrecimento generalizado na América Latina, características históricas que, na leitura de Behring e Boschetti (2006), foram exacerbadas no contexto dos anos 1980. Quando a estagnação chega à periferia, declinando os indicadores de crescimento e, em consequência, a própria estrutura autoritária dos governos militares, os canais democráticos são ampliados.

Com efeito, a entrada dos anos 1990, no Brasil, é marcada pela consolidação democrática na esfera política e, do ponto de vista econômico, pela imposição de um discurso da necessidade de ajustes e dos planos de estabilização - cenário de avanço das contrarreformas.

19 Em complemento, destaca-se a caracterização de Vianna a respeito da "americanização perversa", segundo a qual o sistema de proteção social brasileiro avançou no fortalecimento da lógica do contrato, considerando que o sistema público se “(...) especializou no (mau) atendimento dos muito pobres", ao mesmo tempo em que “(...) o mercado de serviços médicos, assim como o de previdência, conquista adeptos entre a classe média e o operariado" (VIANNA, 1998, p. 142). 
Apesar do ascenso das lutas democráticas e dos movimentos sociais, que apontavam condições políticas e uma base de legitimidade forte para a realização de reformas efetivas, muitas contra tendências se interpuseram a essa possibilidade. Os anos 1990 até os dias de hoje têm sido de contrarreforma do Estado e de obstaculização e/ou redirecionamento das conquistas de 1988, num contexto em que foram derruídas até mesmo aquelas condições políticas por meio da expansão do desemprego e da violência. (BEHRING e BOSCHETTI, 2006, p. 147)

Ao retomar o debate da Assistência Social, a CF de 1988 a instituiu como uma política social não contributiva, cujos objetivos preveem a proteção à família, à maternidade, à infância, à adolescência e à velhice, além das garantias voltadas para a integração de pessoas com deficiência e a garantia de um salário mínimo mensal para este segmento, bem como à pessoa idosa, quem não possuam recursos necessários à própria manutenção ou de tê-la provida pelos respectivos núcleos familiares.

O desenho constitucional da Assistência Social incluiu os mesmos grupos privilegiados na organização precursora da política, considerando o privilégio da atenção detida à maternidade e infância, assim como a velhice e pessoas com deficiência. Sublinha-se, ainda, o lugar de destaque às necessidades materiais e sociais que, no impedimento da satisfação por parte das famílias, legitimam a vinculação aos programas assegurados pela política.

A centralidade da família, disposto no princípio da matricialidade sociofamiliar na PNAS/2004, e as premissas de proteção aos segmentos vulneráveis, que sustentam as seguranças socioassistenciais do SUAS, convertem e atualizam prerrogativas históricas da Assistência Social. A identificação da permanência, a priori, não se coloca como um traço contraproducente, ao contrário, observa a maturidade da legislação brasileira em acompanhar os avanços das pactuações internacionais em matéria de Direitos Humanos. A crítica se apresenta à ambiguidade da responsabilização e titularidade dos direitos, na medida que a política, inscrita no campo dos direitos, preserva a família como instância primária de cuidados - e, na lógica atual, passível de sanções punitivas aplicadas tanto na esfera assistencial e judicial.

Em um breve retrospecto, da Carta Constitucional de 1988 à Lei Orgânica de Assistência Social (LOAS), foram necessários cinco anos para a regulamentação da Assistência Social, formalizada, apenas, em 1993. A título de exemplo, a 
regulamentação da Saúde ocorreu em 1990, mesmo ano da promulgação do ECA. O lapso para a formalização possui estreita relação com o panorama debatido, haja vista as reconfigurações previstas para o ajuste estrutural da economia e a retração dos investimentos nas políticas sociais.

É possível afirmar, que a década de 1990 é marcada pelo distanciamento entre o sistema de garantias e proteção anunciado no marco jurídico formal e a efetivação de tais prerrogativas, atrelado ao discurso de incentivo às práticas filantrópicas e apelo à solidariedade e ampliação do terceiro setor (MONTANO, 2007). Os organismos multilaterais, como o Banco Mundial (BM) e o Fundo Monetário Internacional (FMI), responsáveis por estabelecer as prerrogativas de ajuste para os países periféricos, determinaram, como medidas de enfrentamento da crise, a limitação da intervenção do Estado e, em última instância, adequação às proposições da contrarreforma neoliberal (BEHRING, 2002).

A pauta de adequações repercutiu, decisivamente, na adoção do discurso de enfrentamento à pobreza, como uma diretriz alinhada ao crescimento econômico nos países periféricos. A intervenção se volta, portanto, para o desenvolvimento das capacidades dos indivíduos e das famílias, como fundamento das potencialidades necessárias para a superação da pobreza.

O que a perspectiva da capacidade faz na análise da pobreza é melhorar o entendimento da natureza e das causas da pobreza e privação desviando a atenção principal dos meios - e de um meio específico que geralmente recebe atenção exclusiva, ou seja, a renda - para os fins que as pessoas têm razão para buscar e, correspondentemente, para as liberdades de poder alcançar esses fins (...). Daí a relevância da perspectiva da pobreza baseada na capacidade. (SEN, 2017, p.123)

Em concordância com Couto et al (2017), afirma-se que a implantação da PNAS/2004 e do SUAS, num contexto histórico regressivo, de aprofundamento de expressões da "questão social", é marcada por processos de resistências, no encaminhamento de uma agenda pública de efetivação dos direitos socioassistenciais. Na esteira do reconhecimento da PNAS/2004 e, a posteriori, do SUAS, decorre a articulação em todo o território nacional das responsabilidades, serviços, benefícios e ações da assistência social, apoiado num modelo de gestão compartilhado, pautado no pacto federativo, onde são definidas as atribuições dos três níveis do executivo na provisão dos direitos socioassistenciais. 
Em contraponto, tais parâmetros assimilaram categorias conservadoras, que embasam um desenho normativo e operacional alijado das determinações concretas da ordem socioeconômica brasileira - no qual o desenvolvimento de capacidades, como defendido por Sen (2017), ascende como resposta aos processos de exclusão social e riscos vivenciados pelas famílias em situação de vulnerabilidade social (BRASIL, 2004). Categorias que omitem a razão contraditória das políticas sociais no capitalismo e reforça a centralidade da Assistência Social como mecanismo de enfrentamento das desigualdades sociais compreensão que a situa para além de uma política de proteção social.

O percurso analisado apresentou traços constitutivos da política social no Brasil, privilegiando a construção de um referencial histórico da política de Assistência Social. O desafio de sistematizar aspectos cruciais, decerto, abreviou passagens relevantes da política em cena. Contudo, ao assinalar tendências que atravessam suas diferentes versões institucionais, é possível reconhecer a convergência das respostas protetivas e dos rebatimentos punitivos como elementos que dão forma à trama assistencial no país.

A análise retrospectiva da política foi pautada na premissa de que cada experiência e formato da Assistência Social fundamentam representações das articulações e projeções próprias do tempo histórico vivido. A linha interpretativa se aplica, igualmente, às características que se reatualizam, ao evolver das distintas conjunturas sociopolíticas. Os apontamentos são necessários para contextualizar a leitura dos documentos normativos vigentes, os quais introduzem referenciais inéditos para a Assistência Social brasileira. Ou seja, se estabelece o desafio de reconhecer, no ordenamento atual, as particularidades contemporâneas que dão sentido e forma ao binômio proteção e punição, a partir das categorias e justificativas que norteiam os documentos da PNAS/2004 e da PSE de média complexidade, em particular. 


\section{3.}

\section{Tendências da Política de Assistência Social na Contemporaneidade}

Conforme explicitado nas linhas introdutórias da dissertação, a PNAS/2004 apresenta a Assistência Social como política de Proteção Social, com a prerrogativa de garantir as seguintes seguranças: segurança de rendimento e autonomia, de acolhida e de convívio familiar. O documento define famílias e indivíduos, em situação de vulnerabilidade e riscos, como o público usuário da Política. No âmbito da gestão, a PNAS/2004 se estrutura na perspectiva do SUAS, o qual parametriza a regulação e organização nacional das ações socioassistenciais. Os serviços, programas, projetos e benefícios tem como foco prioritário a atenção às famílias e indivíduos, além do território como base de organização.

No que se refere à PSE, a PNAS/2004 determina o atendimento às famílias e indivíduos em situação de risco pessoal e social, com o propósito de garantir o acesso a serviços de apoio e sobrevivência, como a inclusão em redes sociais de atendimento e solidariedade (BRASIL, 2004). Na ótica da Política, as ações socioassistenciais da PSE devem desencadear estratégias de atenção sociofamiliar que contribuam para a elaboração de novas referências morais e afetivas, sendo direcionadas para grupos tidos como vulneráveis, como crianças, adolescentes, jovens, idosos, pessoas em situação de rua com direitos ameaçados ou violados (BRASIL, 2004).

Como pontuado na seção de abertura da dissertação, é possível distinguir um vocabulário socioassistencial particular a partir da PNAS/2004, disposto por referenciais e categorias inéditas, quando comparado aos ciclos normativos anteriores. A estrutura vigente da Política de Assistência Social introduz menções às categorias vulnerabilidade, território, risco social e pessoal, matricialidade familiar, vínculo familiar e comunitário, violência intrafamiliar, violação de direitos, vigilância socioassistencial, dentre outros - termos que passam a pautar a disposição dos serviços, e, assim, definir e orientar o planejamento das ofertas e garantias socioassistenciais.

Como pontuado por Behring (2016), a política de Assistência Social atualizou o vocabulário das políticas sociais contemporâneas, ao tomar como pressuposto o risco e as situações de vulnerabilidade. E a virada conceitual 
acompanha, concomitantemente, a omissão da essência contraditória das políticas sociais no capitalismo - definida, de forma concisa, pela aludida autora:

Em síntese, a política social e os direitos que ela materializa são mediações importantes na totalidade concreta - a sociedade burguesa - desde quando os trabalhadores emergem na cena pública, pautando suas condições de vida e trabalho como "questão social" (...). São produto histórico-social da luta de classes, e como tal se reconfiguram, acompanhando os movimentos do trabalho e do capital e seus impactos sobre o Estado, como um componente central na garantia das condições gerais de produção e reprodução social (BEHRING, 2016, p.93)

Ao explorar o vocabulário socioassistencial e, assim, as categorias que avançam como referenciais na PNAS/2004, é possível identificar a incorporação de conceitos que sugestionam, na esteira das omissões assinaladas por Behring (2016), critérios seletivos e indutores de uma responsabilização subjetiva, que partilham, no neoliberalismo, um estratégico papel - haja vista a individualização indiscriminada, com ramificações em todos processos da vida social.

Nesse contexto, o debate exercita o diálogo com Dardot e Laval (2016), ao tomar como pressuposto de análise a tese da racionalidade neoliberal - leitura que ultrapassa a compreensão do neoliberalismo como ideologia ou política de orientação econômica. Para os autores, trata-se de um sistema normativo que ampliou sua influência ao mundo, estendendo a lógica do capital a todas as relações sociais e a todas as esferas da vida (DARDOT e LAVAL, 2016).

A arguição dos autores posiciona a interpretação do neoliberalismo ao patamar de uma racionalidade, dotada de uma capacidade de produzir e determinar relações sociais e subjetividades, moldadas com base nos princípios de um universo em competição generalizada. A interpretação amplia, portanto, o espectro das avaliações centradas nos efeitos das desregulamentações das políticas neoliberais, na medida em que as sequelas se estendem para além do enfraquecimento das instituições e derruição de direitos - com o neoliberalismo o que se coloca em disputa é a própria condição da existência (DARDOT e LAVAL, 2016).

A tese defendida por Dardot e Laval (2016) sustenta que a racionalidade neoliberal tem como característica principal a generalização da concorrência como norma de conduta e da empresa como modelo de subjetivação (DARDOT e LAVAL, 2016). Nesse sentido, o neoliberalismo é a razão do capitalismo contemporâneo, da experiência de um modo de produção plenamente assumido 
como construção histórica e norma geral da vida. O neoliberalismo, na acepção dos autores, pode ser definido como um conjunto de discursos, práticas e dispositivos que determinam um novo modo de governo dos homens, regido pelo princípio universal da concorrência.

Dardot e Laval (2016) analisam o neoliberalismo pela via de uma reflexão política sobre o modo de governo, de inspiração foucaultiana ${ }^{20}$. A partir dessa linha de análise, os autores refutam perspectivas que definem o neoliberalismo em termos de retirada do Estado diante do mercado. Advertem que, na contracorrente da percepção imediata de que os mercados dominaram os Estados e ditam a política que estes devem seguir, os Estados introduziram e universalizaram na economia, na sociedade e até neles próprios a lógica da concorrência e o modelo de empresa. Nesse ponto, Dardot e Laval (2016) citam as análises de Marx e Polanyi, segundo os quais o mercado não atua sozinho, considerando a tendência histórica de amparo exercida pelo Estado.

Ao investirem na interpretação do neoliberalismo pela via da razão governamental, os autores remontam o plano de análise de Foucault, para o qual o governo liberal, fundamentado num conjunto de dispositivos de controle da população e de orientação de condutas (a biopolítica), encontra no neoliberalismo uma sistematização inédita (idem, 2016). Para tanto, exploram a própria noção de governo, ao sustentarem não se tratar da instituição governo, mas, antes, da atividade que consiste em reger a conduta dos homens com instrumentos de Estado. Em outros termos, acenam, na esteira do pensamento foucaultiano, para a compreensão de governo como atividade e não como instituição (idem, 2016).

A referência da análise do neoliberalismo a partir do modo de governo, explicitado por Dardot e Laval em estreita convergência com a obra de Foucault, descortina arranjos de controle e enquadramento presentes na estrutura normativa da Assistência Social na contemporaneidade. Ao dotar como princípios de um dado modo de governo a concorrência e a competição empresarial, enquanto elementos que extrapolam a esfera econômica, a racionalidade política do neoliberalismo

$20 \mathrm{O}$ plano de análise escolhido para o estudo do neoliberalismo remonta à tese de Foucault, para o qual trata-se de um plano de análise possível - o da razão governamental, isto é, dos tipos de racionalidade que são empregados nos procedimentos pelos quais se dirige, através de uma administração de Estado, a conduta dos homens. Uma racionalidade política é, nesse sentido, uma racionalidade governamental. Os autores registram que a explanação do curso "Nascimento da Biopolítica" constitui a referência central pela qual se ordena toda a análise do neoliberalismo. 
mobiliza distintos procedimentos de poder para direcionar condutas, sendo a Assistência Social um recurso privilegiado para a estratégia de conversão dos direitos em aquisições privadas, pela via das propostas de intervenção corretiva e de responsabilização pelos processos de cuidado familiar.

Os arranjos institucionais da PSE de média complexidade admitem recursos de disciplinamento que, mediados pelas instituições do Sistema de Justiça, vislumbram a conversão de condutas, quando da identificação de contextos que fragilizam as noções de cuidado e proteção delegadas às famílias. Ou seja, os ritos que orientam as condutas, tanto nos trâmites seletivos da assistência social, como na esfera legal do direito, determinam a assimilação tácita da responsabilização do indivíduo, instado por fazer valer a subjetividade empresarial, necessária para subverter a proteção social de domínio estatal para a dimensão privada.

Nesse ponto, é possível constatar um redirecionamento do princípio regulador do Estado Social no século XX. Como observado, as garantias socialmente legitimadas decorriam dos imperativos da relação salarial, contexto em que o Estado assegurava as garantias necessárias para a reprodução da força de trabalho e atendimento de demandas da classe trabalhadora. No cenário atual, a experiência do trabalho, estabelecida pela via do contrato formal, atravessa um período de transição, em que pese a expansão, sinalizada por Dardot e Laval, da racionalidade do mercado a toda forma de existência - condição que enquadra a subjetividade humana à "forma-empresa” (idem, 2016).

Se a trajetória da proteção social na sociedade capitalista é determinada pela referência do trabalho, decerto o cenário contemporâneo fragiliza a concepção que a vincula como marco da regulação dos conflitos entre o capital e o trabalho. O recuo das garantias advindas dos arranjos formais do trabalho, além do avanço privatista em políticas de alcance universal, como a Saúde e Educação, assumem contornos dramáticos e, considerando as perversas e excludentes estruturas da sociedade brasileira, manifestam cenários trágicos, pautados pelo signo da desigualdade e barbárie.

Observa-se, portanto, a conversão da assistência social como premissa de ativação para o trabalho, independente da forma que este se apresente, considerando as experiências dos serviços voltados para o despertar das vocações 
empreendedoras e autônomas ${ }^{21}$. A assistência, portanto, integra o conjunto de ações necessárias para a incorporação do ideal do trabalho numa perspectiva individual, a dimensão produtiva concebida e materializada pelo próprio sujeito, capaz de suprir todas as instâncias da clássica (e fragilizada) relação salarial.

No contexto da PSE de média complexidade, por sua vez, a relação do cuidado individualizado é ressaltada, considerando a intervenção estatal legitimada pela tônica da violação de direitos, em especial das ocorrências relacionadas à própria dinâmica familiar. Como assinalado, a família pobre é compelida a incorporar um padrão de satisfação das necessidades, sob pena das sanções previstas pelos programas de transferência de renda ${ }^{22}$ e/ou submissão a acompanhamentos socioassistenciais supervisionados por órgãos ligados ao sistema de justiça. A reparação de direitos decorre, nessa lógica, tanto pelo Estado, ainda reconhecido como ator estratégico para a reprodução, como pela expectativa de restituição advinda do núcleo familiar - seja pela correção de condutas ou pela aquisição, por recursos privados, das demandas apresentadas pelos membros sob sua responsabilidade.

Os desígnios da assistência social no cenário atual admitem, sem a pretensão de esgotar as distintas nuances de análises, perspectivas que reatualizam a clássica relação de atração e rejeição entre o trabalho e a assistência social (BOSCHETTI, 2016; 2018). Diante do exposto, é possível reconhecer aspectos da Política que se voltam para a admissão de uma lógica de trabalho autônoma, desprovida, em sua maioria, de garantias e direitos advindos da relação salarial.

21 Destaque para o ACESSUAS TRABALHO, iniciativa na qual "a Assistência Social reconhece sua responsabilidade na mobilização, encaminhamento e acompanhamento dos usuários em situação de vulnerabilidade ou risco social, para acesso aos cursos de qualificação profissional e demais ações de inclusão produtiva, visando a inserção dessa parcela da população ao mundo do trabalho (BRASIL, 2012d, p. 13).

22 As condicionalidades do Programa Bolsa Família (PBF) envolvem o monitoramento dos seguintes grupos: crianças e dos adolescentes de 6 a 17 anos deverão ter a frequência escolar verificada; crianças de 0 a 6 anos que deverão ter o calendário vacinal, o peso e a altura acompanhados; além das mulheres em idade fértil para identificação das gestantes e acompanhamento do pré-natal. Em relação às sanções, o Programa prevê repercussões por etapas, a conferir: advertência: a família é comunicada de que algum integrante deixou de cumprir condicionalidades, mas não deixa de receber o benefício; bloqueio: o benefício fica bloqueado por um mês, mas pode ser sacado no mês seguinte junto com a nova parcela; suspensão: o benefício fica suspenso por dois meses, e a família não poderá receber os valores referentes a esse período; cancelamento: a família deixa de participar do PBF. Acesso em 11/04/2020, disponível em: http://www.desenvolvimentosocial.gov.br/Portal /servicos/bolsa-familia/gestao-do-programa1/condicionalidades 
Assim como, destaca-se o direcionamento da Assistência que se coloca como aporte para a intromissão do cuidado individualizado, passível de realização pela via do acesso mercantilizado, em que pese os expressivos recuos das demais políticas sociais.

A Política de Assistência Social, nesse contexto, assume a dita projeção de totalidade da proteção social, às custas de estratégias de focalização e transferência de renda, com o intuito de situar parcelas da população, alijadas do processo de compra e venda formal da força de trabalho, na órbita do consumo de mercadorias. Ou seja, trata-se de compor as necessidades daqueles que se encontram à margem da aquisição de elementos da vida social que, na atualidade, assumem a forma de mercadorias, cujo acesso se dá, tão somente, pela mediação do mercado. A ilustração remonta às considerações de Virgínia Fontes (2011), para a qual as expropriações contemporâneas ${ }^{23}$ tornaram-se agressivas e potencialmente ilimitadas, onde a "racionalidade humana é reduzida a cálculo, a uma relação custobenefício. Tudo deve ser expropriado, fragmentado, e tornar-se comensurável (terra, ar, água, direitos, afetos, amores) (...)”(FONTES, 2017, p. 413).

Nesse aspecto, cabe a ampliação da análise centrada nas políticas neoliberais, então voltadas, ainda que não somente, para a programática destrutiva no âmbito das regulamentações e direitos. Para tanto, retoma-se o diálogo com Dardot e Laval, segundo os quais o neoliberalismo “(...) produz certos tipos de relações sociais, certas maneiras de viver, certas subjetividades” (2016, p.16). Como sinalizado, o que se coloca como central é o padrão de relações forjadas num universo de competição generalizada, que justifica relações sociais segundo a ótica do mercado, onde o indivíduo é impelido a conceber a si mesmo e a comportar-se como uma empresa - ou seja, subjetividades remodeladas segundo o modelo do mercado.

$23 \mathrm{O}$ tema das expropriações contemporâneas é atravessado por polêmicas nas Ciências Sociais e Humanas, de modo que inúmeras produções recentes do Serviço Social problematizam as divergências das interpretações em disputa. Não obstante o dissenso teórico, a análise dialogou com as proposições de Fontes $(2011 ; 2017)$, que, ancorada na perspectiva marxiana, avalia que a expropriação no capitalismo não pode ser reduzida a um processo meramente econômico, considerando se tratar de um fenômeno de ordem social. "A expropriação não pode ser considerada como um fenômeno apenas econômico, uma vez que é propriamente social, mesmo se parcial ou limitada. Trata-se da imposição - mais ou menos violenta - de uma lógica da vida social pautada pela supressão de meios de existência ao lado da mercantilização crescente dos elementos necessários à vida, dentre os quais figura centralmente a nova necessidade, sentida objetiva e subjetivamente, de venda da força de trabalho". (FONTES, 2011, p.88) 
Com efeito, é possível inferir que a Política de Assistência Social, no lastro das duas últimas décadas, incorporou elementos necessários para a subjetivação do mercado como um padrão para a regulação das relações sociais, considerando, especialmente, a amplitude dos programas de transferência de renda e suas respectivas exigências, bem como a adoção de pautas que privilegiam a intervenção direcionada às famílias em situação de pobreza e territórios, tomados como atores estratégicos de proteção social.

No entanto, tal cenário suscita indagações quanto ao sentido e direcionamento dos parâmetros que dão forma à Política na atualidade - se a responsabilização das famílias e os atributos morais atrelados à assistência social não se apresentam como fenômenos inéditos, ao contrário, são reatualizados em distintas conjunturas históricas, como que o avanço da lógica privatista e mercantilizada das políticas sociais potencializa suas contradições e limites para a realização dos direitos numa perspectiva emancipatória?

A discussão encaminha, assim, um necessário debate acerca das categorias que orientam e distinguem os níveis de complexidade das ações socioassistenciais a partir da PNAS/2004. A família vulnerável e/ou exposta a situações de riscos assume a titularidade das garantias previstas nas proteções afiançadas pelo SUAS, como alvo de intervenções que redirecionam o acesso ao mercado e preservam/restituem vínculos familiares e comunitários. E, no que se refere à PSE de média complexidade, a Política reafirma a responsabilização da família como instância primordial de cuidados e segurança e, assim, admite como campo de intervenção dos serviços socioassistenciais distintas manifestações do fenômeno da violência.

Decerto, a proposição de um vocabulário específico se colocou como um atributo de valorização de uma política historicamente subjugada no campo da proteção social brasileira. Dotado de referenciais políticos e teóricos, ainda que não necessariamente anunciados, o vocabulário socioassistencial reúne categorias que definem o público alvo, as garantias efetivadas e as demandas que justificam a intervenção da Política. Portanto, ao privilegiar os conflitos de ordem interpessoal e relacional das famílias pobres, circunscritos como expressões de violência intrafamiliar, em detrimento das repercussões macrossociais, como as violações perpetradas pelo Estado, a Política de Assistência Social, no eixo de atuação 
atribuído à PSE de média complexidade, contribui para o reforço de ações punitivas e de controle, possível a partir da mediação entre o SUAS e instituições do aparato judicial.

$\mathrm{Na}$ perspectiva anunciada do governo e orientações das condutas, defendida por Dardot e Laval (2016), a discussão se volta para a análise da transição da atuação da Política nas expressões de violência, anteriormente detida a segmentos vitimados por situações de violência, para a qualificação generalista do fenômeno circunscrito às famílias - cuja designação agrega componentes estruturais como classe, gênero, etnia, geração e nacionalidade. Trata-se de adensar o debate sobre o fenômeno da violência como campo de intervenção da Política de Assistência Social, com o intuito de problematizar as concepções que o qualificam na esteira das provisões da PSE de média complexidade. 


\section{3.}

\section{A abordagem da violência na Política de Assistência Social - notas sobre a reparação de direitos e o controle punitivo}

A partir do debate sobre a histórica correlação entre estruturas protetivas e punitivas nas protoformas das ações assistenciais e nos contornos contemporâneos da Política de Assistência Social no Brasil, a discussão se volta para a análise dos arranjos normativos que qualificam expressões do fenômeno da violência como campo de intervenção na PNAS/2004. Trata-se de explorar as concepções que informam e os atributos que reivindicam a violência como objeto da Assistência Social, ainda que não reconhecidos, categoricamente, nos documentos normativos da Política.

O percurso da investigação explorou a tendência histórica da Assistência Social em atrelar o fenômeno da violência às famílias em situação da pobreza, a partir do desenho programático reatualizado pela PNAS/2004. Os descaminhos punitivos se anunciam na análise das sanções previstas às famílias que descumprem as condicionalidades impostas pelos Programas de Transferência de Renda Condicionada (PTRC), como o PBF, na produção de indicadores socioassistenciais da PSE, que atribuem dados de violações de direitos às famílias e territórios, nas admissão de práticas de cunho fiscalizador, em atenção às requisições dos órgãos de responsabilização, ainda que conflitantes com a natureza dos serviços socioassistenciais, dentre outros elementos punitivos que se mesclam às garantias protetivas da Política.

De antemão, cabe advertir que o estudo da violência na Política de Assistência Social, pelo prisma da teoria crítica, mobiliza referenciais e categorias distintas das anunciadas nos documentos oficiais, quando não ocultas nas normativas vigentes. O estatuto técnico da Assistência Social não postula uma interpretação teórica do fenômeno, o investimento das produções governamentais direciona um nivelamento dos serviços e programas, com diretivas centradas no planejamento, execução e avaliação das ações socioassistenciais em âmbito nacional.

Portanto, ao se colocar diante do desafio de problematizar o sentido da violência na Política de Assistência Social, o movimento de investigação 
vislumbrou apreender as nuances das tipificações do fenômeno, elementos que caracterizam o escopo da intervenção socioassistencial na PSE de média complexidade. E, tal como o trânsito articulado dos serviços, arrolados do básico ao especial, o enquadramento operacionalizado pela Política se complexifica, ao dispor de um repertório de riscos por violações de direitos vivenciados e/ou perpetrados pelas famílias em situação de pobreza.

É possível afirmar que o recorte do fenômeno fundamenta, ao privilegiar expressões de violência que atravessam as relações familiares e interpessoais, a amplitude e especificidade das ofertas da Política, dispostas nos eixos que estruturam os níveis de complexidade do SUAS. Se o parâmetro que define o público da PSB envolve famílias em situação de vulnerabilidade social decorrente da pobreza, enquanto o público da PSE compreende famílias que vivenciam situações de risco pessoal e social por violações de direitos, a métrica de transição instituída na PNAS/2004 é pautada na capacidade de autoproteção familiar.

Como destacado no capítulo de abertura, as ações assistenciais possuem um elo de conexão histórico com a violência, a considerar as medidas punitivas de disciplinamento determinantes para a consolidação da relação capital-trabalho nos países do capitalismo central, as primeiras iniciativas de proteção social com resquícios autoritários no Brasil, bem como as estratégias de ajustamento contemporâneo, que projetam, por intermédio decisivo da Assistência Social, intervenções coercitivas voltadas para a correção de práticas de violência creditadas aos núcleos familiares em situação de pobreza.

Ao tomar como objeto em análise a versão institucional da Assistência Social, faz-se necessário reconhecer as expressões de violência que forjam um campo próprio de intervenção para a Política a partir de 2004, no limiar entre a reparação de direitos e o controle punitivo exercido pelo Estado. Por assim dizer, postula-se reconhecer a paradoxal relação entre proteção e punição nos arranjos contemporâneos da Política, os quais são instituídos num contexto democrático, marcado por um notório avanço do conservadorismo, porém ainda vigentes sob o signo do Estado de direito. 


\section{1.}

\section{A violência como objeto de intervenção da Política de Assistência Social}

Nas linhas introdutórias da dissertação, as modalidades de atendimento da PNAS/2004 foram detalhadas, de modo a elucidar o desenho normativo da Política e orientar a análise detida ao eixo da PSE de média complexidade. Como anunciado, as expressões de violência, elegíveis para a intervenção socioassistencial, caracterizam situações de risco social e pessoal, que provocam, em consequência, violações de direitos. A definição de risco, a partir de 2004, ascende como categoria central da Política, ao estabelecer o repertório de eventos que justificam as ofertas e aquisições atreladas aos serviços da proteção especial.

Na publicação das Orientações Técnicas da Vigilância Socioassistencial ${ }^{24}$ (2015), a categoria risco é associada à antecipação de determinados eventos, considerando dimensões culturais ou subjetivas que a sociedade mobiliza para reconhecer, avaliar e valorar sua incidência. Para a Assistência Social, a operacionalização do risco decorre de um conjunto de eventos em relação aos quais lhe compete desenvolver esforços de prevenção ou de enfrentamento para redução de seus agravos. A normativa sublinha que, constituem situações de riscos a incidência, ou probabilidade de ocorrência, de

(...) situações de violência intrafamiliar; negligência; maus tratos; violência, abuso ou exploração sexual; trabalho infantil; discriminação por gênero, etnia ou qualquer outra condição ou identidade; situações que denotam a fragilização ou rompimento de vínculos familiares ou comunitários, tais como: vivência em situação de rua; afastamento de crianças e adolescentes do convívio familiar em decorrência de medidas protetivas; atos infracionais de adolescentes com consequente aplicação de medidas socioeducativas; privação do convívio familiar ou comunitário de idosos, crianças ou pessoas com deficiência em instituições de acolhimento; qualquer outra privação do convívio comunitário vivenciada por pessoas dependentes (crianças, idosos, pessoas com deficiência), ainda que residindo com a própria família. (BRASIL, 2015, p.12)

24 Publicação voltada para a sistematização da base conceitual e normativa da Política de Assistência Social, assim como para a disseminação de informações e orientações práticas para a implantação ou organização da Vigilância Socioassistencial nos diferentes níveis de gestão. 
Com efeito, a argumentação que instrui as publicações da Política posiciona a família como o lugar que vivencia e, mutuamente, reproduz o risco, ao elencar expressões de violações comumente alçadas à responsabilização parental, discriminações identitárias e/ou segregação comunitária. Ou seja, manifestações de conflitos individuais, que denotam fragilidades de ordem relacional e, portanto, demandam intervenções que assegurem a preservação e/ou resgate de vínculos familiares como alternativa de suporte aos sujeitos com direitos violados. Atributos valorativos que reatualizam o conservadorismo presente na Política, os quais reforçam um componente moralizador das famílias, tomadas como responsáveis pela proteção irrestrita de seus membros, como também por perpetrar ciclos de violência.

O discurso normativo que orienta a Política de Assistência Social reforça uma compreensão dual de risco, ao considerá-lo enquanto condição vivenciada ou perpetrada - sendo a família o ponto de partida de sua reprodução, enquanto agente ou vítima do contexto violador de direitos. As expressões do fenômeno da violência, por sua vez, comparecem nos tópicos descritivos, reconhecidas como justificativas da condição de risco social e/ou pessoal. Os documentos institucionais particularizam a dimensão do risco como referencial para a intervenção dos serviços, associado, no eixo da PSE de média complexidade, às expressões de violência vivenciadas, decisivamente, pelas famílias em situação de pobreza.

Reside, nesse ponto, o sentido por explorar as categorias mobilizadas pela PNAS/2004, dado o contexto incerto e temerário que as orientações e normativas encerram para as famílias, em particular no trânsito das ações da PSE de média complexidade. Para tanto, a pergunta que suscitou a construção do problema da pesquisa é retomada, a saber: quais concepções orientam e encaminham as expressões de violência reconhecidas como campo de intervenção da Política de Assistência Social?

A indagação remonta, necessariamente, as delimitações conceituais de violência que embasam o estudo, as quais dialogam com as contribuições teóricas desenvolvidas por Michel Misse (1999; 2014; 2016). Faz-se necessário ressalvar, entretanto, que a leitura crítica do autor se detém à violência como problema teórico, enquanto que a pesquisa em curso problematiza o desenho normativo de uma política social, que reivindica a violência como objeto de intervenção - seja na 
perspectiva de uma resposta assistencial às vítimas de uma ação violenta (agressão, exploração sexual, negligência), como uma garantia de reparação aos vitimados por desigualdades da estrutura social (racismo e desigualdades de gênero) ou na promoção de agendas preventivas (campanhas de sensibilização em datas simbólicas). Decerto, a aproximação com as contribuições do autor permite distinguir as definições de violência presentes na Política de Assistência Social, cuja prevalência remete a interpretações que privilegiam ações violentas no âmbito familiar.

Misse (2016) adverte, ao introduzir as ideias dos autores que conceituam violência, que a disputa do conceito aparece com clareza retórica e argumentativa já no próprio recorte do objeto. Tal assertiva é extensiva à apropriação semântica presente na Política em questão, que se pauta pela diretriz da matricialidade sociofamiliar e, na PSE, privilegia famílias em situação de risco por violação de direitos, com destaque para expressões de violência atreladas às relações familiares e interpessoais.

Se para Misse "o recorte do objeto define o viés da construção conceitual" (MISSE, 2016, p. 57), a definição das famílias pobres como público preferencial dos serviços socioassistenciais, e, na PSE, associado às violações de direitos por expressões de violência intrafamiliar, a Política determina os sentidos de violência por ela privilegiados - pautados na construção do referencial de risco, que motivam intervenções de ajuste e correção concomitantes às medidas de proteção às suas vítimas.

No encaminhamento das proposições sobre as abordagens de violência, Misse (2016) aponta autores com os quais estabelece diálogos, com destaque para Slavoj Žižek e Willem Schinkel. Em relação ao primeiro, salienta o movimento de contrarreação à sociologia da ordem, cuja obra Violence: Six Sideways Reflections (2008), ascendeu como uma contundente crítica às produções alinhadas à defesa do Estado capitalista (Misse, 2016). Na concepção de Žižek, uma extensão do conceito de violência baseia-se, fundamentalmente, no argumento de que existe um vínculo inextrincável entre poder, violência e estrutura social - "abstrair desse vínculo a violência física intencional, interpessoal ou coletiva teria o efeito de ocultá-lo e, por conseguinte, de produzir na análise um viés ideológico, cujo efeito poderia também ser interpretado como uma forma de violência” (MISSE, 2016, p. 59). 
Na sequência, Misse aborda as arguições de Schinkel na obra Aspects of Violence: A Critical Theory (2010). Nela, segundo Misse, o autor defende que a violência, como o pato/lebre de Wittgenstein ${ }^{25}$, não tem uma única dimensão, mas várias - esses vários aspectos ou formas da violência ocultam-se mutuamente; quando um emerge, os outros se escondem, e não é possível ver todos os aspectos da violência ao mesmo tempo. Por isso, propõe "(...) abordar aquilo que ele (Schinkel) vê como sendo o único horizonte ontológico comum a todos esses aspectos: a violência como redução do ser" (MISSE, 2016, p. 59).

Misse reconhece afinidades diretas com Schinkel, em especial por ambos sustentarem não um conceito de violência, mas o reconhecimento do caráter mais performático do que de constatação dos usos que dela são feitos (2016). Endossa sua perspectiva, compartilhada por autores brasileiros de renome ${ }^{26}$, ao sustentar a violência não como um conceito, mas como representação social, como parte do objeto em análise. Nesse ponto, retoma a defesa do conceito de acumulação social da violência, como categoria de análise:

Prefiro insistir no conceito de "acumulação social da violência" por meio do qual a violência, sem deixar de ser uma representação social, comparece em seu triplo sentido de práticas representadas e acusadas como de violência interpessoal, de violência estatal e de coercitividade da estrutura social, podendo vir a constituir uma causalidade circular acumulativa, pelos agentes sociais e práticas que desempenham, de tempos em tempos, como procurei mostrar em meus estudos sobre o Rio de Janeiro no século XX (MISSE, 2016, p. 60).

O conceito de acumulação social da violência agrega importantes elementos para a análise desenvolvida sobre a concepção de violência que informa e orienta os serviços da Política de Assistência Social. Postula-se que a relação de causalidade entre as expressões de violência interpessoal, de violência estatal e de coercitividade da estrutura social adensam, sobremaneira, os referenciais para análise das categorias definidas como expressões de violência e violações de direito. De acordo com as normativas do trabalho social com famílias, a intervenção do CREAS prevê:

25 Figura que retrata a cabeça pato-lebre, cujos traços podem ser vistos e compreendidos como um coelho, tanto como se parecem com um pato. O desenho é igual, o que muda é a maneira pela qual é percebido, em outras palavras, os aspectos que são detalhados em cada análise.

26 Machado da Silva (1993) e Maria Stela Grossi Porto (1999). 
O trabalho social com centralidade na família no CREAS visa ao fortalecimento de sua função de proteção e atenção a seus membros, prevenindo, mediando e fortalecendo condições para a superação de conflitos. Essa perspectiva é fundamental para prevenir a recorrência e/ou agravamento de processos que gerem e/ou acentuem situações de violência, abandono, negligência ou qualquer outro tipo de situação de risco pessoal e social, por violação de direitos. Nessa direção, o trabalho social proposto pelo CREAS deve primar pelo acesso das famílias e indivíduos a direitos socioassistenciais e inclusão na rede, tendo em vista o empoderamento e a potencialização de seus recursos e capacidade de proteção (BRASIL, 2011, p. 34).

Em razão dos limites da análise, centradas na experiência da PSE de média complexidade, sublinha-se a relevância de Michel Misse para problematizar a compreensão de violência que direciona as intervenções da Política, tais como as expectativas de proteção delegadas às famílias. A apreensão de violência com enfoque nas ações, como problematizado, limita-se à agressão e ao agressor, fundamentando o processo de incriminação do sujeito transgressor. Lógica que delineia as intervenções da Assistência Social, ao tomar o fato - sob a forma de notificações, denúncias, processos judiciais - como substrato que legitima a demanda, as ações de proteção e judicialização das ocorrências violadoras.

Como defendido por Misse (2014), o acúmulo das expressões de violência, para além da dimensão interpessoal, reafirma a necessidade de se incorporar a violência estatal e a coercitividade da estrutura social, notoriamente ausentes na composição das demandas elegíveis para a atuação da Assistência Social. A categoria reforça o entendimento que a responsabilização dos núcleos familiares atende a uma lógica de controle e criminalização da pobreza, por parte do Estado. Negligenciar o impacto dos indicadores que retratam as violações perpetradas por agentes públicos nas dinâmicas das famílias pobres, além da histórica fragilidade das políticas públicas para assegurar direitos básicos, evidencia o que Misse (2014) denomina como a apropriação unilateral do conceito de violência - fadada ao enquadramento de um determinado segmento, de um dado recorte de família.

A organização de uma gama de serviços direcionados às famílias que, a despeito das condições materiais e objetivas de reprodução e de trajetórias marcadas por processos de desigualdades estruturais, são responsabilizadas por não corresponderem às expectativas de proteção que lhe são imputadas, no âmbito da Assistência Social, justifica a decisiva projeção da categoria risco para a Política. As ocorrências que o motivam - expressões de violências interpessoais e relacionais 
- justificam a adoção de medidas correcionais como recursos próprios do campo socioassistencial, necessárias para garantir a dita reparação dos direitos violados e, em última instância, a capacidade protetiva das famílias.

A condição de risco motivada por situações de violência intrafamiliar admite o atravessamento das instâncias do Sistema de Justiça nas intervenções conduzidas pelos serviços da PSE de média complexidade, posto que a lógica disciplinar, assim como a própria garantia da reparação de direitos, por vezes extrapola os limites de atuação próprios da Política de Assistência Social. O consentimento legitima, decerto, garantias que apenas o campo sociojurídico é capaz de assegurar, bem como reafirma a suspeição quanto ao referencial de cuidado tecido pelas famílias pobres.

Nesse contexto, constatar o privilégio por explorar referências de determinadas categorias, em contraste como o uso descritivo de outras, como violação de direitos e violência, respectivamente, notabiliza o direcionamento político e ideológico que circunda a Política. Explorar a noção de risco atrelado a um recorte específico do fenômeno da violência permite, dentre outras tendências, reforçar a complementariedade entre as ações assistenciais e os ritos de controle punitivo - o que se apresenta como uma reatualização do binômio proteção e punição nos desígnios contemporâneos da Assistência Social.

\section{2.}

\section{A reprodução do controle punitivo nos domínios da proteção social - a dualidade do campo socioassistencial}

Ao problematizar as expressões de violência que definem a estrutura da PSE de média complexidade - como violência física, psicológica, negligência, abandono, violência sexual, trabalho infantil, dentre outras - voltadas aos conflitos de ordem interpessoal e relacional das famílias pobres, em detrimento das repercussões de violência estrutural, a pesquisa sustenta a hipótese que a Assistência Social contribui para o reforço de ações punitivas e de controle direcionadas ao público da aludida Política em particular, assim como para as famílias em situação de pobreza numa escala generalista. 
Parte-se do pressuposto que o modelo de proteção e garantia dos direitos socioassistenciais admite, de forma concomitante, estratégias de disciplinamento, embora assegure princípios e garantias necessárias à reprodução social e defesa de direitos humanos - em que pese a já mencionada regressão dos direitos advindos da relação salarial formal e o avanço da mercantilização das políticas sociais, além da mobilização em prol de agendas progressistas, como o enfrentamento ao trabalho infantil e à violência sexual. A despeito da condição paradoxal que atravessa os quadros da Assistência Social, traços conservadores da Política são permanentemente atualizados, sendo a correlação da violência e pobreza categórica para ilustrar tal assertiva.

Com efeito, a análise assume como referencial os limites do Estado de direito - quer pela perspectiva jurídica, segunda a qual a estrutura discriminatória do poder punitivo opera uma fissura no Estado constitucional de direito na América Latina (ZAFFARONI, 2007), como pelo viés sociológico, que argumenta, em que pese os avanços democráticos conquistados após a vigência do regime ditatorial, não se logrou à efetiva instauração do Estado democrático de direito no Brasil (ADORNO, 1995). A partir das teses de Eugenio Raúl Zaffaroni (2001; 2007) e Sérgio Adorno (1995), a discussão introduz um debate sobre a construção do inimigo no âmbito do direito penal e o exercício do poder punitivo na sociedade brasileira - determinantes para a compreensão do controle e disciplinamento forjados nos domínios da Política de Assistência Social.

A definição dos autores decorre da compreensão que o objeto central da pesquisa empreendida - famílias e indivíduos implicados nos ciclos de violência e atravessados pelas desigualdades de classe, gênero, raça/etnia, geração e nacionalidade - possui elos de aproximação com as proposições teóricas advindas da criminologia crítica e da sociologia. Para Zaffaroni (2007), na América Latina o exercício do poder punitivo dirige-se à contenção de grupos determinados e não à repressão do delito, pautada pela seletividade criminalizante, que forja o dito inimigo como categoria no direito penal. Adorno (1995), por sua vez, sinaliza um cenário de violações de direitos humanos na sociedade brasileira, como produto de uma violência endêmica, radicada nas estruturas sociais, manifesta no comportamento de grupos da sociedade civil, como no de atores incumbidos de preservar a ordem pública. 
Os autores, ao demarcarem nuances e limites do Estado de direito, numa perspectiva continental e regional, adensam a discussão encadeada no capítulo anterior, ao enfatizarem atravessamentos presentes na relação entre violência e cidadania, além da contribuição para a interpretação teórica do fenômeno da violência na contemporaneidade. Nesse sentido, é possível articular referências conceituais balizadas por ambos, com destaque para o retorno à abordagem das teses de Michel Foucault, tomado ponto de convergência entre o debate de Adorno e Zaffaroni.

A discussão dos autores contempla a dimensão histórica e política do Brasil e da América Latina, a partir dos processos de pactuação dos regimes democráticos. Ainda que guardem distinções, considerando as configurações coloniais e da lógica escravocrata nos países latino-americanos, é possível reconhecer, nos traços da sociedade brasileira, sublinhados por Adorno, tendências da inserção na região dita marginal, tal como postulado por Zaffaroni (2001). Para o último, a dimensão da violência vivenciada e sua trágica progressão na América Latina é o ponto de partida para a tomada de decisão de "retirar-se" do sistema planetário, e, assim, “(...) assumir a condição marginal é um pressuposto iniludível para se tentar sua superação" (ZAFFARONI, 2001, p. 7).

Adorno (1995) argumenta que a história da sociedade brasileira pode ser narrada como uma história social e política da violência. Para o autor, em diferentes espaços e camadas do tecido social, disseminam-se formas díspares da violência, vivenciadas e reproduzidas por distintos e diversos atores e instituições. No artigo intitulado "a violência na sociedade brasileira: um painel inconcluso em uma democracia não consolidada", o autor sistematiza um amplo quadro de análise, amparado por dados e sínteses contundentes, cuja crítica é potente por desvelar questões que “(...) clarificam a violência na moderna sociedade brasileira" (ADORNO, 1995, p. 304).

Na obra O Inimigo no Direito Penal, Zaffaroni (2007) aborda a dialética entre o Estado de direito e o de polícia, traduzida, no campo penal, na admissão do tratamento punitivo a seres humanos privados da condição de pessoas. Assinalados como inimigos da sociedade e, por conseguinte, sujeitos alijados da imposição de sanções dentro dos limites do direito penal liberal - “(...) privados das garantias que hoje o direito internacional dos direitos humanos estabelece universal e 
regionalmente" (ZAFFARONI, 2007, p. 11). A hipótese do autor assenta-se na compreensão que o tratamento diferenciado de seres humanos privados do caráter de pessoas é próprio do Estado absoluto, de modo a instaurar uma contradição permanente entre a doutrina jurídico-penal que admite e legitima o inimigo e os princípios do Estado de direito (ZAFFARONI, 2007).

Adorno, ao dimensionar aspectos que ampliam o referencial da violência, comumente associada ao ato e ao autor de crimes, aponta características da tradição autoritária que atravessa e reveste as relações de poder na sociedade brasileira. A alusão à tese de Zaffaroni (2007) é fundamental para a compreensão dos processos que forjam as identidades suspeitas, nos quais a violência e seus riscos consequentes são materializadas naqueles que corporificam o inimigo - cujas características remontam aspectos estruturais que traduzem, nas palavras de Adorno (1995), as fraturas da desigualdade social no Brasil.

Ao discorrer sobre aspectos da violência no país, expressos, como pontuado, num painel inconcluso, Adorno (1995) sintetizou um amplo espectro do fenômeno da violência, embasado por dados estatísticos e análises da conjuntura vivenciada à época. Numa tentativa de aproximar e atualizar o quadro, traçado pelo autor na década de 1990, os tópicos serão ilustrados com registros contemporâneos, obedecendo, no entanto, as categorias definidas por Adorno. Para efeito da discussão, aqui travada, serão privilegiados os seguintes eixos: violência criminal versus violência policial; e, violência nas instituições de reparação social.

Ao situar a discussão sobre violência criminal, Adorno (1995) destaca que a resposta estatal diante do crescimento da criminalidade violenta recorre, proporcionalmente, a um controle violento da ordem pública, cujo saldo retrata o emprego desmedido das forças policiais repressivas. Afirma que as políticas públicas de segurança determinam diretrizes às agências policiais, no sentido de conter a violência de modo exacerbado, o que incorre no comprometimento de vidas de indivíduos suspeitos de perpetrarem crimes. Adorno (1995) avaliou, à época, a escalada ímpar da violência policial, tendo como pressuposto os relatórios de mortes extrajudiciais praticadas por agentes de segurança, sob a justificativa de estrito cumprimento do dever ou resistência à voz de prisão.

O cenário político e social contemporâneo é emblemático por caracterizar o recrudescimento da violência perpetrada por agentes/agências estatais. A escalada 
midiática da violência polarizou um debate público, atravessado por posições dualistas e, em essência, antidemocráticas. $\mathrm{O}$ apelo por segurança imprimiu os contornos repressivos das agendas governamentais em disputa, sendo decisivas para a composição das pactuações e programáticas eleitorais vigentes.

O Estado do Rio de Janeiro, assim como nos registros históricos observados por Adorno (1995), traduz e projeta, em âmbito nacional, a repercussão das plataformas de segurança que despontam como alternativas para a contenção punitiva (e atrozes) da criminalidade. As declarações do atual Governador do Estado, Wilson Witzel, em entrevista ao jornal Estado de São Paulo ${ }^{27}$, após ter sido declarado eleito, são contundentes:

[Houve casos de pessoas que morreram porque estavam com uma furadeira ou um guarda-chuva. Os policiais se confundiram. Atira primeiro e verifica depois?]

Quem atirou é um incompetente, não devia ter atirado. Não estava preparado. Se fizer um curso de sniper, vai estar preparado para identificar quem está de guarda-chuva.

[O senhor falou em colocar snipers em helicópteros. Os moradores das favelas ficam em pânico nessas operações]

E os cinco bandidos de fuzil atirando para tudo quanto é lado não contam, não? A errada é a polícia?

[Da polícia o cidadão espera a conduta correta; do bandido não...]

O correto é matar o bandido que está de fuzil. A polícia vai fazer o correto: vai mirar na cabecinha e... fogo! Para não ter erro.

[Se matar bandido reduzisse a violência, o Rio seria um paraíso...]

Então não está matando, não é? Está deixando de matar.

A partir da sistematização de um breve levantamento ${ }^{28}$ no acervo de dados do Instituto de Segurança Pública do Estado do Rio de Janeiro (ISP), foi possível constatar o incremento da taxa de letalidade das ações policiais, quando comparado aos cinco primeiros meses dos últimos quatro anos:

27 Acesso em 01/07/2019, disponível em: https://politica.estadao.com.br/noticias/eleicoes,apolicia-vai-mirar-na-cabecinha-e-fogo-diz-novo-governador-do-rio, 70002578109

28Acesso em 01/07/2019, disponível em: https://public.tableau.com/views/ SriesHistricas/Resumo ?:embed=y\&:embed_code_version=3\&:loadOrderID=

\&:display_count=yes $\&$ :origin=viz_share_link 
Figura 1 - Tabela de dados - morte por intervenção de agente do Estado. Tabela de dados - Morte por intervenção de agente do Estado - Área: Todos

\begin{tabular}{|c|c|c|c|c|c|c|c|c|c|c|c|c|c|}
\hline & jan & fev & mar & $a b r$ & mai & jun & jul & ago & set & out & nov & dez & Total \\
\hline 2003 & 90 & 111 & 113 & 125 & 96 & 86 & 100 & 94 & 102 & 132 & 75 & 71 & 1.195 \\
\hline 2004 & 77 & 65 & 81 & 68 & 103 & 75 & 69 & 90 & 86 & 114 & 90 & 65 & 983 \\
\hline 2005 & 72 & 59 & 94 & 67 & 93 & 116 & 90 & 119 & 111 & 105 & 95 & 77 & 1.098 \\
\hline 2006 & 66 & 70 & 92 & 101 & 89 & 102 & 88 & 124 & 75 & 87 & 88 & 81 & 1.063 \\
\hline 2007 & 117 & 90 & 111 & 131 & 137 & 108 & 81 & 127 & 125 & 113 & 110 & 80 & 1.330 \\
\hline 2008 & 109 & 109 & 140 & 147 & 147 & 105 & 62 & 30 & 62 & 74 & 81 & 71 & 1.137 \\
\hline 2009 & 94 & 75 & 103 & 102 & 80 & 107 & 87 & 75 & 82 & 93 & 76 & 74 & 1.048 \\
\hline 2010 & 77 & 62 & 81 & 102 & 109 & 74 & 58 & 30 & 34 & 71 & 102 & 55 & 855 \\
\hline 2011 & 61 & 39 & 68 & 68 & 74 & 62 & 37 & 18 & 23 & 20 & 33 & 20 & 523 \\
\hline 2012 & 38 & 35 & 38 & 45 & 41 & 19 & 49 & 44 & 15 & 31 & 38 & 26 & 419 \\
\hline 2013 & 29 & 29 & 38 & 37 & 41 & 26 & 36 & 27 & 41 & 38 & 31 & 43 & 416 \\
\hline 2014 & 50 & 56 & 46 & 37 & 53 & 45 & 57 & 45 & 49 & 45 & 63 & 38 & 584 \\
\hline 2015 & 65 & 83 & 54 & 59 & 44 & 44 & 61 & 49 & 58 & 52 & 47 & 29 & 645 \\
\hline 2016 & 53 & 49 & 61 & 78 & 84 & 75 & 74 & 74 & 88 & 87 & 94 & 108 & 925 \\
\hline 2017 & 98 & 85 & 123 & 80 & 97 & 97 & 63 & 70 & 106 & 98 & 125 & 85 & 1.127 \\
\hline 2018 & 157 & 102 & 109 & 101 & 145 & 155 & 130 & 176 & 108 & 127 & 136 & 88 & 1.534 \\
\hline 2019 & 159 & 145 & 132 & 124 & 171 & & & & & & & & 731 \\
\hline
\end{tabular}

Nesse contexto, é imperativo retomar o debate de Zaffaroni (2007), em especial quanto às táticas vigentes de contenção punitiva. $\mathrm{O}$ autor recompõe o histórico do chamado direito penal do inimigo, no qual repousa o tratamento diferenciado dos autores de crimes, idealizado, inicialmente, para os terroristas. Para a doutrina jurídico-penal, o direito deveria habilitar o poder punitivo de uma maneira para os cidadãos e de outra para os inimigos, reservando o caráter de pessoa, tão somente, para os primeiros. O autor adverte que "ao operar a distinção dos cidadãos (pessoas) e inimigos (não pessoas) estamos nos referindo a seres humanos que são privados de certos direitos fundamentais, em razão de não serem mais considerados pessoas" (ZAFFARONI, 2007, p. 162).

Ao problematizar o que denominou como a "inevitável quebra do Estado de Direito" (ZAFFARONI, 2007, p. 163), o autor questiona a definição e identificação de quem se julga inimigo, considerando que, a depender da emergência e necessidade, suspende-se ou designa-se como não-pessoa quem considerar oportuno. A anulação do princípio do Estado de direito reside, pois, na limitação do poder nas mãos de “(...) um soberano que individualiza inimigos por decisão política e contra quem não se pode oferecer resistência” (ZAFFARONI, 2007, p. 164). Em complemento, indaga a extensão dos riscos quando o Estado de direito é violado nos fatos e no direito, tal como na América Latina (ZAFFARONI, 2007).

Para o autor, é possível observar que na região, as medidas de contenção, postuladas apenas para os designados inimigos, são aplicadas a todos os suspeitos - "trata-se a todos como inimigos. Essas medidas de contenção são aplicadas 
automaticamente a todos aqueles suspeitos de serem infratores" (ZAFFARONI, 2007, p. 164). Com efeito, o penalismo, exercido na América Latina, excede os limites da contenção do inimigo, concebida, por um viés restrito na doutrina jurídico-penal, para os ditos terroristas. Segundo o autor, o direito penal na América Latina legitima as medidas de pura contenção para os indivíduos socialmente identificados como perigosos, de modo que o poder punitivo desloca a lógica de controle para todos aqueles considerados suspeitos e infratores e, portanto, inimigos.

A contenção punitiva, postulada por Zaffaroni, que desumaniza e impõe a suspensão do rito democrático próprio do Estado de direito, foi detalhada por Adorno (1995) no tópico violência nas instituições de reparação social. Ao traçar o panorama do sistema penitenciário no Brasil, o autor detalha as cruéis condições das prisões e demais instituições de controle. Sublinha, como dados alarmantes, a superlotação e a explosão de motins e rebeliões, sendo o Massacre do Carandiru, em 1992, emblemático para definir a barbárie do controle punitivo no país.

A fotografia da rebelião - 111 presos após a invasão da Polícia Militar à Casa de Detenção de São Paulo -, corrobora o argumento central de Adorno (1995), o qual questiona a efetiva instauração do Estado democrático de direito no Brasil após a vigência do regime ditatorial, assim como desvela o penalismo que toma o lugar do inimigo como não-pessoa, em concordância com a tese de Zaffaroni (2007).

\begin{abstract}
Sem a devida responsabilização daqueles que praticaram crimes contra a humanidade, estabeleceu-se uma expectativa de que a violação dos direitos daqueles que são socialmente considerados "não sujeitos", de uma perspectiva moral, continuaria a ser admitida. O que mudou foi o alvo do arbítrio. Se no passado eram os inimigos do regime que poderiam ser impunemente eliminados, no presente são aqueles que, por força de uma desigualdade profunda e persistente, são vistos como potencial ameaça ao status quo. O Massacre do Carandiru talvez constitua apenas um símbolo destacado da incompletude de nossa transição. Seja pela brutalidade que marcou aquele momento, seja pela negligência das diversas instâncias de aplicação da lei em reconhecerem o abuso e responsabilizarem os que o praticaram. (VIEIRA, 2015, p. 17)
\end{abstract}

Ao transpor para o contexto atual, é coerente afirmar que a estrutura punitiva agudizou as expressões da desumanização, face às características genocidas de contenção, e não de disciplinamento, que, persistentemente, imperam no sistema penal latino-americano (ZAFFARONI, 2001). À semelhança dos 
exemplos $^{29}$ citados por Adorno (1995), o censo penitenciário nacional, publicado em 2016, retratou que a taxa de aprisionamento no Brasil aumentou em 157\%, no período compreendido entre 2000 a 2016 - “em 2000 existiam 137 pessoas presas para cada grupo de 100 mil habitantes. Em junho de 2016, eram 352,6 pessoas presas para cada 100 mil habitantes" (BRASIL, 2016, p. 12).

Figura 2 - Evolução da taxa de aprisionamento no Brasil entre 2000 a 2016

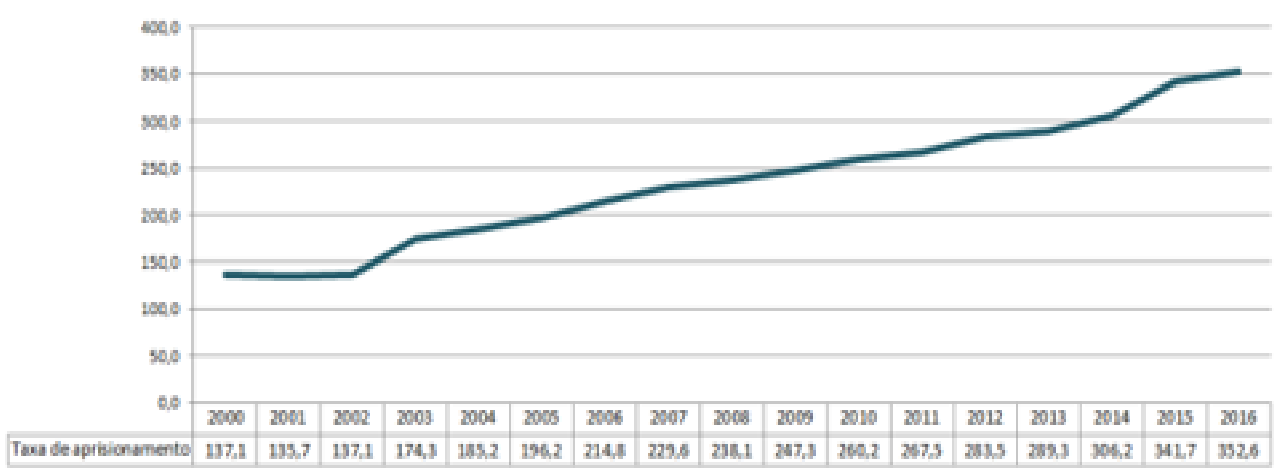

Fonte: Levantamento Nacional de Informaçōes Penitenciárias - Infopen, dezembro de cada ano; DATASUS.

Figura 3 - Pessoas privadas de liberdade por natureza da prisão e tipo de regime

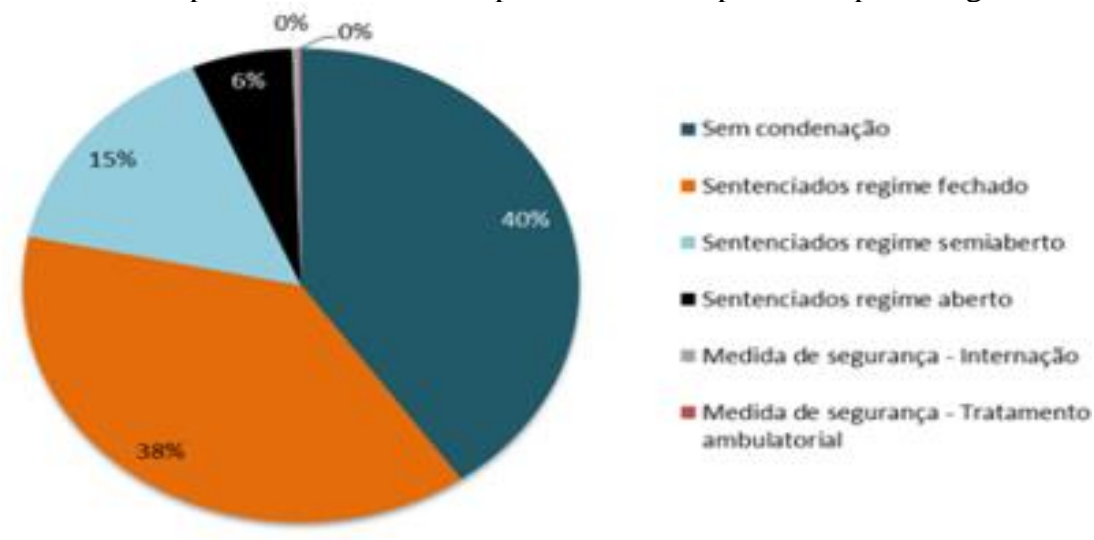

Fonte: Levantamento Nacional de Informaçoes Penitenciárias - Infopen, Junho/2016.

O primeiro gráfico ilustra a evolução da taxa de aprisionamento no país, sendo contundente ao envidar o recrudescimento punitivo apontado por Zaffaroni (2007). Enquanto o segundo gráfico ${ }^{30}$ adentra na caracterização das pessoas privadas de liberdade, considerando a natureza da privação e o tipo de regime. 
Constata-se que $40 \%$ dos indivíduos presos no Brasil não foram julgados e condenados, percentual que supera o quantitativo de presos sentenciados com a medida privativa de liberdade $-38 \%$. Embora os dados dimensionem o panorama nacional, Zaffaroni (2007) assevera tratar-se de uma prática de toda a América Latina, no tocante aos indivíduos reduzidos à condição de prisioneiros,

Na América Latina as medidas de contenção para os inimigos ocupam quase todo o espaço de ação do sistema penal em seu aspecto repressivo, por via da chamada prisão ou detenção preventiva, provisória. (...) este dado é fundamental para extrair conclusões acerca do alcance da proposta de legitimação de um eventual tratamento penal diferenciado na América Latina, pois esta seletividade é praticada em nossa região por efeito da criminalização. Porém, uma vez posto em marcha este processo, todos passam a ser tratados como inimigos, através de puros confinamentos de contenção, prolongados ou indefinidos. (ZAFFARONI, 2007, p. 109)

O quadro comparativo desenvolveu, por meio dos eixos extraídos do painel de Adorno, pontos de aproximação entre os autores indicados, partindo da premissa quanto à centralidade do Estado de direito - sem dúvida, dos seus limites e fragilidades diante dos imperativos da razão punitiva. O exercício do diálogo entre distintas perspectivas analíticas, a jurídica e a sociológica, adensaram, sobremaneira, o referencial teórico que orientou o processo investigativo. Em especial, por agregar elementos à discussão dos contornos punitivos que a relação entre o executivo e o judiciário, particularizados no SUAS e no Sistema de Justiça, apresentam na atualidade.

Ao compor uma teia de cenários de violências, aqui foram destacados apenas dois tópicos, Adorno (1995) situa elementos imbricados, que sustentam uma via de normalidade e passividade, com ampla aceitação entre diferentes grupos da sociedade brasileira. $\mathrm{O}$ autor problematiza as alternativas forjadas para a resolução de conflitos, seja na órbita das relações entre classes, como nas relações subjetivas, ou seja, traz à tona a problemática da violência enraizada na sociedade e na cultura, sem desconsiderar, entretanto, os planos da política e do Estado (ADORNO, 1995).

Reitera que a identificação da violência limitada à dimensão política e do Estado é insuficiente para a interpretação de uma conjuntura que, a despeito da transição democrática, segue marcada por violações de direitos humanos, ainda que os dispositivos constitucionais asseverem garantias democráticas, no marco do Estado democrático de direito. A defesa do autor enfatiza que 
(...) a problemática da violência no plano da sociedade e da cultura, compreendendo suas conexões com o poder político estatal, requer problematizar a complexidade do social, quer dizer dos diferentes eixos de poder que o atravessam, que realizam a dominação, que convergem para o Estado e que suscitam a formação de ideologias autoritárias e discriminatórias. Essa perspectiva reclama considerar a problemática da continuidade autoritária no interior do processo de transição democrática. (ADORNO, 1995, p. 325).

O autor orienta, portanto, a ampliação do repertório mobilizado para o estudo das expressões de violência definidas como campo de intervenção da Assistência Social, de modo a embasar uma análise que permita a aproximação com a complexidade do fenômeno. Os questionamentos acerca do desenho normativo da Política ${ }^{31}$, o qual privilegiaria expressões da violência intrafamiliar, exercitou o diálogo com os referenciais do autor, ao incorporar distintas dimensões que particularizam a violência no Brasil.

Em complemento, Adorno (1995) recupera a expressão "autoritarismo socialmente implantado" para esmiuçar a continuidade autoritária, a ausência de rupturas, ainda que a forma democrática tenha sido institucionalizada no plano formal. Na avaliação do autor, a configuração histórica da sociedade brasileira, marcadamente autoritária, explicita “(...) o espectro de uma violência desmedida, que se espraia por todos os seus poros" (ADORNO, 1995, p. 327). O lugar do autoritarismo faz referência ao modo pelo qual a sociedade brasileira encontra-se estratificada e hierarquizada, amparada, contudo, em elementos que a diferencia de outras sociedades latino-americanas - razão que justifica, por ora, o distanciamento das proposições de Zaffaroni (2007).

O primeiro traço de distinção remonta sua rigidez, considerando que, mesmo que a cordialidade seja um traço constitutivo da cultura brasileira, o autor afirma que ela somente se manifesta na medida em que cada qual reconheça seu lugar (ADORNO, 1995). Em seguida, reforça sua amplitude, ao passo que a rigidez hierárquica organiza tanto as relações entre classes sociais quanto as relações subjetivas - ilustra que esse padrão desponta no plano da vida cotidiana, como atravessa as relações sociais, independente dos atores envolvidos. E, na sequência, a heterogeneidade, na medida em que o dominante em determinada região da existência social pode se traduzir como dominado em outra (ADORNO, 1995).

31 Em destaque no Capítulo III. 
A partir dessas formulações, o autor sintetiza a existência de um pluralismo enraizado no social, que “(...) torna possível a existência de jogos heteronômicos de poder entre diferentes pessoas, grupos e classes sociais, jogos que atravessam os mais diferentes contextos, espaços e objetos" (ADORNO, 1995, p. 329). Tal assertiva sintetiza, assim, o movimento explorado para a análise da Política de Assistência Social, considerando que o campo delimitado para a intervenção, hoje voltado às manifestações da violência, com prevalência das relações familiares e interpessoais, é marcado por disputas de poder que atravessam a totalidade das relações, com repercussões distintas, a depender dos lugares e posições demarcadas e, permanentemente, em disputa.

Nesse ponto da análise, Adorno inicia o diálogo com Foucault, ao tomar como referência o conceito de micropoderes, os quais, dispersos por todo o tecido social, determinam dominantes e dominados, agressores e vítimas. Para Adorno (1995), os micropoderes podem traduzir o monopólio de pequenos ou grandes privilégios, materializados em vantagens de distintas ordens, a partir da dinâmica das relações estabelecidas por pessoas, grupos e classes sociais. Sinaliza, portanto, processos que remetem a práticas e discursos que coexistem, relacionando, necessariamente, o debate da violência ao poder.

No livro Vigiar e Punir - nascimento da prisão, Foucault (2014) discorre sobre a evolução das legislações penais, com destaque para os métodos e técnicas coercitivas adotadas como ritos de punição. $\mathrm{O}$ direito penal moderno opera, nas palavras do autor, um novo poder de julgar, constituído a partir de um dado saber, técnicas e discursos científicos que se formam e se entrelaçam nos domínios da prática do poder de punir (FOUCAULT, 2014).

Aqui o objetivo do livro é retomado, ao reivindicar a história da alma moderna em julgamento, com a ressalva, porém, que o estudo não se centrou na análise dos mecanismos punitivos detidos, unicamente, em seus efeitos repressivos. O autor ampliou o referencial de análise dos ritos punitivos, ao "recolocá-los na série completa dos efeitos positivos que eles podem induzir, mesmo se à primeira vista são marginais. Consequentemente, tomar a punição como uma função social complexa" (FOUCAULT, 2014, p. 27).

Foucault (2014) propõe a análise dos sistemas punitivos concretos como fenômenos sociais, dispostos em seus respectivos campos de funcionamento, onde 
a sanção dos crimes não seja o único elemento a ser dimensionado - "as medidas punitivas não são simplesmente mecanismos negativos que permitem reprimir, impedir, excluir (...); estão ligadas a toda uma série de efeitos positivos e úteis que tem por encargo sustentar" (FOUCAULT, 2014, p. 28). Assim, os sistemas punitivos devem ser recolocados a partir da centralidade do corpo, considerando que, a despeito do método imposto de punição - o autor menciona técnicas "suaves" como trancar e corrigir, em oposição aos suplícios - é sempre o corpo que se persegue: "do corpo e das suas forças, da utilidade e da docilidade delas, de sua repartição e de sua submissão" (FOUCAULT, 2014, p. 29).

Com efeito, o debate de Foucault (2014) estabelece um ponto de retorno às teses de Zaffaroni (2001), na medida em que o último sustenta que o verdadeiro e real poder do sistema penal não é o poder repressor, exercido por meio do aparato judicial. Prossegue, dialogando com as inferências de Foucault, pontuando que: “o poder não é mera repressão (não é algo negativo); pelo contrário, seu exercício mais importante é positivo, configurador, sendo a repressão punitiva apenas um limite ao exercício do poder" (Zaffaroni, 2001, p. 125). Alinhado ao pensamento foucaultiano, Zaffaroni (2001) postula que os órgãos do sistema penal exercem uma lógica de controle que se estende para além da feição meramente repressiva, justamente por exercer um poder configurador da vida social.

A interpretação de Zaffaroni (2001) é potente por reconhecer que este poder configurador não se limita às funções exercidas, exclusivamente, pelos órgãos executores do sistema penal. Enfatiza que o sistema penal direciona as práticas de outras agências ou instâncias institucionais, cujo exercício de poder é explicado por discursos distintos, porém com recursos análogos ao aprisionamento e estigmatização (ZAFFARONI, 2001). Em síntese, "uma das facetas perversas do discurso jurídico-formal consiste, portanto, em mostrar o exercício total de poder do sistema penal como esgotado neste ínfimo e eventualíssimo exercício que configura o denominado "sistema penal formal"”' (ZAFFARONI, 2001, p.25).

O viés configurador ou positivo do sistema penal, defendido por Zaffaroni (2001), é fundamental para a análise da Política de Assistência Social e seus postulados desígnios de controle punitivo. É possível afirmar que os direcionamentos que o Sistema de Justiça impõe ao SUAS partem de uma lógica de controle das famílias e dos próprios profissionais, a despeito dos dispositivos e 
pressupostos formais que orientam e respaldam os limites da intervenção socioassistencial. Trata-se, portanto, de um atravessamento que relativiza canais legítimos de articulação previstos na relação entre o Executivo e o Judiciário, o qual se apresenta como pretensamente legítimo, posto que motivado pelo discurso da garantia de direitos, ainda que a preservação dos mesmos incorra na violação de tantos outros princípios legais.

O poder configurador é explicitado não apenas na relação de subsunção imposta pelo Sistema de Justiça ao SUAS, como também no seu reverso, ao passo que os serviços socioassistenciais recorrem a expedientes de cerceamento e disciplinamento das famílias e indivíduos sob seus domínios, ao mobilizar recursos do Judiciário como alternativas de adequação destas às normas do controle burocrático - infligido, não raramente, às custas da exposição das mazelas vivenciadas. É plausível reconhecer, assim, elementos do que Foucault (2014) denominou como tecnologia da alma, considerando que seu controle prescinde da punição corpórea, ao passo que amparadas na lógica do controle seletivo e disciplinador - tal como a relação entre o Sistema de Justiça e órgãos do Poder Executivo, bem como as próprias diretrizes do SUAS são potentes em retratar.

O diálogo entre os autores, Adorno e Zafaroni, possibilitou o estudo de duas perspectivas analíticas distintas, as quais, entretanto, partem de pressupostos semelhantes - os limites do Estado democrático de direito - e convergem nas referências teóricas - a exemplo da centralidade de Michael Foucault para ambos os autores. O exercício de análise agregou, assim, elementos para a avaliação do ciclo da Política de Assistência Social, em que pese o período de formulação, implementação, tipificação dos serviços, produção de indicadores socioassistenciais e formação continuada - etapas que anunciam o processo de maturação da Assistência Social no país.

$\mathrm{O}$ acervo em análise registra avanços fundamentais, haja vista a universalização da cobertura assistencial da PSB, bem como a identidade do SUAS, reconhecido como o sistema de gestão integrada da Política. Os documentos sinalizam, ao mesmo tempo, o alinhamento de lógicas paradoxais, amparadas em categorias que acenam no plano da retórica para a materialização dos direitos sociais, enquanto a operacionalização consente práticas conflitantes - como as 
expressões de violências privilegiadas como campo de intervenção dos serviços socioassistenciais.

É possível reconhecer, nesse contexto, as contribuições de Adorno (1995), ao demarcar o recrudescimento das ações violentas, num contexto de notórios avanços democráticos. As indagações relativas à persistência incrustada das violações de direitos humanos no marco de um Estado democrático, habilitam um exercício similar, quando da articulação com o campo socioassistencial - observase a ampliação das políticas de transferência de renda, a oferta ampliada da PSB e expansão da PSE, porém, no mesmo contexto, iniciativas de cunho moralizador, voltadas para as famílias pobres, ganham vulto e projeção, reatualizando orientações do familismo e de controle operado em conjunto com as instâncias judiciais.

Com efeito, as considerações de Zaffaroni (2001; 2007), em profícuo diálogo com Foucault, reafirmam o poder configurador do sistema penal, que se estende para além do alcance meramente repressivo das penas formais. Se a contenção do inimigo não se materializa, diretamente, nos domínios da Assistência Social, admite-se, contudo, que os elementos que perpassam a construção social do ideário de inimigo são observados nas práticas e sentidos reproduzidos pelo corpo político e técnico que integra a Política, em especial na PSE de média complexidade.

Os serviços socioassistenciais subsidiam práticas que, embora distintas nas nomenclaturas, operacionalizam recursos de controle próprios da esfera penal ampliando o cerceamento para aqueles que, independentemente de qualquer aplicação de penas privativas, encontram-se enredados por práticas de controle cotidianas, em franca suspensão dos pilares do Estado democrático de direito.

\section{3.}

\section{A violação de direitos e a perspectiva reparatória na Política de Assistência Social.}

O eixo protetivo relacionado à PSE de média complexidade foi justificado por dois discursos distintos, no decurso do processo de formulação e operacionalização da PNAS/2004. Explorados a contento no capítulo subsequente, 
a proposta do presente tópico envolve o debate das categorias violação e reparação, considerando a definição em voga da PSE de média complexidade, que sustenta como atributo do PAEFI o acompanhamento especializado de famílias e indivíduos em situação de risco, por violação de direitos. Sentença que substituiu a fragilidade de vínculos relacionais como premissa da intervenção do CREAS, ainda que a preservação das conexões familiares e comunitárias prossiga no rol das garantias socioassistenciais.

A Política de Assistência Social incorporou a categoria violação de direitos como um atributo que particulariza a PSE, no entanto, ao fazê-lo, prescindiu do investimento em qualificá-la enquanto dimensão cara à pauta de debates de Direitos Humanos. As normativas socioassistenciais anunciam as situações violadoras que demarcam o campo de intervenção da Política, que se voltam, decisivamente, às expressões de violência das relações familiares e interpessoais. A apropriação da categoria violação de direitos decorre do detalhamento de suas ocorrências, característica que sugestiona uma perspectiva reparatória peculiar para o campo socioassistencial.

O conceito de reparação possui uma dimensão histórica, impulsionado pela reação internacional às experiências autoritárias que marcaram os regimes ditatoriais. Como pontuado, a história da América Latina compartilha as feridas, ainda expostas, da violência estatal como modo de governo, que, na experiência brasileira, define uma biografia de violações.

A violência aparece como matriz do pensamento autoritário brasileiro, e nos constitui antes mesmo de existirmos como país. Somos sujeitos históricos marcados por processos de assujeitamento e subordinação, um tecido social composto pelo genocídio dos povos originários, pela herança escravocrata, pelos arbítrios da ditadura varguista e por um passado autoritário civil-militar, passado este ainda recalcado pelo corpo social. Entendemos que é necessário problematizar não só o passado ditatorial, mas principalmente as sequelas, os entulhos e as reminiscências autoritárias que ainda seguem afetando nossa sociedade (RODRIGUES et al, 2017, p. 135).

Em 2005, a Organização das Nações Unidas (ONU), aprova a Resolução n 00/147, que dispõe sobre os Princípios Básicos e Diretrizes de Reparação para Vítimas de Violações Graves ao Direito Internacional dos Direitos Humanos e ao Direito Internacional Humanitário. A publicação estabelece medidas de restituição 
perante as violações de Direitos Humanos, a partir da definição do conceito de vítima e reparação, a conferir:

8. Para fins do presente documento, vítimas são pessoas que individualmente ou coletivamente sofreram danos, inclusive lesões físicas ou mentais, sofrimento mental, perdas econômicas ou deterioração significativa de seus direitos fundamentais, por atos ou omissões que constituam violações graves ao Direito Internacional dos Direitos Humanos e ao Direito Internacional Humanitário. Quando apropriado, e conforme a lei nacional, o termo "vítima" também inclui a família próxima ou os dependentes da vítima e pessoas que sofreram danos diretos ao intervirem em auxílio às vítimas em sofrimento ou para evitar a vitimização.

9. Uma pessoa será considerada vítima independente se o perpetrador da violação for identificado, preso, processado ou condenado e independente da relação familial entre o perpetrador e a vítima.

15. Reparação adequada, efetiva e imediata é necessária para promover a justiça fornecendo indenização pelas violações graves ao Direito Internacional dos Direitos Humanos e ao Direito Internacional Humanitário. A reparação deve ser proporcional à gravidade das violações e ao dano sofrido. De acordo com suas leis nacionais e obrigações legais internacionais, um Estado deve fornecer reparação às vítimas por atos ou omissões que podem ser atribuídos a ele e constituem violações graves ao Direito Internacional dos Direitos Humanos e ao Direito Internacional Humanitário. Em casos em que uma pessoa física, uma pessoa jurídica ou outra entidade esteja sujeita a reparar uma vítima, tal parte deve fornecer reparação para a vítima ou compensar o Estado caso o Estado já tenha fornecido reparação à vítima. (BRASIL, 2010c, p. 457)

Ao retomar o debate acerca da violação de direitos e encaminhamentos de reparação no âmbito da PSE de média complexidade, é possível reconhecer a importância da pauta protetiva sustentada pela Política. Enquanto parte das respostas da esfera estatal, a Assistência Social investiu na defesa de segmentos e agendas de mobilização significativas, como os embates públicos em torno do trabalho infantil, da violência sexual e da pessoa em situação de rua. Exemplos de uma atuação que reconhece a posição política da vítima, bem como reivindica medidas de reparação, por parte do conjunto das políticas públicas - em consonância com as prerrogativas recomendadas pela ONU.

Contudo, a Política admite, de forma concomitante, a centralidade das intervenções na família, tomada como vítima e autora de violações, nos contextos de violência destacados como próprios de seu terreno de atuação. As violações de direito afeitas ao campo socioassistencial, em sua maioria, projetam uma perspectiva de reparação assentada na correção de seus perpetradores, detida ao disciplinamento das relações familiares e controle dos contextos de risco 
autoprovocados pelos sujeitos. As seguranças socioassistenciais se voltam, em consequência, para o fortalecimento da capacidade protetiva das famílias - atributo anunciado em todos os documentos do ciclo da PNAS/2004 32.

Neste cenário, a discussão exercita o diálogo com Coimbra e Scheinvar (2012), autoras que problematizam a banalização contemporânea das subjetividades punitivo-penais no Brasil. Em complemento, argumentam que "interessa-nos pensar as formas de subjetivação por meio das quais a sociedade brasileira entende ser possível transformar o que lhe provoca descontentamento ou desespero no cotidiano" (COIMBRA et al, 2012, p. 60). As autoras questionam os discursos de proteção, a organização de um conjunto de leis que operam o controle sob a justificativa de defesa de segmentos tidos como frágeis ou necessitados.

Segurança é a palavra de ordem, sempre associada à proteção. A quem se protege? Quem está inseguro? Quem são os necessitados? Segurança como contenção dos necessitados, em nome da sua proteção: esta é a perspectiva de muitos atendimentos a crianças e jovens quando recusam a escola, os seus espaços de convivência, quando se dedicam a atividades interditadas moralmente e são declarados perigosos. A intervenção com base em leis protetivas não altera a condição de vida dos perigosos, dirige-se com ênfase a coibi-los na expectativa de comportamentos aceitáveis (COIMBRA e SCHEINVAR, 2012, p.61).

A Política de Assistência Social segue a tendência de institucionalizar um marco protetivo, amparado em referenciais sólidos, como a perspectiva de reparação ante violações de Direitos Humanos, tanto quanto operacionaliza modalidades de intervenção assentadas em práticas de controle. A Resolução da ONU ampara definições de violações que remetem à esfera privada, contudo, destacam o lugar decisivo do Estado como instância transgressora de garantias e pressupostos fundamentais do direito à vida. Portanto, se o referencial de violações de direitos e proteção da Política se concentra na família, como as normativas da PSE de média complexidade tendem a endossar, a lógica dos direitos socioassistenciais é passível de questionamentos, na direção daqueles levantados pelas autoras.

As problemáticas, abordadas ao longo da dissertação, a respeito do cenário de violações privilegiado pela Política de Assistência Social, na dinâmica da PSE

32 Afirmação que resulta da pesquisa desenvolvida. A análise detalhada será apresentada no Capítulo III. 
de média complexidade, destacam um recorte do fenômeno da violência que negligencia aspectos estruturais, apontando, justamente, a ausência do reconhecimento do Estado como um dos principais violadores de Direitos Humanos no Brasil. Em adição ao panorama retratado no tópico anterior, o debate se volta aos indicadores de violência do país - dados que colocam em questão a construção do ideário de segurança e dos sujeitos perigosos na sociedade brasileira.

Segundo o Atlas da Violência 2019, publicado pelo Instituto de Pesquisa Econômica Aplicada (IPEA) e pelo Fórum Brasileiro de Segurança Pública (FBSP), em 2017, foram registrados no Sistema de Informações sobre Mortalidade do Ministério da Saúde (SIM/MS) 65.602 homicídios no Brasil, o que equivale a uma taxa de, aproximadamente, 31,6 mortes para cada cem mil habitantes. De acordo com a publicação, trata-se do maior nível histórico de letalidade violenta intencional no país.

No tocante aos homicídios destacados por ciclo geracional, a pesquisa constatou que, em 2017, 35.783 jovens foram assassinados no Brasil - número que representa uma taxa de 69,9 homicídios para cada 100 mil jovens no país, taxa recorde nos últimos dez anos. Ao destacar os registros de letalidade por faixa etária, o documento informa que homicídios foram a causa de 51,8\% dos óbitos de jovens de 15 a 19 anos; de 49,4\% para pessoas de 20 a 24; e de 38,6\% das mortes de jovens de 25 a 29 anos.

De acordo com o estudo, tal panorama indica o homicídio como a principal causa de mortes entre os jovens brasileiros em 2017. No período entre 2016 e 2017, o Brasil registrou aumento de 6,7\% na taxa de homicídios de jovens e, na última década, esse percentual passou de 50,8 por grupo de 100 mil jovens em 2007, para 69,9 por 100 mil em 2017 - o que representa um aumento de 37,5\% nos indicadores de letalidade de abrangência nacional.

No que se refere ao recorte de gênero, os indicadores de letalidade violenta da pesquisa encontram-se fortemente relacionados ao sexo masculino e ao grupo etário dos jovens de 15 a 29 anos. A publicação, ao se deter, especificamente, no grupo dos homens jovens, indicou que a taxa de homicídios por 100 mil habitantes chegou a 130,4 em 2017. E, dos 35.783 jovens assassinados em 2017, 94,4\% (33.772) eram do sexo masculino. 
O Atlas da Violência 2019 monitorou a evolução dos indicadores de letalidade violenta de mulheres, tendo constatado um crescimento expressivo de $30,7 \%$ no número de homicídios de mulheres no país durante a década em análise (2007-2017), bem como no último ano da série, que anotou um aumento de 6,3\% em relação ao anterior (2016). Ainda sobre a violência contra a mulher, o documento aponta que, entre 2007 e 2017 decorre um aumento de 20,7\% na taxa nacional de homicídios de mulheres, quando esta passou de 3,9 para 4,7 mulheres assassinadas por grupo de 100 mil mulheres.

Neste aspecto, a publicação reporta, ainda, o atravessamento da desigualdade racial, a partir da comparação entre mulheres negras e não negras vítimas de homicídio. Enquanto a taxa de homicídios de mulheres não negras teve crescimento de 1,6\% entre 2007 e 2017, a taxa de homicídios de mulheres negras cresceu 29,9\%. Em relação aos homens, o documento sinaliza que, em 2017, 75,5\% das vítimas de homicídios foram indivíduos negros ${ }^{33}$, sendo que a taxa de homicídios por 100 mil negros foi de 43,1 , ao passo que a taxa de não negros ${ }^{34}$ foi de 16,0 .

Por fim, o Atlas da Violência 2019 assinala tendências que descrevem o perfil dos homicídios no país. Ao tomar como parâmetro raça/cor, o padrão de vitimização indica a superioridade dos homicídios entre os homens e mulheres negros (as), em relação a homens e mulheres não negros, alcançando 73,1\% para homens e 63,4\% para as mulheres negras. Ao dispor do quesito escolaridade, o estudo indica que a maior parte dos homicídios vitimam indivíduos com baixa escolaridade, que cursaram até o segundo ciclo do ensino fundamental incompleto.

O retrato exposto adentrou em expressões cabais de violência na sociedade brasileira, sem a pretensão de esgotá-lo ou estabelecer paralelos entre as dimensões macro e micro do fenômeno. A argumentação envolveu um cenário de problemáticas que atravessam o cotidiano dos serviços socioassistenciais, por vezes, sobrepujados por ocorrências pontuais, como as requisições burocráticas dos programas e projetos, na PSB, ou imposição de visitas domiciliares e

33 O Atlas da Violência, versão 2019, definiu como a soma de indivíduos pretos ou pardos, segundo a classificação do IBGE, utilizada também pelo SIM/MS.

34 Como a nota anterior, a definição de não negros contemplou brancos, amarelos e indígenas. 
acompanhamentos compulsórios determinados por órgãos do Sistema de Justiça, no âmbito da PSE de média complexidade.

Os impactos dos indicadores de violência estrutural atravessam de forma particular as trajetórias das famílias pobres - ao abreviar biografias, encerrar projeções e incutir a necessidade de adequação às condutas normalizadas. Os encaminhamentos da Política de Assistência Social, em especial na PSE de média complexidade, avançam na direção do reforço de padrões protetivos, assentados numa dita capacidade naturalizada a ser exercida pelas famílias - a despeito de toda sorte de ocorrências violadoras que as acometem.

A análise dos documentos, em destaque no Capítulo III, evidencia a dualidade de práticas de proteção e correção reproduzidas pela Política, com singulares repercussões para o desenho normativo da PSE de média complexidade, a considerar o reforço de medidas de proteção sob responsabilidade das famílias e dos termos da relação intersetorial com o Sistema de Justiça. Em síntese,

Em nosso país a prática assistencial-punitiva tem atravessado sua história. Podemos pensar no movimento de internação de crianças e adolescentes, predominante no século XX, e no atendimento dirigido a esta população nos conselhos tutelares deste início do século XXI. Todos estes exemplos de políticas de assistência têm forte componente de criminalização da pobreza, já que desqualificar as famílias que divergem do modelo instituído é uma forma de criminalização. Percebemos nestas políticas um forte componente disciplinar. Entretanto, a intervenção do Estado na vida social não pode ser mais vista de forma isolada, ou apenas pelo enfoque estatal. Existem diferentes fluxos na tecnologia de poder contemporâneo. Na sociedade na qual predominavam os dispositivos disciplinares, buscavam-se desvios a serem corrigidos, falhas a serem reparadas, tendo uma norma como modelo-padrão. Hoje, busca-se um risco a ser contido, uma virtualidade a ser capturada. Transgressões não são mais necessárias. O poder punitivo está lado a lado da normalização do normal, controlando, disciplinando, sugando. (NASCIMENTO e RODRIGUES, 2012, p. 201). 
4.

\section{A violência nos documentos da PNAS/2004 - análise do marco protetivo atribuído à PSE de média complexidade}

O presente capítulo compreende o percurso metodológico da pesquisa e a análise dos documentos que normatizam a PSE de média complexidade. Em diálogo com os tópicos anteriores, o estudo reuniu produções do acervo da Assistência Social, de modo a contemplar o registro da temática violência nos escritos das últimas duas décadas da Política. Os documentos que compõem o ciclo da PNAS/2004 dão forma a um movimento de institucionalização inédito para o campo socioassistencial, a considerar o histórico de resistência em pautar a Assistência Social na esfera pública, inscrita no marco dos direitos sociais.

Ao revisitar a trajetória da Assistência Social no Brasil, é possível identificar o paralelo estabelecido entre pobreza e violência, o qual atravessa distintas configurações da Política. O substrato da intervenção e o referencial de proteção assistencial no país foram forjados, dentre outros fatores, em contraponto à essa associação. Ainda que os termos e anunciados dos programas e projetos assistenciais não reportassem, necessariamente, a relação causal entre pobreza e violência, os arranjos formais da política ${ }^{35}$ incrustaram critérios de seleção dos riscos atribuídos às famílias em situação de pobreza - dentre eles, a reprodução de condutas e práticas violentas, para com os seus e a sociedade.

A normativas advindas do ciclo inaugurado pela PNAS/2004 estabeleceram parâmetros e níveis de atenção específicos, numa perspectiva de orientar o trânsito das ações e garantias socioassistenciais. O ordenamento institucional da Política, pautado pelo SUAS, materializou projeções progressistas, reivindicações históricas de segmentos e movimentos sociais ligados à área. No desenho vigente, o fenômeno da violência comparece como um dos elementos de transição entre as proteções, uma vez que sua ocorrência é identificada como expressão de violação de direitos, disposta no eixo de atribuições da PSE.

35 Conferir, no primeiro capítulo, a exposição sobre as primeiras instituições assistenciais na década de 1940, bem como o debate sobre o controle punitivo na interpretação das diretrizes contemporâneas da Política de Assistência Social, presente no Capítulo II. 
O movimento de investigação considerou, portanto, a relevância do marco normativo instituído pela PNAS/2004, sem o qual o próprio exercício crítico afeito à violência como campo de intervenção da Política se tornaria inócuo. Se a violência, sob a forma de suas manifestações no âmbito familiar e interpessoal, é tomada como justificativa para a intervenção da Assistência Social desde as protoformas assistenciais aos serviços tipificados atuais, o diferencial da análise se estabelece a partir da mediação entre as proposições institucionalizadas e a operacionalização cotidiana da Política. Em outras palavras, os pressupostos para a realização da pesquisa se tornaram viáveis em razão da materialidade e da estrutura normativa do SUAS.

\section{1.}

\section{O método da pesquisa}

O método da pesquisa, baseado na análise documental, objetivou analisar as concepções que qualificam o fenômeno da violência como campo de intervenção da Política de Assistência Social. Nestes termos, o acervo da PNAS/2004 se apresentou como fonte documental estratégica, considerando o registro - temático e temporal - das informações necessárias para a identificação dos princípios, diretrizes e estratégias de intervenção em disputa no campo socioassistencial da PSE de média complexidade, em especial no PAEFI. Pautadas nos pressupostos iniciais da pesquisa, tais dimensões forjam a apreensão do fenômeno da violência associado às famílias em situação de pobreza, bem como assentem com práticas coercitivas, escamoteadas pelo discurso da proteção social.

Em relação à aplicação dos métodos e teorias, importa destacar que, na pesquisa qualitativa, "o objeto em estudo é o fator determinante para a escolha de um método, e não o contrário" (FLICK, 2009). A elaboração do questionamento inicial, em outras palavras, da pergunta que orienta a pesquisa, ou a definição do problema, constituem um processo fundamental, posto que o método será definido a partir destas inferências. A definição pela análise documental partiu da delimitação do objeto, o qual problematiza as construções de sentido e significados que balizam a violência e, em consequência, determinam o escopo de intervenção e das proposições do acompanhamento familiar no PAEFI. 
Cellard (2008) adverte que a pesquisa documental exige, desde o início, um exercício sólido e criativo para o reconhecimento das fontes potenciais de informações, tendo em vista o objeto em estudo e o questionamento da pesquisa. Aconselha, ainda, que o investigador organize um inventário exaustivo e uma seleção rigorosa das informações disponíveis, etapas prévias ao exame das fontes selecionadas. Para o autor, um pesquisador que recorre à pesquisa documental deve, com a finalidade de " $(. .$.$) constituir um corpus satisfatório, esgotar todas as pistas$ capazes de lhe fornecer informações interessantes" (CELLARD, 2008, p. 298).

Ao retomar os arranjos da pesquisa, as recomendações citadas vêm à tona, em especial pelo acesso aos documentos governamentais, sujeito a restrições dos períodos eleitorais ou até mesmo às intempéries provocadas pela alternância dos gestores. A despeito dos avanços que as políticas de transparência representaram para a administração pública, os traços de descontinuidade e vinculação das políticas públicas como marcas de governos representam obstáculos para a recomposição histórica de documentos oficiais. Decerto, o acervo documental da Política de Assistência Social guarda resquícios destes entraves, o que determinou um movimento de antecipação no plano metodológico do estudo, tendo sido viável estruturar um acervo documental denso para a pesquisa.

O processo de investigação requisitou a análise dos documentos e normativas que dimensionam o histórico, a concepção, a execução, a avaliação e a formação continuada na PSE de média complexidade, enquanto diretivas institucionais que imprimem materialidade à proposta de acompanhamento familiar do CREAS. Para tanto, foram selecionados documentos ${ }^{36}$ centrais para a análise dos pressupostos da PSE de média complexidade e do PAEFI, destacados dentre as normativas, planos, orientações técnicas, instruções, portarias e cadernos publicados pelo Executivo Federal - responsável pela gestão da Política de Assistência de Social, em âmbito nacional.

A etapa inicial da pesquisa compreendeu a avaliação preliminar dos documentos escolhidos, passo que corresponde, segundo Sá-Silva et al (2009), à primeira etapa de qualquer análise documental. Cellard (2008) estabelece as cinco dimensões do processo inicial de investigação, a saber: contexto, autor ou autores,

36 Sistematizados no quadro intitulado - plano metodológico, apresentado na sequência do Capítulo. 
autenticidade e confiabilidade do texto, natureza, conceitos-chave e a lógica interna do texto. Ao assumir as dimensões, indicadas pelo autor, como pilares da pesquisa, foi possível estabelecer um plano metodológico de referência, no qual encontramse dispostas as indagações que orientaram a investigação.

A dimensão relativa ao contexto objetivou reconhecer a conjuntura e o tempo histórico dos documentos - qual o cenário que caracteriza a promulgação da PNAS/2004 e das normativas operacionais da PSE de média complexidade? E no que se refere aos autores, quem foram as representações governamentais, da sociedade civil e do meio acadêmico que orientaram a redação dos documentos da Política? Quanto à autenticidade e a confiabilidade do texto, fez-se necessário associar a natureza dos documentos às suas determinações, num exercício voltado para a identificação dos interesses que permearam uma dada direção de violência ao corpo normativo da PNAS/2004 e documentos normativos subsequentes.

E, finalmente, a identificação dos conceitos-chave e da própria lógica de argumentação permitiu a leitura detida aos sentidos mobilizados e, assim, a compreensão do aporte político que sustenta tais defesas semânticas - quais os sentidos e definições das categorias risco social, vulnerabilidade, violação de direitos, território, matricialidade sociofamiliar, proteção social, pobreza e violência na PNAS/2004 e orientações normativas posteriores? As perguntas formuladas perseguem o encadeamento entre a problemática da pesquisa e as observações extraídas da documentação, dinâmica que, nas palavras de Cellard, “(...) viabilizam a formulação de explicações plausíveis, a produção de uma interpretação coerente e a reconstrução de um aspecto qualquer de uma dada sociedade, neste ou naquele momento" (2008, p. 304).

A etapa subsequente abarcou a análise dos documentos, desenvolvida a partir da discussão da temática e os elementos reunidos na fase inicial da investigação, à luz das referências bibliográficas e do quadro teórico que orientou a pesquisa. Segundo a perspectiva de Cellard (2008), em tal fase, o pesquisador reúne as dimensões problematizadas, com o intuito de subsidiar uma interpretação plausível, tendo em vista a temática ou a pergunta que orientou a pesquisa. A análise do conteúdo foi conduzida pela metodologia qualitativa, recurso que permitiu identificar a coexistência do discurso protetivo com elementos que remetem ao controle punitivo das famílias, em especial dos núcleos em situação de pobreza. 
De acordo com Sá-Silva (2009), a análise do conteúdo consiste em relacionar a frequência da citação de alguns temas, palavras ou ideias em um texto para medir o peso relativo atribuído a um determinado assunto. Nos documentos submetidos ao estudo, importou reconhecer as defesas estabelecidas no decurso da implantação da PNAS/2004 e, assim, as interpretações e categorias afeitas ao fenômeno da violência, a depender do tipo da publicação e público para o qual se destina.

\begin{abstract}
A análise qualitativa do conteúdo começa com a ideia de processo, ou contexto social, e vê o autor como um autoconsciente que se dirige a um público em circunstâncias particulares. A tarefa do analista torna-se uma leitura do texto em termos dos seus símbolos. Com isso em mente, o texto é abordado a partir do entendimento do contexto da sua produção pelos próprios analistas. Devemos então estar atentos para o fato de que a análise de conteúdo pode caracterizar-se como um método de investigação do conteúdo simbólico das mensagens. Essas mensagens podem ser abordadas de diferentes formas e sob inúmeros ângulos. (SÁ-SILVA, 2009, p. 11).
\end{abstract}

Com base na bibliografia explorada (SÁ-SILVA, 2009; LUDKE e ANDRÉ, 1986), é possível afirmar que o processo de análise de conteúdo dos documentos tem início quando se define a unidade de análise, dividida entre unidade de registro e unidade de contexto. Por efeito do recorte do objeto, a pesquisa perseguiu a unidade do contexto, considerando explorar as correlações que definiram as categorias que particularizam a PSE de média complexidade e o PAEFI, as garantias socioassistenciais previstas como medidas de reparação de direitos e as expressões de violência incorporadas às fontes de registros de atendimento do SUAS.

O movimento de investigação foi orientado pelo questionamento acerca da concepção de violência que orienta e conforma a PSE de média complexidade, em particular o PAEFI, com o intuito de apreender o sentido das intervenções voltadas para as famílias pobres, a partir da expectativa depositada nas garantias de reparação, como no formato dos registros oficiais das intervenções da PSE. Tratase de um movimento de confronto entre a orientação teórica e os extratos de realidade sob análise, que encaminha, segundo Shiroma et al (2005), a compreensão dos argumentos privilegiados e aqueles que são intencionalmente desprezados. E, assim, oferecer elementos de análise que se aproximem da lógica ou racionalidade que embasam os documentos, “(...) tarefa que exige um olhar investigativo sobre 
os textos oficiais - legislação, relatório, documento - para ler o que dizem, mas também para captar o que não dizem" (SHIROMA et al, 2005, p. 439).

\section{2.}

\section{O percurso metodológico da pesquisa}

A pesquisa objetivou analisar as concepções que qualificam o fenômeno da violência na Política de Assistência Social, a partir do estudo das normativas que, a partir da implementação da PNAS/2004, institucionalizaram o campo de atuação da PSE de média complexidade. O movimento de análise almejou identificar as categorias que delimitam o campo de intervenção do serviço de acompanhamento familiar do CREAS - o PAEFI, de modo a interpretar o recorte de violência que passou a ser formalmente atribuído à Assistência Social na atualidade.

A partir desse panorama, a investigação examinou as garantias socioassistenciais previstas como medidas de reparação de direitos no acompanhamento familiar da PSE de média complexidade, considerando que a premissa para o acompanhamento do PAEFI envolve as situações de risco social e pessoal, por violação de direitos. E a violência, nesse contexto, é reconhecida, nas produções recentes da Política, como uma das formas mais severas da violação de direitos (BRASIL, 2018a). Não obstante, a interpretação do fenômeno (e suas manifestações intrafamiliares e interpessoais) não figurou dentre as categorias privilegiadas pela Política nas duas últimas décadas, ausência que, decerto, agregou elementos para a interpretação do vocabulário socioassistencial adotado no período em estudo.

Em complemento, a pesquisa se voltou para a análise das expressões de violência incorporadas aos registros de atendimento e aos instrumentos de avaliação oficiais do SUAS, de modo a reconhecer os marcadores de violência que orientam a produção e a análise de dados da PSE de média complexidade, em especial do PAEFI. Trata-se de reconhecer o privilégio que a temática assume nos documentos afeitos à avaliação e monitoramento da Política - tendência que remonta impressões iniciais da investigação, as quais apontam que a abordagem à violência se detém à mera citação, nos documentos relacionados à concepção e implementação das 
Proteções, enquanto que as normativas detidas à operacionalização dos serviços esboçam um movimento de descrição, com aporte, inclusive, de referenciais teóricos sobre a violência.

Diante da formulação dos objetivos, geral e específicos do estudo, além da pergunta decisiva para a definição do método da pesquisa, a análise se voltou para a seleção dos documentos reconhecidos como fontes potenciais de informações no acerco documental da PNAS/2004.Com efeito, foram realizadas pesquisas no sítio eletrônico do Executivo Federal, responsável pela gestão nacional da Política, estrutura que, no decorrer de duas décadas, contou com distintas nomenclaturas, a saber: Ministério do Desenvolvimento Social e Combate à Fome (MDS), durante os governos de Luiz Inácio Lula da Silva e Dilma Rousseff; e, Ministério do Desenvolvimento Social (MDS), no decorrer da administração de Michel Temer ${ }^{37}$.

O período do estudo demarcaria, inicialmente, a efetivação da Política Nacional, em 2004, contemplando as resoluções e normativas publicadas até o ano de 2018. As justificativas para o arco temporal da pesquisa compreendiam, como principais motivações, a representatividade da PNAS, a consolidação do SUAS e a expressiva cobertura da rede socioassistencial, em âmbito nacional, no decurso de 2004 a 2018. No entanto, no transcorrer do trabalho de campo, fez-se necessário incorporar o documento do Programa de Combate ao Abuso e à Exploração Sexual de Crianças e Adolescentes, também conhecido como Sentinela, o qual data do ano de 2001, tendo em vista a imperiosa contextualização dos antecedentes institucionais do PAEFI.

Ainda no que tange ao período da pesquisa, cabe explicitar as razões que orientaram a seleção de documentos publicados até o ano limite de 2018. A decisão por não contemplar as produções advindas do governo de Jair Messias Bolsonaro, autoridade com mandato presidencial em curso, envolveu distintas questões, com destaque para: a linha de corte em 2018 no projeto de pesquisa submetido à admissão na linha de pesquisa do Programa de Pós-Graduação em Serviço Social, produção que já incorporava elementos de análise capitais para o curso da pesquisa; bem como, as abruptas modificações no ordenamento institucional da Política de 2016; e, Michel Temer - 31 de agosto de 2016 a 31 de dezembro de 2018. 
Assistência Social, em que pese a perda do status ministerial das políticas de Desenvolvimento Social, a partir da fusão com as pastas do Esporte e da Cultura, agora denominado Ministério da Cidadania.

No tocante ao último, além das perdas atribuídas ao lugar institucional da Política na estrutura decisória do Executivo Federal, ressalta-se, ainda, a relevância de um investimento analítico na abordagem da violência, por parte da Assistência Social, prévio ao governo de Jair Bolsonaro. Em outras palavras, a administração atual ao legitimar o avanço de pautas assistenciais conservadoras, como o investimento no Programa Criança Feliz ${ }^{38}$, destinado a potencializar competências e estimular a responsabilização dos adultos, amplia questões de análise da Política, que, decerto, extrapolam o recorte detido ao fenômeno da violência. O estudo reconhece, como sublinhado na apresentação da dissertação, que as expressões de violência, detidas às expressões manifestas nas relações familiares e interpessoais, não foram suficientemente exploradas por parte das produções dedicadas à análise da PSE de média complexidade e do PAEFI.

Com a definição do período, o próximo passo envolveu a triagem inicial dos documentos, selecionados a partir de pesquisa online no banco de legislações e publicações da Rede $\operatorname{SUAS}^{39}$. A ferramenta de busca permite a aplicação de filtros específicos de pesquisa, como a busca por ano, o tipo de publicação ${ }^{40}$ e por palavras chave. Desse modo, a estratégia inicial sistematizou os documentos orientadores da Política, dispostos pela linha do tempo, bem como pela seleção induzida das seguintes expressões: média complexidade; violação de direitos; violência; CREAS e PAEFI.

Sendo assim, o exame inicial se debruçou em trinta e dois documentos, dispostos por ano de publicação, pelo tipo do documento e pela vinculação à PSE

38 Cabe sublinhar, dentre tantas medidas regressivas, o Programa Criança Feliz, iniciado na administração de Michel Temer, o qual se apresenta como suporte às famílias pobres e em extrema pobreza, para que as mesmas exerçam suas funções de proteção, cuidado e educação das crianças na primeira infância, com o discurso de potencializar suas competências e estimular à responsabilização dos adultos de referência nos núcleos familiares (BRASIL, 2017). Ou seja, reatualiza “(...) o foco em apoiar as famílias para que elas deem conta da proteção de seus membros, no sentido de responsabilização, sobrecarregando seu papel, para desonerar o Estado, o que remonta a práticas higienistas de controle sobre o núcleo familiar" (EMANOEL, 2018, p. 876).

39 Disponível em: http://aplicacoes.mds.gov.br/snas/regulacao/atos_normativos.php

40 Como leis, decretos, resoluções, atos normativos, portarias, recomendações, manuais técnicos, dentre outros. 
e, em particular, à PSE de média complexidade ${ }^{41}$. A avaliação das publicações permitiu a identificação e posterior desagregação dos documentos em quatro grupos de análise, com a aplicação do critério de classificação inspirado no ciclo das políticas públicas (SOUZA, 2006), então denominados: formulação, implementação, monitoramento/avaliação e capacitação.

A referência das fases do ciclo das políticas públicas contribuiu para a distinção dos documentos a partir de elementos característicos, tomados num contexto de formulação cíclica, a considerar o período estipulado para a pesquisa. Nesse contexto de aproximação com o ciclo da Assistência Social, centrado na PSE de média complexidade e no PAEFI, cabe esclarecer quais pressupostos foram considerados para reunir os documentos em torno das fases, considerando que as produções da Política não reproduzem tais tipificações. Trata-se, portanto, de um exercício de categorização próprio da pesquisa, orientado pelos referenciais teóricos e premissas da investigação - princípios norteadores que orientaram o processo de produção e análise de dados subsequentes.

Em linhas gerais, a formulação de políticas públicas constitui-se “(...) no estágio em que os governos democráticos traduzem seus propósitos e plataformas eleitorais em programas e ações que produzirão resultados ou mudanças no mundo real" (SOUZA, 2006, p. 26). Posterior à formação da agenda, momento em que decorre o planejamento das questões prioritárias para o poder público, o tópico da formulação envolve a definição dos objetivos da Política, os programas desenvolvidos e as linhas de ação priorizadas.

No que se refere à implementação, é o estágio em que o planejamento e a pauta política são transformados em ações. Envolve a operacionalização do que fora firmado no plano dos desígnios da Política, a execução do que se sustentou como pauta na esfera do planejamento. Para tanto, contempla o direcionamento de recursos financeiros, tecnológicos, materiais e humanos para materializar os programas, projetos e linhas de ação da política pública ${ }^{42}$.

O eixo do monitoramento e avaliação corresponde ao processo de revisão contínuo do ciclo da Política, desde a formação da agenda até a análise das

41 Conferir anexo I.

42 Ciclo das Política Públicas, acesso em 19/03/2020: https://www.politize.com.br/ciclo-politicaspublicas/. 
mudanças sociais decorrentes delas. Compreende a análise dos efeitos produzidos na sociedade pelas políticas públicas, bem como mensuração desses efeitos, de modo a induzir alterações no decurso da implementação ou, até mesmo, retornar à instância inicial de formação da agenda da Política (SOUZA, 2006).

Diante do exposto, a pesquisa avançou para a organização dos documentos em acordo com as fases do ciclo das políticas públicas, exercício que observou a natureza da normativa, as definições dos instrumentais, objetivos do documento, público para o qual se destina e data da publicação. Importa ressalvar, entretanto, a inclusão do termo capacitação/formação continuada dentre os eixos do ciclo de análise da Política de Assistência, uma vez que tal expressão não se aplica às fases descritas nas bibliografias utilizadas.

É possível ponderar que o documento vinculado ao tópico da formação continuada $^{43}$ seja interpretado como uma normativa da implementação, considerando se tratar de recomendações e instruções para o refinamento da execução dos serviços socioassistenciais. Contudo, a publicação se propõe a discutir aspectos inéditos e de suma relevância para abordagem e debate da violência no campo da Assistência Social, nuances que influenciaram sua posição destacada dos documentos que versam sobre a operacionalização da PSE de média complexidade e do PAEFI. Em tempo, como argumento de defesa, acresce-se, ainda, que a publicação fora lançada em 2018, o que a define como última normativa analisada na pesquisa.

A etapa imediata contemplou a seleção dos documentos por fase do ciclo da Política, momento fundamental para o mapeamento das produções de destaque, a depender da relevância para a etapa do processo, bem como as contribuições para as questões formuladas no roteiro de análise. Neste ponto, cabe ressalvar que a pauta das perguntas foi elaborada a partir dos objetivos da pesquisa. Entretanto, as indagações sofreram adaptações, considerando a especificidade do documento em análise. Num breve exercício de ilustração, vale ressalvar que a indagação referente à definição do PAEFI não se aplica, por exemplo, à PNAS/2004, uma vez que o serviço de acompanhamento especializado assume tal nomenclatura a partir de 2009, com a Tipificação Nacional dos Serviços Socioassistenciais. Nesse contexto,

43 Documento: Curso Proteção social no SUAS a indivíduos e famílias em situação de violência e outras violações de direitos: Fortalecimento da Rede Socioassistencial. 
a abordagem à PNAS/2004 se voltou para a análise do Serviço de Orientação e Apoio Sociofamiliar, que foi anunciado como modelo do acompanhamento familiar e individual no CREAS, formato que antecedeu o PAEFI.

A partir da exposição dos critérios para a organização e seleção das normativas, o quadro metodológico abaixo reúne as produções analisadas como fontes documentais, dispostas por título e ano da publicação, autoria e síntese das proposições, a conferir:

Quadro 1 - Relação dos documentos analisados

\begin{tabular}{|c|c|c|c|}
\hline \multicolumn{4}{|c|}{ Quadro Metodológico } \\
\hline Título & Ano & Órgão Responsável & Síntese das Proposições \\
\hline $\begin{array}{c}\text { Portaria } \mathrm{n}^{\circ} \\
878, \text { de } 03 \text { de } \\
\text { dezembro de } \\
2001\end{array}$ & 2001 & $\begin{array}{c}\text { Ministério da } \\
\text { Previdência e Assistência } \\
\text { Social Secretaria de } \\
\text { Estado de Assistência } \\
\text { Social }\end{array}$ & $\begin{array}{l}\text { Estabelece Diretrizes e Normas do } \\
\text { Programa Sentinela, com vistas à } \\
\text { regulamentação da sua } \\
\text { implementação e operacionalização. }\end{array}$ \\
\hline $\begin{array}{l}\text { Política } \\
\text { Nacional de } \\
\text { Assistência } \\
\text { Social - } \\
\text { PNAS }\end{array}$ & 2004 & $\begin{array}{c}\text { Ministério do } \\
\text { Desenvolvimento Social } \\
\text { e Combate à Fome, } \\
\text { Secretaria Nacional de } \\
\text { Assistência Social e } \\
\text { Conselho Nacional de } \\
\text { Assistência Social }\end{array}$ & $\begin{array}{l}\text { Redesenho da Política de Assistência } \\
\text { Social, na perspectiva de } \\
\text { implementação do SUAS. }\end{array}$ \\
\hline $\begin{array}{l}\text { Norma } \\
\text { Operacional } \\
\text { Básica - } \\
\text { NOB/SUAS }\end{array}$ & 2005 & $\begin{array}{c}\text { Ministério do } \\
\text { Desenvolvimento Social } \\
\text { e Combate à Fome e } \\
\text { Secretaria Nacional de } \\
\text { Assistência Social e } \\
\text { Conselho Nacional de } \\
\text { Assistência Social }\end{array}$ & $\begin{array}{l}\text { NOB/SUAS consagra os eixos } \\
\text { estruturantes para a realização do } \\
\text { pacto entre os entes federados, } \\
\text { visando a consolidação do SUAS no } \\
\text { Brasil. Disciplina a gestão pública da } \\
\text { Política de AS. }\end{array}$ \\
\hline $\begin{array}{c}\text { Guia de } \\
\text { Orientação do } \\
\text { CREAS - } 1^{\mathrm{a}} \\
\text { Versão }\end{array}$ & 2006 & $\begin{array}{c}\text { Ministério do } \\
\text { Desenvolvimento Social } \\
\text { e Combate à Fome e } \\
\text { Secretaria Nacional de } \\
\text { Assistência Social }\end{array}$ & $\begin{array}{l}\text { Detalha aspectos relacionados à } \\
\text { caracterização do CREAS; sua } \\
\text { organização e gestão; o } \\
\text { cofinanciamento do MDS; os } \\
\text { serviços oferecidos; as instalações } \\
\text { físicas; composição, formação e } \\
\text { capacitação da equipe que atua nos } \\
\text { serviços elencados; e o } \\
\text { monitoramento e a avaliação dos } \\
\text { processos de trabalho implementados. }\end{array}$ \\
\hline
\end{tabular}




\begin{tabular}{|c|c|c|c|}
\hline \multicolumn{3}{|c|}{ Quadro Metodológico } \\
\hline Título & Ano & $\begin{array}{c}\text { Órgão } \\
\text { Responsável }\end{array}$ & Síntese das Proposições \\
\hline $\begin{array}{c}\text { Tipificação Nacional } \\
\text { dos Serviços } \\
\text { Socioassistenciais }\end{array}$ & 2009 & $\begin{array}{c}\text { Secretaria } \\
\text { Nacional de } \\
\text { Assistência Social } \\
\text { e Conselho } \\
\text { Nacional de } \\
\text { Assistência Social }\end{array}$ & $\begin{array}{c}\text { Padronização em todo território } \\
\text { nacional dos serviços de proteção } \\
\text { social básica especial, } \\
\text { estabelecendo seus conteúdos } \\
\text { essenciais, público a ser atendido, } \\
\text { propósito de cada um deles e os } \\
\text { resultados esperados para a garantia } \\
\text { dos direitos socioassistenciais }\end{array}$ \\
\hline $\begin{array}{c}\text { Lei Orgânica da } \\
\text { Assistência Social (Lei } \\
\text { do SUAS) }\end{array}$ & 2011 & $\begin{array}{c}\text { Lei Federal no } \\
12.435, \text { de 6 de } \\
\text { julho de 2011. }\end{array}$ & $\begin{array}{c}\text { Altera a Lei no } 8.742 \text {, de 7 de } \\
\text { dezembro de 1993, que dispõe sobre } \\
\text { arganização da Assistência Social. } \\
\text { Institucionaliza o SUAS. }\end{array}$ \\
\hline $\begin{array}{c}\text { Orientações Técnicas: } \\
\text { Centro de Referência } \\
\text { Especializado de } \\
\text { Assistência Social }\end{array}$ & 2011 & $\begin{array}{c}\text { Secretaria } \\
\text { Nacional de } \\
\text { Assistência Social }\end{array}$ & $\begin{array}{c}\text { O documento "Orientações } \\
\text { Técnicas: Centro de Referência } \\
\text { Especializado de Assistência Social } \\
\text { CREAS)" reúne informações para } \\
\text { subsidiar a implantação, } \\
\text { organização, funcionamento e } \\
\text { aprimoramento dos CREAS no país. }\end{array}$ \\
\hline
\end{tabular}




\begin{tabular}{|c|c|c|c|}
\hline \multicolumn{4}{|c|}{ Quadro Metodológico } \\
\hline Título & Ano & Órgão Responsável & Síntese das Proposições \\
\hline $\begin{array}{c}\text { Resolução } \\
\text { acerca dos } \\
\text { Parâmetros } \\
\text { Nacionais } \\
\text { para o } \\
\text { Registro de } \\
\text { Informações } \\
\text { relativas aos } \\
\text { serviços dos } \\
\text { CRAS, } \\
\text { CREAS e } \\
\text { Centro } \\
\text { POP. }\end{array}$ & $\begin{array}{c}2011 \\
\text { (Incorpora } \\
\text { as } \\
\text { Atualizações } \\
\text { de 2013 e } \\
\text { 2017). }\end{array}$ & $\begin{array}{l}\text { Secretaria Nacional de } \\
\text { Assistência Social e } \\
\text { Comissão Intergestores } \\
\text { Tripartite }\end{array}$ & $\begin{array}{l}\text { Institui parâmetros nacionais para } \\
\text { o registro das informações } \\
\text { relativas aos serviços ofertados } \\
\text { nos Centros de Referência da } \\
\text { Assistência Social - CRAS, nos } \\
\text { Centros de Referência } \\
\text { Especializados da Assistência } \\
\text { Social - CREAS, e nos Centros de } \\
\text { Referência Especializados para } \\
\text { População em Situação de Rua - } \\
\text { Centro Pop e define o conjunto de } \\
\text { informações que devem ser } \\
\text { coletadas, organizadas e } \\
\text { armazenadas pelas referidas } \\
\text { unidades, em todo o território } \\
\text { nacional. }\end{array}$ \\
\hline NOB SUAS & 2012 & $\begin{array}{c}\text { Ministério do } \\
\text { Desenvolvimento } \\
\text { Social e Combate à } \\
\text { Fome, Secretaria } \\
\text { Nacional de } \\
\text { Assistência Social e } \\
\text { Conselho Nacional de } \\
\text { Assistência Social }\end{array}$ & $\begin{array}{c}\text { O caráter desta norma } \\
\text { operacional diz respeito a um } \\
\text { novo patamar necessário para o } \\
\text { aprimoramento do SUAS, por } \\
\text { meio da introdução de novas } \\
\text { estratégias de financiamento e } \\
\text { gestão, consubstanciadas na } \\
\text { instituição dos blocos de } \\
\text { financiamento, na pactuação de } \\
\text { prioridades e metas, valorização } \\
\text { da informação, do monitoramento } \\
\text { e do planejamento como } \\
\text { ferramentas de gestão e na } \\
\text { instituição de um novo regime de } \\
\text { colaboração entre os entes, por } \\
\text { meio do apoio técnico e } \\
\text { financeiro, orientado por } \\
\text { prioridades e para o alcance das } \\
\text { metas de aprimoramento do } \\
\text { sistema. }\end{array}$ \\
\hline
\end{tabular}




\begin{tabular}{|c|c|c|c|}
\hline \multicolumn{4}{|c|}{ Quadro Metodológico } \\
\hline Título & Ano & $\begin{array}{c}\text { Órgão } \\
\text { Responsável }\end{array}$ & Síntese das Proposições \\
\hline $\begin{array}{l}\text { Manual de } \\
\text { Instruções para } \\
\text { o Registro } \\
\text { Mensal de } \\
\text { Atendimentos } \\
\text { do CREAS }\end{array}$ & $\begin{array}{c}2014 \\
\text { (Atualizações } \\
\text { em 2018) }\end{array}$ & $\begin{array}{l}\text { Secretaria } \\
\text { Nacional de } \\
\text { Assistência } \\
\text { Social }\end{array}$ & $\begin{array}{l}\text { Este Manual de Instruções tem } \\
\text { como objetivo auxiliar os técnicos } \\
\text { e gestores do SUAS no } \\
\text { preenchimento do Registro Mensal } \\
\text { de Atendimentos (RMA) do } \\
\text { CREAS. }\end{array}$ \\
\hline $\begin{array}{l}\text { Manual } \\
\text { Prontuário } \\
\text { SUAS }\end{array}$ & 2014 & $\begin{array}{c}\text { Ministério do } \\
\text { Desenvolvimento } \\
\text { Social e Combate } \\
\text { à Fome, } \\
\text { Secretaria } \\
\text { Nacional de } \\
\text { Assistência } \\
\text { Social e } \\
\text { Fundação } \\
\text { Oswaldo Cruz } \\
\text { (FIOCRUZ) }\end{array}$ & $\begin{array}{l}\text { O Prontuário SUAS foi elaborado } \\
\text { com a intenção de ofertar as } \\
\text { equipes técnicas dos CRAS e } \\
\text { CREAS um instrumento nacional } \\
\text { padronizado para registro das } \\
\text { informações resultantes da } \\
\text { dinâmica do trabalho social com as } \\
\text { famílias, especialmente aquele } \\
\text { realizado no âmbito do PAIF e do } \\
\text { PAEFI. }\end{array}$ \\
\hline $\begin{array}{c}\text { Nota Técnica } \\
\text { SUAS e Sistema } \\
\text { de Justiça }\end{array}$ & 2016 & $\begin{array}{c}\text { Secretaria } \\
\text { Nacional de } \\
\text { Assistência } \\
\text { Social }\end{array}$ & $\begin{array}{l}\text { Documento descreve a natureza do } \\
\text { trabalho social desenvolvido pelos } \\
\text { profissionais das equipes de } \\
\text { referência no âmbito do Sistema } \\
\text { Único de Assistência Social- } \\
\text { SUAS, de modo a reconhecer e } \\
\text { afirmar seu escopo de atuar e } \\
\text { subsidiar o diálogo na relação } \\
\text { interinstitucional, presente nos } \\
\text { territórios, com os órgãos do } \\
\text { Sistema de Justiça, tais como } \\
\text { Poder Judiciário, Ministério } \\
\text { Público e Defensoria Pública. }\end{array}$ \\
\hline $\begin{array}{l}\text { Curso Proteção } \\
\text { social no SUAS } \\
\text { a indivíduos e } \\
\text { famílias em } \\
\text { situação de } \\
\text { violência e } \\
\text { outras violações } \\
\text { de direitos: } \\
\text { fortalecimento } \\
\text { da rede } \\
\text { socioassistencial }\end{array}$ & 2018 & $\begin{array}{c}\text { Ministério do } \\
\text { Desenvolvimento } \\
\text { Social Secretaria } \\
\text { Nacional de } \\
\text { Assistência } \\
\text { Social e } \\
\text { Fundação } \\
\text { Oswaldo Cruz } \\
\text { (FIOCRUZ) }\end{array}$ & $\begin{array}{c}\text { Subsidia o curso "Proteção social } \\
\text { no SUAS a indivíduos e famílias } \\
\text { em situação de violência e outras } \\
\text { violações de direito: fortalecimento } \\
\text { da rede socioassistencial". } \\
\text { Produções que representam os } \\
\text { esforços em direção ao } \\
\text { aprimoramento do cuidado e da } \\
\text { atenção que os equipamentos, } \\
\text { serviços e equipes de trabalho do } \\
\text { SUAS dispensam no } \\
\text { enfrentamento da problemática da } \\
\text { violência e outras violações de } \\
\text { direito. }\end{array}$ \\
\hline
\end{tabular}

Ao expor os documentos selecionados como principais fontes de informações, cabe a apresentação das normativas por fase do ciclo de análise da 
Política de Assistência Social, com o adendo quanto à inclusão do tópico capacitação/formação continuada ao fluxograma de processo.

Quadro 2 - Fluxograma dos documentos analisados

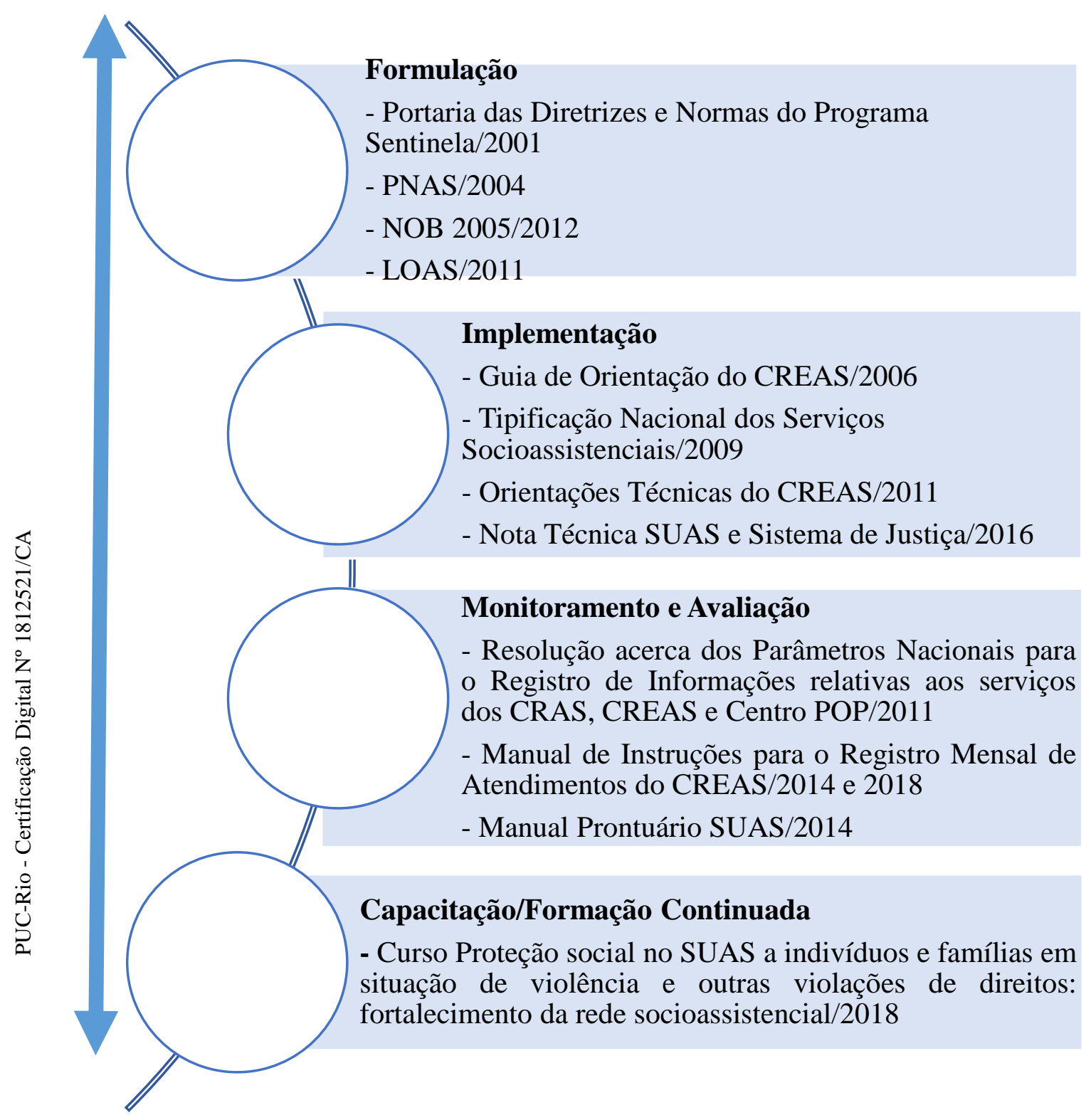

Por fim, o último quadro detalha o roteiro que norteou a aplicação das perguntas aos documentos, tendo em vista a necessária adaptação das indagações, a depender do tipo e classificação da normativa no ciclo de análise da Política de Assistência Social. O plano das perguntas orientou, em consequência, os tópicos da análise dos dados, abordados na sequência do Capítulo. 
Quadro 3 - Roteiro da pesquisa

\begin{tabular}{|c|c|}
\hline \multicolumn{2}{|r|}{ Roteiro } \\
\hline Objetivos & Perguntas \\
\hline $\begin{array}{l}\text { Analisar as } \\
\text { concepções que } \\
\text { qualificam o } \\
\text { fenômeno da violência } \\
\text { na Política Nacional } \\
\text { de Assistência Social. }\end{array}$ & $\begin{array}{l}\text { 1) O documento apresenta alguma definição de } \\
\text { violência? Caso sim, qual (s)? }\end{array}$ \\
\hline $\begin{array}{l}\text { Identificar as } \\
\text { categorias que } \\
\text { delimitam o campo de } \\
\text { intervenção dos } \\
\text { serviços } \\
\text { socioassistenciais } \\
\text { atrelados à PSE de } \\
\text { média complexidade. }\end{array}$ & $\begin{array}{l}\text { 2)Como o documento relaciona a diretriz da } \\
\text { matricialidade familiar e a violação de direitos na PSE? } \\
\text { 3) Qual a definição da PSE de média complexidade / } \\
\text { PAEFI? } \\
\text { 4) O documento estipula as expressões de violência } \\
\text { pertinentes à PSE de média complexidade / PAEFI? } \\
\text { 5) Ouais as prerrogativas do acompanhamento familiar }\end{array}$ \\
\hline $\begin{array}{l}\text { Examinar as garantias } \\
\text { socioassistenciais } \\
\text { previstas como } \\
\text { medidas de reparação } \\
\text { de direitos na PSE de } \\
\text { média complexidade. }\end{array}$ & $\begin{array}{l}\text { ofertado na PSE de média complexidade / PAEFI? } \\
\text { 6) Como o documento prevê a articulação com o } \\
\text { Sistema de Justiça na dinâmica da PSE? } \\
\text { 7) Quais as medidas de reparação de direitos previstas }\end{array}$ \\
\hline $\begin{array}{l}\text { Distinguir as } \\
\text { expressões de } \\
\text { violência incorporadas } \\
\text { aos registros de } \\
\text { atendimento oficiais } \\
\text { no SUAS. }\end{array}$ & $\begin{array}{l}\text { no acompanhamento da PSE de média complexidade? } \\
\text { 8) Quais marcadores de violência o documento propõe } \\
\text { para sistematizar a produção de dados da PSE? }\end{array}$ \\
\hline
\end{tabular}

\section{3.}

\section{Sistematização dos dados qualitativos - a transição temporal da abordagem ao fenômeno da violência nas publicações.}

O presente tópico contempla a análise sobre as concepções que qualificam o fenômeno da violência como campo de intervenção da Assistência Social, considerando o desenho normativo e prerrogativas da atenção socioassistencial delegadas ao serviço de acompanhamento familiar e individual da PSE de média 
complexidade. O estudo, detido aos recortes do fenômeno da violência que orientam o leque de garantias e medidas de reparação creditadas ao PAEFI, produziu dados a partir da análise dos documentos do ciclo de formulação, implementação e avaliação da Política, no período de 2001 a 2018.

Nesse contexto, a exposição dos resultados observou as fases do ciclo da Política de Assistência Social, com o intuito de demarcar a análise da violência nos documentos pertencentes ao mesmo escopo normativo - aqui definidos como: formulação, implementação, avaliação e formação continuada/capacitação. Portanto, a sistematização dos dados qualitativos considerou a transição temporal da abordagem ao fenômeno da violência nas publicações, processo que guarda particularidades, a depender da finalidade do documento, público ao qual se destina e do próprio processo de maturação política do SUAS no decorrer dos dois últimos decênios.

\subsection{1.}

\section{A violência nos documentos de formulação: do Programa Sentinela ao PAEFI.}

Os documentos vinculados à fase da formulação remetem, como mencionado, ao processo de institucionalização da Política de Assistência Social. As publicações definem os parâmetros nacionais dos serviços, programas e projetos, além de dispor sobre as coberturas, públicos específicos da atenção socioassistencial, padrão de financiamento, dentre outros elementos estratégicos do processo de gestão pública. As normativas deste eixo consolidam referenciais para a execução, ao estipular os objetivos e as linhas de ação que orientam o percurso da implementação, além dos marcos de revisão e avaliação das medidas propostas.

A análise do processo de concepção da Assistência Social, com ênfase na abordagem da violência como campo de intervenção da Política, envolveu a Portaria das Diretrizes e Normas do Programa Sentinela, a PNAS/2004, as Normas Operacionais Básicas publicadas em 2005 e 2012 e a Lei Orgânica da Assistência Social (LOAS), com as respectivas alterações aprovadas em 2011. Cabe ressalvar que a publicação referente ao Programa Sentinela compreende o ciclo de formulação da Política Nacional de Assistência Social de 1998, antecedente 
institucional relevante da PNAS/2004, ainda que, recorrentemente, negligenciado na recomposição histórica da Assistência Social contemporânea ${ }^{44}$.

Trata-se, portanto, da única normativa que não integra o ciclo da PNAS/2004, dentre as 14 publicações selecionadas para o estudo. A justificativa para a sua inclusão remonta ao trabalho de campo, mais precisamente, no decorrer da avaliação dos documentos que orientam a implementação do CREAS. Ao analisar as recomendações do serviço de acompanhamento da PSE de média complexidade, em especial as ressalvas e limites no trato cotidiano com as instituições do Sistema de Justiça ${ }^{45}$, fez-se necessário revisitar as versões institucionais que precederam o PAEFI, de modo a particularizar as expectativas que a Assistência Social já havia firmado nas intervenções junto às famílias e indivíduos em situação de violência, e que, atualmente, representam severos impasses para o acompanhamento autônomo por parte das equipes dos CREAS, além dos rebatimentos punitivos direcionados às famílias em situação de violência intrafamiliar.

Com efeito, a abordagem à normativa do Programa Sentinela observou a compreensão e o recorte de violência que definia a atuação da Assistência Social, além das garantias previstas no cardápio de ações legitimadas pela Política. O encadeamento temporal dos documentos de formulação, 2001 a 2012, permitiu a recomposição do histórico da violência como campo de intervenção socioassistencial, que abarcou desde a atenção específica a crianças e adolescentes vítimas de violência, com ênfase no abuso e exploração sexual (BRASIL, 2001), ao acompanhamento às famílias e indivíduos em situação de risco social e pessoal, por ocorrência de abandono, maus tratos físicos e, ou, psíquicos, abuso sexual, uso de substâncias psicoativas, cumprimento de medidas socioeducativas, situação de rua, situação de trabalho infantil (BRASIL, 2004), para a definição corrente do acompanhamento especializado às famílias e indivíduos em situação de risco pessoal ou social, por violação de direitos ou contingência (BRASIL, 2011).

44 De acordo com Alchorne, "Em 1998, ainda que pouco conhecida e debatida, é instituída a primeira versão oficial da Política Nacional de Assistência Social, através da Resolução no 207. Percebo que na maioria dos estudos precedentes ao tema há um salto no tempo. Em geral, sugerem como cronologia: Constituição Federal de 1988, LOAS/93, PNAS/2004 (SUAS) e deixam de lado a PNAS/98 e suas ideias". (2013, p.34)

45 Análises aprofundadas no tópico referente aos documentos da implementação. 
É possível reconhecer um movimento de alternância entre as normativas, que transita entre a definição da atuação por segmento e recorte específico de violência, considerando o detalhamento do Programa Sentinela, voltado para crianças e adolescentes vítimas de violência sexual, sob as formas de abuso e/ou exploração e a intervenção generalista no que se refere à violência no contexto da PNAS/2004, a qual assume a designação dos riscos, pessoal e social, por ocorrência de situações diversas, que abrangem expressões de violência, sem, no entanto, fazer menção ao fenômeno.

Nas definições dos documentos posteriores, os quais incorporam as modificações advindas do campo da operacionalização da Política ${ }^{46}$, é possível observar o investimento na aproximação com expressões de violência, ainda que se preserve a tendência de generalização proposta pela PNAS/2004. Sendo assim, a LOAS e a NOB/2012 incorporam a perspectiva da situação de risco pessoal e social, por violação de direitos - que, tal como problematizado no Capítulo II, encontra no fenômeno da violência uma das expressões mais severas das violações de Direitos Humanos.

Ao considerar o destaque, ou, o ocultamento, da violência nas normativas atreladas à concepção da Política, a análise se debruçou no desenho institucional dos serviços por segmentos e, posteriormente, às famílias e indivíduos em situação de violência e pobreza - definidos como público da Assistência Social, no eixo da PSE. Na Portaria do Sentinela, o Programa é detalhado a partir da articulação com os demais serviços da rede de políticas voltadas para a garantia de direitos de crianças e adolescentes, sendo responsável por assegurar "o acesso aos serviços de assistência social, saúde, educação, justiça e segurança, esporte, lazer e cultura, guardando compromisso ético, político e a multidisciplinariedade das ações". (BRASIL, 2001, p. 2).

Como prerrogativa da Assistência Social, o Sentinela destacou o atendimento, mediado por um conjunto articulado de ações, de crianças e adolescentes vitimados pela violência, com ênfase no abuso e exploração sexual (BRASIL, 2001). Pressupôs, como indicativo para a operacionalização do Programa, a implementação de Serviços e ou Centros de Referência, estruturas 
dotadas de recursos físicos e humanos para o atendimento e acompanhamento especializado ao público em situação de violência sexual - crianças, adolescentes e suas famílias.

As ações desenvolvidas, no âmbito do Programa Sentinela, seriam voltadas para a atenção à família, “(...) a qual deve ser trabalhada por meio de ações sociais especializadas, atendimento psicossocial, orientação, e acompanhamento permanente, que visem garantir a sua proteção e inclusão social” (BRASIL, 2001, p.3). O Sentinela, deste modo, antecipou contornos significativos da PSE de média complexidade, considerando a previsão do atendimento especializado por meio de Serviços e Unidades de Referência, a centralidade das intervenções na família e o pressuposto da atuação integrada à rede de atendimento intersetorial.

No tocante às distinções introduzidas pela PNAS/2004, destaca-se o diferencial quanto aos enunciados do fenômeno da violência - revestido de um investimento específico, a violência sexual, no Programa Sentinela, para uma intervenção de cunho ampliado, a depender dos determinantes atrelados às situações de risco pessoal e social. Aqui cabe reportar a crítica, tecida no Capítulo I, sobre a atualização do vocabulário da Política de Assistência Social, ao assumir o pressuposto do risco e as situações de vulnerabilidade como premissas da intervenção socioassistencial, tendência que, na compreensão de Behring, estabelece

(...) para os que estão em situação de pauperização absoluta - pela novilíngua, parafraseando George Orwell, da política social contemporânea, em situação de risco ou de vulnerabilidade - a assistência social e os PTRC assumiram na política social dos tempos de neoliberalismo um importante papel, considerando seu baixo custo e alto impacto político e econômico, ainda que não alterem a desigualdade funcional de renda (...)" (2016, p.23)

A análise, voltada para a apropriação do fenômeno da violência no referencial da PNAS/2004, identifica o cenário retratado pela autora, a partir da adoção de nomenclaturas inéditas, em substituição ao recorte por situações de violência específicas. Os tópicos, referentes à fundamentação da PSE de média complexidade, assumem as situações de risco como justificativas da intervenção especializada da Assistência Social, acrescido do critério de preservação dos vínculos relacionais e de pertencimento. Para a PNAS/2004, os serviços da PSE de média complexidade são destinados às famílias e indivíduos em situação de risco 
pessoal e social, mas cujos vínculos familiar e comunitário não foram rompidos (BRASIL, 2004).

É pertinente, dado o movimento de diálogo com as normativas, recuperar as problematizações de Sposati (2004), autora que constata a fragilidade das análises da categoria risco na Assistência Social. Ressalta, ao situar as ambiguidades presentes nas definições das necessidades atendidas pela Política, a incorporação do risco social, demarcando apropriações conflitantes do conceito:

As culturas liberal e neoliberal entendem o risco como uma questão de preocupação pessoal e individual. As incertezas da vida, de acordo com o pensamento liberal, devem ser enfrentadas e respondidas por cada um, de acordo com as suas possibilidades. É preciso o compromisso coletivo da sociedade com os riscos sociais da população (...). Não se rompe o circuito de sociedade de risco na qual o trabalhador é que deve ser o provedor da superação do risco (SPOSATI, 2004, p. 44).

A tradução de risco, nos termos da PNAS/2004, incide na identificação de distintas expressões da violência, apropriadas como eventos que se manifestam nas relações familiares e/ou interpessoais. Ao exemplificar as situações que denotam riscos, tais como o abandono, maus tratos físicos e psíquicos, assim como o próprio abuso sexual, a normativa faz alusão ao fenômeno, ainda que não o nomeie. No entanto, privilegia recortes específicos das potenciais vítimas e relações violadoras, bem como situa a família como ator privilegiado de proteção. Aqui se estabelece a tônica da PSE de média complexidade, determinante para a implementação, avaliação e formação continuada da Política: a família como instância que vivencia, reproduz, protege e, recorrentemente, é responsabilizada por distintas expressões de violência que atravessam as relações privadas e interpessoais.

A PNAS/2004, decerto, representa a principal referência dos documentos de formulação, de modo que as linhas de atuação da PSE, formuladas no período de transição entre a cobertura assistencial de segmentos específicos para a atenção especializada mediada por serviços socioassistenciais, seguem como referência, considerando que as normativas posteriores - NOB 2005 e 2012 e LOAS/2011 preservam a correlação entre contextos de risco e as expectativas de proteção delegadas às famílias. 
As situações de risco demandarão intervenções em problemas específicos e, ou, abrangentes. Nesse sentido, é preciso desencadear estratégias de atenção sociofamiliar que visem a reestruturação do grupo familiar e a elaboração de novas referências morais e afetivas, no sentido de fortalecê-lo para o exercício de suas funções de proteção básica ao lado de sua auto-organização e conquista de autonomia. (BRASIL, 2004, p. 37)

A família é o núcleo social básico de acolhida, convívio, autonomia, sustentabilidade e protagonismo social; e, a família deve ser apoiada e ter acesso a condições para responder ao seu papel no sustento, na guarda e na educação de suas crianças e adolescentes, bem como na proteção de seus idosos e portadores de deficiência. (BRASIL, 2004, p. 90)

A LOAS/2011, em adição, ao definir a organização da PSE, estabelece que tal eixo protetivo organiza um conjunto de serviços, programas e projetos, cujo objetivo se volta para a reconstrução de vínculos familiares e comunitários, o fortalecimento das potencialidades e aquisições e a proteção de famílias e indivíduos para o enfrentamento das situações de violação de direitos (BRASIL, 2011). Ou seja, a versão atualizada da Lei Orgânica recupera a dimensão dos vínculos e agrega a violação de direitos na esfera legislativa da Política, contemplando a síntese das definições sobre a capacidade protetiva das famílias na PSE.

A partir da observação sobre o desenvolvimento das definições da PSE nas normativas de formulação, a análise destaca a referência à matricialidade sociofamiliar, tomada como eixo estruturante do SUAS. A orientação sustenta a centralidade das ações da Política de Assistência Social nas famílias, premissa que estrutura a organização da PSB e PSE. Nesse contexto, a família é caracterizada na PNAS/2004 como “(...) espaço privilegiado e insubstituível de proteção e socialização primárias, provedora de cuidados aos seus membros, mas que precisa também ser cuidada e protegida" (BRASIL, 2004, p.41).

O documento reconhece a diversidade de formatos e modelos de famílias, na função de mediação entre os sujeitos e a coletividade. Adverte que a dinâmica das relações familiares é atravessada por processos contraditórios, com repercussões para convivência cotidiana, a qual pode ser marcada por conflitos e desigualdades. Somado ao esforço por ampliar o repertório das conformações familiares, a PNAS/2004 adotou como prerrogativa o fortalecimento de vínculos familiares e comunitários, tomados como medidas de transição entre a PSB e PSE. 
Para tanto, reforçou que "a ética da atenção da proteção especial pressupõe o respeito à cidadania, o reconhecimento do grupo familiar como referência afetiva $\mathrm{e}$ moral e a reestruturação das redes de reciprocidade social” (BRASIL, 2004, p. 37).

As normativas subsequentes reiteram o significado da matricialidade familiar para a proteção social de Assistência Social, como a NOB 2005, ao reafirmar o lugar da família como o núcleo social básico de acolhida, convívio, autonomia, sustentabilidade e protagonismo social, e a LOAS, ao referendar o discurso que normaliza a capacidade protetiva das famílias. Nos documentos de formulação, é possível reconhecer uma referência que exacerba o protagonismo da família na Política, tendência que repercute nos documentos de execução, quando a centralidade da intervenção nas relações familiares passa a justificar a avaliação de transgressões, pautadas sob a ótica de um lugar idealizado de proteção.

A investigação, ao abordar a relação estabelecida entre a diretriz da matricialidade familiar e as situações risco e/ou violações de direitos nos documentos, reconheceu, na definição do público alvo da PNAS/2004, cidadãos e grupos que se encontram em situações de vulnerabilidade e riscos, tais como: famílias e indivíduos com perda ou fragilidade de vínculos de afetividade, pertencimento e sociabilidade; e com vivência de diferentes formas de violência advindas do núcleo familiar. $\mathrm{O}$ documento reforça a apropriação da violência atrelada ao núcleo familiar e às relações interpessoais, quando da definição do público usuário da Política - orientação que repercutirá, em especial, na operacionalização dos serviços da PSE de média complexidade e nos documentos de sistematização e monitoramento do PAEFI.

Nesse contexto, coloca-se em questão a inserção das famílias como partícipes da provisão de bem-estar, desencadeando o que Mioto et al (2015) denominam como a responsabilização da família no campo da política social. Para as autoras, a perspectiva do familismo sustenta a família como instância principal de proteção, imputando-lhe consensos e pactuações em torno da responsabilidade que lhe é destinada. Em consequência, a partir das atribuições acordadas como encargos das famílias, é possível “(...) desautorizá-las à medida que não correspondam às expectativas colocadas sobre seu papel e culpabilizá-las pelos seus fracassos, podendo chegar à sua judicialização" (MIOTO, 2016, p. 20) 
Com efeito, o estudo das normativas problematizou como os documentos relacionam a atuação da PSE de média complexidade com o Sistema de Justiça, sendo possível constatar que o elo se apresenta como prerrogativa da atenção especializada desde a promulgação da PNAS/2004. Ao anunciar a PSE enquanto modalidade de atendimento assistencial destinada a famílias que se encontram em situação de risco pessoal e social, por ocorrência de violações que remetem a expressões de violência intrafamiliar, a PNAS/2004 e as normativas do campo da formulação assumiram uma expectativa de intervenção voltada para os grupos que falharam em suas funções precípuas de proteção, seja pela omissão ou como o próprio agente violador.

A garantia da reestruturação familiar, ou, nos termos da Política, da recuperação de sua capacidade protetiva, ascende como um atributo das seguranças socioassistenciais ligadas à PSE. Porém, diante da complexidade que se apresenta para as mudanças e correções de trajetórias, a Política reconhece que os serviços de proteção especial possuem “(...) estreita interface com o sistema de garantia de direitos exigindo, muitas vezes, uma gestão mais complexa e compartilhada com o Poder Judiciário, Ministério Público e outros órgãos e ações do Executivo" (BRASIL, 2004, p. 37).

A NOB 2005 orienta, enquanto princípio organizativo do SUAS, a articulação interinstitucional de competências e ações complementares com o Sistema Nacional e Estadual de Justiça para garantir proteção especial a crianças e adolescentes nas ruas, em abandono ou com deficiência, sob decisão judicial de abrigamento pela necessidade de apartação provisória de pais e parentes, por ausência de condições familiares de guarda, dentre outras motivações. A normativa sinaliza a articulação entre os sistemas e ações complementares para garantir a proteção especial, destacando os limites e o próprio sentido da incompletude institucional - interpretação necessária, inclusive, para contrapor a expectativa generalista de proteção social que se confere à Assistência Social ${ }^{47}$.

A LOAS/2011, ao demarcar a distinção entre as propostas de acompanhamento da PSB e PSE, situa o PAEFI enquanto Serviço de Acompanhamento, cuja intervenção se sustenta no apoio, orientação e

47 Debate crítico abordado no Capítulo I. 
acompanhamento de famílias e indivíduos em situação de ameaça ou violação de direitos, articulando os serviços socioassistenciais com as diversas políticas públicas e com órgãos do Sistema de Garantia de Direitos (SGD) (BRASIL, 2011). A definição explicita o desenvolvimento da abordagem da PSE de média complexidade nos documentos de formulação, considerando a incorporação da nomenclatura PAEFI, ao passo que a PNAS e a NOB 2005 não haviam estipulado, com precisão, o desenho normativo do serviço de acompanhamento de tal segmento da Proteção Especial ${ }^{48}$.

E, quando o fez nos documentos de formulação ${ }^{49}$, a partir da revisão do texto da Lei Orgânica, estabeleceu a relação com órgãos do SGD, identificados a partir da referência às instâncias de promoção e defesa de direitos. Os contornos dessa relação serão explorados na apreciação dos documentos da operacionalização e avaliação, a considerar o papel de relevância do Sistema de Justiça na articulação intersetorial perseguida pelo PAEFI. Por ora, vale destacar o deslocamento da menção ao Poder Judiciário e do Sistema de Justiça nos documentos precursores para a referência ao SGD na LOAS e NOB/2012

A substituição é interpretada como um processo de amadurecimento e autocrítica dos documentos que orientam a concepção da PSE. A revisão dos termos é apreendida como um investimento que reafirma a relação de transversalidade da Política como integrante do SGD, o qual se pauta pela perspectiva de integração entre as instâncias que compõem os eixos da promoção, defesa e controle dos direitos de crianças e adolescentes ${ }^{50}$. Trata-se de um movimento que observa a tendência dos documentos de operacionalização, os quais, a partir de $2011^{51}$,

48 A PNAS/2004 documento identifica o Serviço de Orientação e Apoio Sociofamiliar enquanto serviço que responde pela proposta de acompanhamento familiar e individual do CREAS. Portanto, trata-se da versão que antecedeu o PAEFI. A cobertura do Serviço de Orientação e Apoio Sociofamiliar não é detalhada na PNAS/2004, tampouco na NOB/2005.

49 Importa destacar que a apresentação do PAEFI é anterior à LOAS/2011. O formato é institucionalizado na Tipificação Nacional dos Serviços Socioassistenciais, em 2009.

50 De acordo com Baptista, "um princípio norteador da construção de um sistema de garantia de direitos é a sua transversalidade. Seus diferentes aspectos são mutuamente relacionados, e as reflexões, os debates e as propostas de ações no sentido de garanti-los apenas alcançarão a eficácia pretendida se forem abordados integradamente de forma a fortalecer as iniciativas das suas diferentes dimensões (2012, p.188).

51 As Orientações Técnicas do CREAS, publicação de 2011, pontuam, de forma inédita, dificuldades e limites da relação com o Judiciário. A normativa será analisada no tópico subsequente. 
problematizam a relação coerciva de órgãos da Justiça com a PSE de média complexidade, com significativas repercussões para o PAEFI.

Os documentos sinalizam, assim, um movimento de reação ao atravessamento do Sistema de Justiça nas intervenções da Política, traço que remonta ao histórico punitivo das ações assistenciais no país. Ao reivindicar o lugar da proteção, a partir da atuação integrada com distintas políticas setoriais e com recursos do SGD, a PSE de média complexidade acena para a garantia de direitos das famílias. No entanto, a correção de rotas nos documentos tende a não ser suficiente para reverter os rebatimentos de controle que se colocam para as famílias pobres, uma vez que a Política tende a demarcar um discurso de defesa e acesso a direitos no plano institucional, mas corrobora com práticas cotidianas que vinculam a violência como traço esperado destas relações familiares.

A pesquisa apurou, ao indagar quais marcadores de violência os documentos indicam para a sistematização dos registros da PSE de média complexidade, a relevância do segmento de Vigilância para a Política, em que pese o investimento na produção de indicadores específicos do (e para o) campo socioassistencial. A estrutura, anunciada na PNAS/2004 e NOB/2005 como Vigilância Social, e, a partir da LOAS/2011 e NOB 2012, como Vigilância Socioassistencial, é decisiva para a consolidação do SUAS, ao parametrizar a oferta, o registro, a cobertura, o monitoramento, o repasse de recursos, dentre outros aspectos, em âmbito nacional.

No entanto, a análise dos pressupostos da Vigilância detidos à PSE remete ao descompasso apontado entre a defesa institucional dos termos da Política e as prerrogativas do acompanhamento familiar cotidiano. Na PNAS/2004 e na NOB 2005, a Vigilância Social, definida como referência para a organização dos serviços socioassistenciais, constrói indicadores das situações de vulnerabilidade e risco pessoal e social que incidem sobre famílias e indivíduos, nos diferentes ciclos de vida (crianças, adolescentes, jovens, adultos e idosos), assim como identifica a incidência de crianças, adolescentes, jovens, adultos e idosos vítimas de formas de exploração, de violência, de maus tratos e de ameaças.

Na perspectiva da LOAS/2011 e da NOB 2012, a definição da Vigilância Socioassistencial, aqui já com a mudança de nomenclatura, retoma a direção do trabalho das Proteções, considerando a perspectiva de analisar territorialmente a 
capacidade protetiva das famílias e nela a ocorrência de vulnerabilidades, de ameaças, de vitimizações e danos. A Vigilância Socioassistencial guarda estreita vinculação à PSE de média complexidade, tendo em vista a análise dos territórios baseada no critério de mapeamento das vitimizações e danos, em especial aqueles perpetrados pelas famílias.

Nesse cenário, a Vigilância Socioassistencial objetiva estabelecer critérios de mensuração da capacidade protetiva das famílias, bem como se propõe ao estudo dos territórios, de modo a determinar as situações de risco, conforme critérios estabelecidos pela Política. Exercita, portanto, recortes das famílias e dos territórios sob análise, desconsiderando o atravessamento interseccional das desigualdades de classe, raça, gênero, nacionalidade e geração dentre o público que acessa a rede socioassistencial. Pautada nos critérios de riscos e violações, vividos por e perpetrados pelas famílias, a Vigilância Socioassistencial se propõe a produzir dados que demarcam expectativas de proteção, com marcadores que consideram a violência como traço previsível nas relações das famílias vulneráveis.

A violência se coloca como fenômeno a ser mensurado pela Política de Assistência Social, embora as normativas não deliberem, na fase de formulação da PSE de média complexidade, a violência intrafamiliar como categoria de referência para a proposta de intervenção e acompanhamento do PAEFI. As situações de risco pessoal e social acrescidas, a posteriori, da conjunção conclusiva por violação de direitos, definem o escopo e as coberturas atribuídas ao PAEFI, embora a produção de dados contemple a violência como marcador que fragiliza a dita capacidade protetiva das famílias. Aqui a centralidade da família retorna, como premissa para o planejamento dos serviços, tanto como para a apuração do exercício do cuidado a ela delegado.

\subsection{2.}

\section{A violência nos documentos de implementação: as expressões da violência como situações de risco e violação de direitos.}

Os documentos da etapa de implementação da Política de Assistência Social materializam os referenciais anunciados no eixo de formulação, explorados no tópico anterior. A fase da execução objetiva materializar pactuações firmadas no 
plano institucional, de modo a aplicar o planejamento da Política às ações cotidianas das unidades e serviços socioassistenciais. A etapa submete as intencionalidades da Assistência Social ao percurso da execução, caminho que pode validar o planejamento das rotas, apontar limites, sugestionar adaptações e até mesmo redirecionar o trajeto idealmente traçado.

O estudo do processo de implementação da Assistência Social, com destaque para a abordagem da violência na PSE de média complexidade, contemplou o Guia de Orientação do CREAS/2006, a Tipificação Nacional dos Serviços Socioassistenciais, as Orientações Técnicas do CREAS/2011 e a Nota Técnica SUAS e Sistema de Justiça. As publicações selecionadas normatizam a execução da PSE de média complexidade, contudo, a análise se ,deteve, especificamente, às regulamentações do PAEFI, considerando o recorte do objeto da pesquisa - o qual problematiza a violência como campo de intervenção da Política de Assistência Social, a partir do acompanhamento especializado sob a responsabilidade do CREAS.

Nesse sentido, o investimento inicial do estudo se concentrou em identificar as definições de violência presentes nos documentos de regulamentação do CREAS e, em desdobramento, do PAEFI. Os Guias de implementação do CREAS, publicados em 2006 e 2011, assim como a Tipificação Nacional seguem a tendência de citar expressões de violência, vinculadas às dinâmicas familiares, sem a perspectiva de esmiuçar os sentidos que orientam a apropriação de tais categorias no PAEFI. É possível questionar, diante das ausências de interpretações acerca do fenômeno, se caberia às normativas de execução explorarem suas significações, considerando que os documentos de formulação acenaram para categorias distintas, como risco e matricialidade sociofamiliar, por exemplo.

O contra argumento para esta ponderação recupera extratos das Orientações Técnicas/2011, normativa que incorpora o processo de amadurecimento do SUAS, ao avançar em proposições que particularizam a PSE de média complexidade, em contraponto com os registros de 2006 e $2009^{52}$,

52 A análise identificou que as publicações do período imediato à PNAS/2004 estruturam argumentos para determinar as diferenças entre a PSB e PSE, tendo o padrão do vínculo familiar como determinante. A título de de ilustração, destaca-se a experiência do município do Rio de Janeiro, onde as versões precursoras dos serviços especializados da PSE, como a Abordagem Social 
documentos que ainda sustentam as diferenciações entre os serviços da PSB e PSE. A publicação, ainda no capítulo de abertura, detalha as categorias território, vulnerabilidade e risco social, recuperando as produções de referência da PNAS/2004:

As categorias território, vulnerabilidade social e risco social são fundamentais para compreender os elementos diretamente relacionados às competências da assistência social e a organização do SUAS. Tais categorias devem ser compreendidas a partir de uma abordagem multidimensional que propicia a análise das relações entre as necessidades e demandas de proteção social em um determinado território e as possibilidades de respostas da política de Assistência Social, em termos de oferta de serviços, programas e benefícios à população. (BRASIL, 2011, p. 14)

O documento reforça a diretiva dos documentos de referência da Política, explicitando como pauta da PSE de média complexidade as situações de risco social, por violação de direitos - definição corrente desde 2009, quando a Tipificação Nacional definiu as nomenclaturas e encaminhamentos dos serviços socioassistenciais, por eixo protetivo. O fenômeno da violência e a violação de direitos permanecem com uma abordagem secundária, posto que a categoria risco ascende como determinante para a definição das competências da PSE. Sendo assim, a normativa responsável por detalhar as orientações da unidade assistencial que materializa a PSE de média complexidade, sustenta que

Com base na PNAS (2004), pode-se ressaltar que, no âmbito de atuação da Assistência Social, as situações de risco pessoal e social, por violação de direitos, se expressam na iminência ou ocorrência de eventos como: violência intrafamiliar física e psicológica, abandono, negligência, abuso e exploração sexual, situação de rua, ato infracional, trabalho infantil, afastamento do convívio familiar e comunitário, idosos em situação de dependência e pessoas com deficiência com agravos decorrente de isolamento social, dentre outros. (BRASIL, 2011, p.14)

No tocante às projeções do acompanhamento da PSE de média complexidade, os guias de implementação, em especial, apresentam distinções quanto às motivações dos atendimentos especializados. Como mencionado, o primeiro Guia de Orientação, publicado em 2006, persegue a organização de uma estrutura inédita, baseada na premissa da especialização no rol das ofertas experiência vivida pela própria pesquisadora, enquanto Assistente Social da Prefeitura da Cidade do Rio de Janeiro (PCRJ). 
socioassistenciais. A avaliação do documento dimensionou o contexto da normativa, que exercitou a transposição dos serviços destacados da Política, afeitos a segmentos e públicos específicos, como a Abordagem Social e o Sentinela, para uma unidade de caráter intermediário, inédita na Assistência Social - o CREAS.

A normativa encaminha definições que se sobrepõem, como no caso do registro da PSE de média complexidade, a partir da descrição do CREAS. De acordo com o documento, o CREAS, como integrante do SUAS, constitui o polo de referência, coordenador e articulador da PSE de média complexidade, responsável pela "oferta de orientação e apoio especializados e continuados de Assistência Social a indivíduos e famílias com seus direitos violados, mas sem rompimento de vínculos" (BRASIL, 2006, p. 4). A partir da definição, constata-se a fragilidade dos vínculos ainda como critério determinante para a PSE de média complexidade, conforme delimitação expressa na PNAS/2004 e NOB 2005.

Ao descrever as situações e ocorrências que justificam a intervenção da PSE, o Guia registra um apontamento fundamental para a interpretação do recorte de violência que delimita a intervenção da Política - "este campo de proteção na Assistência Social se ocupa das situações pessoais/familiares com ocorrência de contingências/vitimizações e agressões, cujo nível de agravamento determina seu padrão de atenção" (BRASIL, 2006, p. 3).

Trata-se de uma definição que vincula o campo de intervenção da Política às expressões de violência manifestas nas relações familiares e/ou interpessoais reconhecimento que permanece em suspenso nos documentos da Proteção Especial subsequentes. Como resultado da pesquisa, cabe antecipar que a admissão da violência, a partir de um viés específico, qual seja, as expressões do fenômeno nas relações familiares e interpessoais, como campo eleito para a intervenção da Assistência Social, retorna no documento de formação continuada, de 2018 abordado no último tópico da análise. Os documentos de implementação estudados, do período de 2009 a 2016, não estabelecem essa delimitação do campo de intervenção da PSE de média complexidade.

Cabe salientar que, no primeiro momento de implementação do CREAS, a Unidade ofertou atendimento às situações de risco e violação de direitos de crianças e adolescentes e o atendimento a adolescentes em cumprimento de medida socioeducativa em meio aberto. À época, os serviços dos CREAS voltados para o 
acompanhamento familiar eram: Serviço de Enfrentamento à Violência, Abuso e Exploração Sexual contra Crianças e Adolescentes; Serviço de Orientação e Apoio Especializado a Indivíduos e Famílias com seus Direitos Violados; e Serviço de Orientação e Acompanhamento a Adolescentes em Cumprimento de Medida Socioeducativa de Liberdade Assistida e de Prestação de Serviços à Comunidade.

Os contornos iniciais do acompanhamento familiar, na dinâmica da PSE de média complexidade, incorporou as premissas do Sentinela e da MSE em meio aberto, considerando a intervenção em contextos de violação dos direitos de crianças e adolescentes e, por extensão, o investimento em medidas de recuperação da capacidade protetivas das famílias (BRASIL, 2006). O CREAS, nesse cenário, ofertaria atenções na ocorrência de situações de risco pessoal e social por ocorrência de negligência, abandono, ameaças, maus tratos, violência física, psicológica, e sexual, prestando atendimento prioritário a crianças, adolescentes e suas famílias (BRASIL, 2006).

O encadeamento da atenção específica para o direcionamento amplo às situações de risco é identificado no documento, na medida em que agrega as modalidades de atendimento para crianças e adolescentes vítimas, como os serviços de acompanhamento voltados para a família. De todo modo, a abordagem ainda sustenta a centralidade das ações na criança e no adolescente vítima, em aparente descompasso com a diretriz da matricialidade proposta pela PNAS/2004.

A família é pensada a partir da responsabilidade patente de exercer o cuidado, enquanto núcleo estratégico para a garantia de direitos, sobretudo de crianças e adolescentes. A centralidade assenta-se na responsabilização, tendo em vista o direcionamento de ações para o fortalecimento da dita capacidade de proteção. Aliás, a anunciada aptidão protetiva torna-se um mantra da Política, o qual, independente do formato dos documentos, ou, do desenho normativo do serviço de acompanhamento da PSE de média complexidade, retorna como essência a ser perseguida pela intervenção especializada.

O PAEFI assume a referência do acompanhamento familiar do CREAS em 2009, a partir da publicação da Tipificação Nacional dos Serviços Socioassistenciais. O documento o definiu como serviço de apoio, orientação e acompanhamento a famílias com um ou mais de seus membros em situação de ameaça ou violação de direitos. Segundo a normativa, o PAEFI compreende 
atenções e orientações direcionadas para a promoção de direitos, a preservação e o fortalecimento de vínculos familiares, comunitários e sociais e para o fortalecimento da função protetiva das famílias diante do conjunto de condições que as vulnerabilizam e/ou as submetem a situações de risco pessoal e social (BRASIL, 2009).

Em contraponto ao formato do acompanhamento disposto no Guia de Implementação/2006, a Tipificação estrutura o PAEFI na perspectiva da violação de direitos, em substituição ao enfoque nas famílias com vínculos frágeis. A despeito da mudança quanto ao direcionamento das ações, o serviço preserva o sentido de suas atenções detidas ao fortalecimento da capacidade protetiva das famílias. Destaca-se, ainda, a conexão que o documento estabelece ao relacionar as expressões de violência como violações de direitos - paralelo inédito nas normativas da PSE, reconhecido como um movimento que qualifica a abordagem do fenômeno, para além das menções que o descrevia como exemplos de situações de risco.

Ainda que não supere um pretenso didatismo na abordagem da violência, tendo em vista que a Tipificação ainda detalha aspectos do fenômeno como consequências das situações de risco, o vínculo com a dimensão da violação de direitos possibilita uma análise política das expressões relacionadas à dinâmica familiar. Cabe salientar que a interpretação remete ao ponto de vista explorado na pesquisa, detido em avaliar a abordagem e definições que circundam a violência na Política, uma vez que os documentos, com exceção da normativa de formação continuada, prescindem de análises acerca dos enfoques estruturais da violência e da violação de direitos.

Se é possível apontar um registro de destaque para a PSE de média complexidade, o documento, ao assumir a responsabilidade de estabelecer parâmetros unificados para os serviços socioassistenciais, alinha uma intervenção pautada na diretriz da matricialidade sociofamiliar, que, por vezes, incorre num direcionamento moralizador para a PSE. No PAEFI, os objetivos do Serviço se voltam para o fortalecimento da dita capacidade protetiva, bem como para romper com padrões violadores de direitos no interior da família - ou seja, a centralidade das ações se estabelece no planejamento detido à esfera familiar, o qual encerra tanto investimentos por parte da Assistência Social, como mecanismos de controle 
de práticas e questionamento do referencial de cuidado das famílias em situação de vulnerabilidade. Ressalta-se, aqui, a dualidade entre a perspectiva de proteção e um padrão de crítica moral, que coloca sob suspeita o referencial de cuidado das famílias, perpetrado pelo PAEFI.

No Guia de Implementação do CREAS, publicado em 2011, o referencial da situação de risco, por violação de direitos, encontra-se consolidado para a PSE de média complexidade. O documento avança, assim, por esmiuçar o sentido da incompletude da intervenção do PAEFI, sinalizando a complexidade que o contexto de risco impõe à PSE de média complexidade. A normativa sinaliza os limites da atuação da Assistência Social, considerando a enredamento das situações de risco por violação de direitos:

É importante ressaltar que o enfrentamento das situações de risco pessoal e social, por violação de direitos, não compete unicamente à Política de Assistência Social, pelo contrário, sua complexidade exige a articulação e o desenvolvimento de ações complementares com outras políticas sociais e órgãos de defesa de direitos, para proporcionar proteção integral às famílias e aos indivíduos. (BRASIL, 2011, p. 15)

Parte-se do reconhecimento da complexidade, no entanto, as normativas da PSE de média complexidade, que assumem a dimensão do risco pessoal e social, desde 2004, e, a partir de 2009, atrelada à violação de direitos, não embasaram conceitualmente o campo que reivindicam como próprio. A complexidade é anunciada a partir uma leitura espontânea, uma vez que as expressões que materializam a violação de direitos e, em consequência o fenômeno da violência, são negligenciados nos documentos que estruturam o campo de intervenção da Política - sendo explorados, tão somente, nos documentos que orientam o registro e a avaliação das intervenções socioassistenciais do PAEFI ${ }^{53}$. Tendência que sugere um direcionamento acrítico no campo da formulação e execução, respaldado pela abordagem descritiva das publicações do eixo do monitoramento e avaliação.

Em complemento, o documento reforça o desenho normativo, formalmente definido pela Tipificação Nacional, no qual a PSE de média complexidade organiza a oferta de serviços, programas e projetos de caráter especializado, que requerem maior estruturação técnica e operativa (BRASIL, 
2011). Sublinha, ao longo das justificativas da publicação, o perfil de especialização atribuído ao acompanhamento técnico do PAEFI, em razão da prerrogativa do atendimento às situações de risco, por violação de direitos.

A normativa pressupõe que, devido à natureza e ao agravamento destas situações, a PSE de média complexidade oferta acompanhamento especializado, individualizado, continuado e articulado com a rede. $\mathrm{O}$ documento ressalta a definição da PSE de média complexidade, em destaque nos documentos de formulação, que se volta para o acompanhamento especializado, articulado às demais políticas públicas e ao SGD - encaminhamento que se mantém nos documentos de monitoramento e avaliação, como no eixo de formação continuada da Política.

A discussão sobre a matricialidade sociofamiliar, abordada no Guia de Implementação de 2011, parte de uma interpretação já amadurecida da temática, de modo que o documento busca explorar uma posição de defesa, suscitada por possíveis críticas acerca da intervenção orientada por esta diretriz da Política. Para ilustrar tal assertiva, cabe o destaque para o seguinte posicionamento:

A centralidade das ações na família visa compreender, em um determinado contexto, como se constroem e se expressam as relações familiares entre seus membros. Essa perspectiva não visa responsabilizar a família e seus componentes no tocante às vicissitudes que vivenciam no seu cotidiano, mas contextualizar a situação vivida e recolocar o papel do Estado como provedor de direitos por meio das políticas sociais, fornecendo instrumentos de apoio e sustentação necessários para a proteção social das famílias. (BRASIL, 2011, p. 33)

Os argumentos corroboram o esforço da normativa em situar as contradições que atravessam as famílias, demarcando uma posição de defesa da perspectiva de proteção na esfera pública, que se volta à prerrogativa do Estado e das políticas sociais. Aqui se reafirma a lógica paradoxal que pavimenta o acompanhamento especializado do PAEFI, uma vez que envida a perspectiva protetiva, ao balizar sua intervenção articulada às garantias das demais políticas públicas, como pode reforçar a perspectiva do controle, quando o pêndulo das intervenções se volta para as determinações do Sistema de Justiça, priorizando a esfera da responsabilização, pautada num ideário de proteção que desconsidera desigualdades estruturais. 
O trabalho social com centralidade na família no CREAS visa ao fortalecimento da sua função de proteção e atenção a seus membros, prevenindo, mediando e fortalecendo condições para a superação de conflitos. Essa perspectiva é fundamental para prevenir a recorrência e/ou agravamento de processos que gerem e/ou acentuem situações de violência, abandono, negligência ou qualquer outro tipo de situação de risco pessoal e social, por violação de direitos. Nessa direção, o trabalho social proposto pelo CREAS deve primar pelo acesso das famílias e indivíduos a direitos socioassistenciais e inclusão na rede, tendo em vista o empoderamento e a potencialização de seus recursos e capacidade de proteção. (BRASIL, 2011, p. 34)

A centralidade na família implica, ainda, reconhecer que esta pode se configurar como um espaço contraditório, onde o lugar da proteção pode ser também o da violência e da violação de direitos. Nesse contexto, o empoderamento das famílias e de cada um de seus membros para o enfrentamento das situações poderá resultar na reconstrução das relações familiares ou, até mesmo, na construção de novas referências familiares e comunitárias, quando esta se mostrar a melhor alternativa para se assegurar proteção. (BRASIL, 2011, p. 35)

Os trechos acima mesclam a defesa da família como referência de proteção, como situam os atravessamentos violadores vivenciados e por ela perpetrados, demarcando importantes tensões que forjam as relações familiares contemporâneas. Faz-se necessário reconhecer a pertinência dos argumentos, em especial por problematizar e, por assim dizer, romper com o lugar idílico atribuído à família. Tal movimento é fundamental para complexificar a abordagem à família na Política, tanto para problematizar a expectativa da Assistência Social em potencializar a pretensa e naturalizada capacidade de proteção, quanto para reverter as posições que questionam o referencial de proteção balizado por famílias vulneráveis.

Contudo, vale advertir que tal movimento é necessário, também, para o sentido das intervenções do Estado, o qual ascende como um dos principais violadores de direito na contemporaneidade. E, por extensão, o Sistema de Justiça, o qual reclama a posição de defesa e preservação das garantias democráticas, mas, como destacado por Zaffaroni (2007), incute a lógica do controle e cerceamento de condutas e práticas, assim como o disciplinamento daqueles tomados como inimigos - lugar por vezes destinado às famílias e sujeitos vulneráveis, que agregam demais marcadores de desigualdade, na história da sociedade brasileira - conforme debate do Capítulo II.

A normativa explora o sentido da reparação amparado no envolvimento das redes de proteção, porém, cabe a indagação quanto aos eixos privilegiados do SGD, considerando a oscilação entre a lógica do acesso e a do controle. Como 
apontado no Capítulo I, faz-se necessário problematizar o alcance e materialidade dessa rede, dado o movimento de erosão da perspectiva pública de tais coberturas, além da focalização, que compromete a perspectiva de universalidade das políticas. A perspectiva de proteção, anunciada no PAEFI, considera esse esgarçamento?

Os documentos de execução sugerem uma proposta de rede sólida, a despeito dos recuos da perspectiva pública e avanço da lógica privatista contemporânea. O cenário atual impõe significativas tensões para o campo da proteção expresso pela PSE de média complexidade, o qual articula a dimensão privada (famílias e relações comunitárias) e pública (articulação intersetorial), ambas com consideráveis limites para afiançar as garantias previstas pela Assistência Social.

Nesse contexto, a investigação avançou para o mapeamento das garantias anunciadas pelo PAEFI, enquanto terreno das medidas de proteção da PSE de média complexidade. A análise da estrutura de argumentação das normativas de execução permite afirmar que a defesa da intervenção integrada à rede intersetorial, além do destaque à proteção desempenhada pelas famílias, são recorrentes no PAEFI, de modo que as proposições específicas da Assistência Social sustentam, em sua maioria, expedientes de cunho subjetivo - característica observável em todos documentos do ciclo de execução apreciados.

De acordo com o Guia de Implementação/2006, os serviços do CREAS ofertam ações de orientação, proteção e acompanhamento psicossocial individualizado e sistemático a crianças, adolescentes e famílias em situações de risco ou violação. No que diz respeito ao atendimento, orienta intervenções baseadas na ética e no respeito mútuo, com uma postura de acolhimento e escuta por parte dos técnicos, com vistas à criação de vínculos de confiança entre estes e as famílias atendidas (BRASIL, 2006). No tocante ao trabalho técnico, orienta a execução de procedimentos especializados, com o intuito de propiciar condições para o fortalecimento de identidade e autoestima, promover possibilidades de construção de propósitos de vida, o restabelecimento de vínculos familiares e sociais e o alcance de autonomia (BRASIL, 2006). 
A Tipificação Nacional, ao estabelecer as prerrogativas do PAEFI, alinha a expectativa de suas garantias a partir das seguranças socioassistenciais ${ }^{54}$. No eixo relativo à segurança de acolhida, determina que os usuários alcancem a reparação ou a minoração dos danos por vivências de violações e riscos sociais. No segundo tópico, segurança de convívio ou vivência familiar, comunitária e social, estipula que os usuários acessem serviços de outras políticas públicas setoriais, conforme necessidades (BRASIL, 2009).

Para a terceira segurança - desenvolvimento de autonomia individual, familiar e social, o documento propõe: oportunidades para superar padrões violadores de relacionamento; ter ampliada a capacidade protetiva da família e a superação das situações de violação de direitos; vivenciar experiências que oportunize relacionar-se e conviver em grupo, administrar conflitos por meio do diálogo, compartilhando modos não violentos de pensar, agir e atuar; ter acesso a experiências que possibilitem lidar de forma construtiva com potencialidades e limites (BRASIL, 2009).

O Guia de Implementação, publicado em 2011, encaminha as direções da Tipificação Nacional, enfatizando as garantias que a atenção especializada dos CREAS deveria assegurar, a saber: o fortalecimento da função protetiva da família; a construção de possibilidades de mudança e transformação em padrões de relacionamento familiares e comunitários com violação de direitos; a potencialização dos recursos para a superação da situação vivenciada e a reconstrução de relacionamentos familiares, comunitários e com o contexto social, ou construção de novas referências, quando for o caso; o empoderamento e a autonomia; o exercício do protagonismo e da participação social; o acesso das famílias e indivíduos a direitos socioassistenciais e à rede de proteção social; e a prevenção de agravamentos e da institucionalização (BRASIL, 2011).

O documento menciona, ainda, investimentos que a atenção especializada ofertada no CREAS mobilizaria com efeito de prevenção do agravamento das situações atendidas. Para tanto, prevê um conjunto de ações desenvolvidas na perspectiva da redução dos efeitos e consequências das situações de risco pessoal e

54 As seguranças socioassistenciais são anunciadas na PNAS/2004 e demais documentos da fase da formulação. A abordagem no tópico relativo à execução decorre de uma opção metodológica, adotada com o intuito de privilegiar a análise das garantias e aquisições socioassistenciais vinculadas ao PAEFI. 
social, por violação de direitos, vivenciadas pelos indivíduos e famílias sob acompanhamento no PAEFI (BRASIL, 2011). Nessa direção, a normativa complementa que, podem ser prevenidos, por exemplo, a perpetuação de ciclos intergeracionais de violência intrafamiliar ou até mesmo o agravamento da violência, “(...) a tal ponto que rupturas ou afastamento do convívio se mostrem as estratégias mais adequadas para assegurar proteção" (BRASIL, 2011, p. 28).

No período em relevo, as normativas de execução exploram aspectos similares, com a ressalva do privilégio da abordagem do vínculo em 2006 e a transição para a noção das seguranças socioassistenciais, a partir de 2009. Com efeito, a publicação das orientações precursoras do CREAS estipula intervenções pautadas no referencial do fortalecimento dos vínculos, tanto no âmbito das relações interpessoais, como na dinâmica de interação com os profissionais do CREAS.

As produções subsequentes, Tipificação e Guia de Implementação/2011, repercutem, para o plano operacional, a conversão das garantias da Política de Assistência Social para o contexto das seguranças socioassistenciais, conforme diretiva da PNAS/2004. O horizonte que se anuncia para a PSE de média complexidade, num contexto de garantias mediadas pelo viés da segurança, alçada à categoria da Assistência Social, exige a análise tanto da nomenclatura adotada para o campo socioassistencial, como dos pressupostos das garantias protetivas anunciadas.

Amorim (2015), ao analisar a relação entre as políticas de assistência social e criminal para o controle social exercido pelo Estado, sinaliza a conversão dos direitos sociais, expressos na PNAS/2004, à lógica das seguranças. Para a autora, tal nomenclatura é incorporada e associada à Assistência Social, ao imprimir um transformismo nos seus conteúdos (2015), o qual admite a apropriação de categorias relacionadas à Segurança Pública, considerando que as garantias socioassistenciais decorrem de seguranças - movimento que a autora igualmente identifica nas normativas da Política de Segurança Pública ${ }^{55}$,

55 A autora analisou os documentos nacionais e a execução orçamentária que tratam da Política de Assistência Social e da Política de Segurança Pública, mais precisamente o Programa Nacional de Segurança Pública com Cidadania (PRONASCI). O período analisado englobou os governos de Luiz Inácio Lula da Silva e Dilma Rousseff, contemplando os anos de 2003 a 2013. 
É por meio dessas seguranças que o usuário da assistência poderá desenvolver suas habilidades, capacidades, com mais liberdade e sem gerar dependência de recursos e de vínculos institucionais. De forma inversa, compete à Política de Segurança Pública promover a cidadania e possibilitar o acesso aos direitos sociais (...). É possível perceber que a segurança pública utiliza um volume de referências para o fortalecimento da cidadania e do acesso aos direitos sociais e, inversamente, a Assistência Social reforça a promoção de segurança. Esta inversão não se resume a termos técnicos, mas expressa a interface teóricoideológica do controle social (...) (AMORIM, 2015, p. 162).

As publicações de execução da PSE de média complexidade sustentam o avanço da Política para domínios subjetivos, na medida em que reivindica dispor do aporte necessário para direcionar e adequar projetos de vida das famílias e indivíduos de seu escopo de atuação. Amparada no discurso da proteção, a Assistência Social valida o atravessamento do Estado numa perspectiva que ultrapassa o marco regulatório das políticas sociais, na medida em que assume a prerrogativa de ajuste das relações, consideradas como inadequadas ou perigosas ou, nos termos da Política, como fatores de risco social e pessoal.

A despeito das problematizações que coletivizam os riscos, as seguranças socioassistenciais permanecem detidas à métrica do cuidado exercido pelas famílias. A centralidade da responsabilização retorna para a família e para o indivíduo, como objetivo primário da reparação de direitos no acompanhamento especializado do CREAS. Em tempo, cabe sublinhar o trecho que menciona a transformação dos padrões de relacionamento, o qual alimenta a expectativa que a intervenção especializada discipline condutas - síntese contundente para a análise do acompanhamento mediado pelo PAEFI.

A condição de vulnerabilidade das famílias inseridas na lógica do acompanhamento especializado do CREAS, aqui tomada pelo referencial de Zaffaroni (2001), habilita a intervenção da Assistência Social em dinâmicas privadas, que inspiram correções. A família assume, integralmente, a condição de perpetrar (e se colocar em) o risco às crianças e adolescentes, mulheres e idosos, por exemplo. A PSE de média complexidade cogita, em consequência, uma proposta de acompanhamento técnico assentado na revisão de condutas, a ser moldado por uma intervenção que restaure padrões de cuidado e responsabilidade nas relações familiares.

Para tanto, admite táticas de disciplinamento, de revisão de práticas, medidas que inspiram lógicas correcionais, sob a justificativa do amparo protetivo 
às famílias. Sem a pretensão de esgotar as nuances das seguranças socioassistenciais, vale pontuar que a proposta de acompanhamento do PAEFI é integrada à rede, fator que pode justificar ou induzir a vigilância do Sistema de Justiça nas pactuações firmadas na esfera do executivo da Política. Legitima-se, portanto, os termos da engrenagem punitiva na proposta de acompanhamento especializado do PAEFI, tal como explorado no Cap. 2.

A análise converge, nesse ponto, para a revisão das justificativas que balizaram a relação do SUAS com o Sistema de Justiça, no que diz respeito à PSE de média complexidade. Trata-se de reconhecer, de antemão, que as normativas sustentam os recursos da Justiça como retaguarda das intervenções socioassistenciais, ao longo do período de execução avaliado. A diferença que se apresenta, a partir de 2011, é o registro de ressalvas quanto à subordinação imposta por instituições do Judiciário, além do investimento por distinguir o lugar do CREAS no SGD, em especial dos serviços atrelados às instâncias de controle e responsabilização.

O primeiro Guia de Implementação do CREAS traz à tona o desenho de um eixo de acompanhamento especializado para a Assistência Social, estabelecido pela PNAS/2004, ao mesmo tempo que articula a transição dos serviços específicos para a compreensão ampliada das situações de risco. O estudo da normativa permitiu detalhar o contexto no qual a PSE de média complexidade vincula seu campo de atuação ao Sistema de Justiça, num panorama ainda incerto para a definição dos limites das respectivas atribuições, a considerar pela oferta de serviços e programas que condensavam orientações das Políticas Nacionais de 1998 e 2004.

De acordo com a publicação, o CREAS seria responsável pela orientação e encaminhamentos para a rede socioassistencial e de serviços especializados, garantindo a análise e atendimento de requisições de órgãos do Poder Judiciário e dos Conselhos Tutelares (BRASIL, 2006). A unidade socioassistencial é identificada como um ponto de suporte da Justiça, com a atribuição de incorporar os encaminhamentos por ela demandados, assim como de direcionamento de casos para a sua análise. A interpretação preliminar da normativa indica a disposição de uma articulação horizontal, de referência e contrarreferência das intervenções pactuadas entre o Executivo e Judiciário. 
(...) Durante o período de atendimento, destaca-se a necessidade de interlocução permanente com o sistema de garantia de direitos, com envio de relatórios periódicos, discussão quanto à evolução dos casos, e/ou solicitação, conforme a situação exigir, de novas medidas e procedimentos, como por exemplo, o afastamento do agressor do lar ou abrigamento provisório de crianças e adolescentes (BRASIL, 2006, p. 15).

No entanto, ao propor que as intervenções socioassistenciais sejam, de forma permanente, reportadas ao SGD, a publicação admite um ponto de contato que ultrapassa a interlocução, de modo a submeter suas intervenções a uma forma de supervisão consentida. É pertinente ponderar se o incentivo por reportar as intervenções do acompanhamento da PSE de média complexidade ao Sistema de Justiça não consistiria na busca de legitimidade e respaldo do lugar do CREAS, enquanto ator estratégico no SGD. De todo modo, o atravessamento forjou contornos problemáticos da relação do CREAS com o Sistema de Justiça, ressaltados no Guia de Orientações de 2011.

As orientações vigentes para a implementação do CREAS reiteram a importância da articulação com o Sistema de Justiça, assim como apontam as ressalvas que essa relação impõe. O documento reporta, ainda que não mencione de forma explícita, avaliações do período de operacionalização do CREAS, a partir da consolidação da PSE de média complexidade na estrutura do SUAS. À época da publicação, o Censo SUAS $2011^{56}$ divulgou um total de 2109 CREAS cadastrados, distribuídos nas cinco regiões do país (BRASIL, 2011). Portanto, os limites ressaltados dão conta do processo de implementação da PSE de média complexidade, sendo possível reconhecer na normativa uma tendência de revisão da inserção do CREAS no SGD.

Ao destacar o trabalho em rede, o documento sinaliza o princípio da intersetorialidade e da incompletude institucional, com ênfase num processo de articulação que fortaleça a complementaridade das ações dos CREAS com os diversos órgãos envolvidos no acompanhamento às famílias e indivíduos em situação de risco pessoal e social, por violação de direitos (BRASIL, 2011a). Aqui, posiciona o radar das intervenções apontado para a integração com políticas e projetos das demais políticas públicas e para a relação com os órgãos de defesa de

56 De acordo com a publicação, do total de 2.109 CREAS, 2.057 eram CREAS municipais e 52 CREAS regionais, com o registro de aumento de 519 unidades especializadas em comparação ao Censo SUAS 2010 (BRASIL, 2011). 
direitos - com a advertência que, caberia apenas aos últimos, a defesa e o cumprimento dos direitos, bem como a investigação e a responsabilização dos autores de violência (BRASIL, 2011a.).

Em complemento, a normativa sublinha, ao estabelecer as competências do acompanhamento especializado do CREAS, as particularidades que envolvem a sistematização das intervenções na dinâmica da PSE. De acordo com o texto, os relatórios podem dispor de informações sobre as seguranças afiançadas e “(...) quando couber, de outras informações, observando-se, necessariamente, sua pertinência, relevância e benefício para os usuários" (BRASIL, 2011a, p. 43). Tratase de um contraponto relevante, tendo em vista a orientação anterior, que previa o encaminhamento sumário dos registros socioassistenciais aos órgãos da Justiça.

A publicação define, enquanto competência do CREAS, o encaminhamento de relatórios ao sistema de defesa e responsabilização, desde que avaliados como necessários, por parte da equipe, ou quando solicitados, pelos órgãos do Sistema de Justiça. Para tanto, deverão resguardar as disposições éticas e orientações dos respectivos conselhos de categorias profissionais e atentar

(...) quando da sua elaboração, a função de proteção social da Assistência Social, bem como o papel do CREAS e suas competências que, de modo algum, poderão ser confundidos com o papel dos órgãos do sistema de defesa e responsabilização, a exemplo de delegacias e órgãos do Poder Judiciário. (BRASIL, 2011a, p. 43).

Os relatórios sobre o acompanhamento não devem se confundir com a elaboração de "laudos periciais", que constituem atribuição das equipes interprofissionais dos órgãos de defesa e responsabilização. Cabe ao CREAS, tão somente e quando necessário e/ou solicitado por estes órgãos, o encaminhamento de relatórios com informações gerais sobre os atendimentos realizados, resguardando-se o que dispõe o código de ética e as orientações dos respectivos conselhos de categoria profissional, bem como observando a função de proteção social da Assistência Social. (BRASIL, 2011a, p. 70).

Neste trecho, a publicação ressalta um ponto nevrálgico da atuação dos CREAS - a produção sob demanda dos órgãos do Sistema de Justiça. Como alternativa, propõe a pactuação de fluxos integrados entre os atores que compõem o SGD, estratégia que fortaleceria a identidade do CREAS junto às instâncias de 
defesa e responsabilização. Defende ${ }^{57}$, enfaticamente, que "a clarificação do papel e das competências do CREAS na rede é fundamental para se prevenir que os serviços ofertados sejam chamados a assumir funções para além daquelas que lhe concernem" (BRASIL, 2011a, p. 62).

Ainda que se reconheça a relevância dos investimentos para destacar as premissas do PAEFI, diante do acirramento das requisições advindas da esfera judicial, a análise refuta a interpretação da normativa, que encaminha a pactuação de fluxos como alternativa para superar os conflitos da relação entre a PSE de média complexidade e o Sistema de Justiça. O estudo pondera, diante dos resultados da pesquisa acerca de um acompanhamento especializado que admite práticas de controle e disciplinamento de condutas das famílias, se a política socioassistencial tende a incorporar aspectos complementares ao ordenamento punitivo das instituições do aparato jurídico-penal.

Mioto et al (2018) postulam que a análise dos processos de judicialização no campo da Assistência Social envolve a própria arquitetura do SUAS, pois, ao dispor de níveis de complexidade para a oferta dos serviços, relacionou-os à questão da violação de direitos como um processo ligado, primordialmente, à família. A PSB compreende a lógica de prevenção, cuja atenção volta-se para as famílias com vínculos preservados, em outras palavras, com capacidade de resposta às demandas de proteção social. Enquanto que a PSE oferta serviços para famílias que violam direitos, distinção que, para as autoras, “(...) provocam implicações não triviais nos processos interventivos e tem conduzido à intensificação dos processos de judicialização das famílias” (MIOTO et al, 2018).

A organização de uma gama de serviços direcionados às famílias que, a despeito das condições materiais e objetivas de reprodução e de trajetórias marcadas por processos de desigualdades estruturais, são responsabilizadas por não corresponderem às expectativas de proteção que lhe são imputadas, no âmbito da Assistência Social, admite a projeção de Wacquant (2013) sobre uma dupla

57 O documento sinaliza, ainda, que não cabe ao CREAS: “Ocupar lacunas provenientes da ausência de atendimentos que devem ser ofertados na rede pelas outras políticas públicas e/ou órgãos de defesa de direito; Ter seu papel institucional confundido com o de outras políticas ou órgãos, e por conseguinte, as funções de sua equipe com as de equipes interprofissionais de outros atores da rede, como, por exemplo, da segurança pública (Delegacias Especializadas, unidades do sistema prisional, etc), órgãos de defesa e responsabilização (Poder Judiciário, Ministério Público, Defensoria Pública e Conselho Tutelar) ou de outras políticas (saúde mental, etc.)". (BRASIL, 2011a, p. 25) 
regulação da pobreza, a partir da convergência da política assistencial e das instituições penais. Em diálogo com o autor, o estudo partilha a defesa que sustenta o controle da pobreza e o recrudescimento punitivo como elementos de uma única teia institucional, atrelados a processos que escamoteiam estratégias de controle, pela adoção de categorias que reivindicam garantias e direitos.

Cabe ressalvar que, o Guia de Implementação de 2011 arregimentou, de forma inédita, diversos aspectos sensíveis do processo de operacionalização do CREAS. Ao problematizar os limites do trabalho em rede, em especial com o SGD, no eixo de defesa e responsabilização, a publicação recuperou limites que remetem à transição dos serviços de acompanhamento por segmentos para o PAEFI processo que, decerto, demanda estudos complementares. Dito isto, a pesquisa sublinha que as reações críticas convergem para aspectos de uma defesa institucional do lugar e atributos do CREAS, quando a tendência por acentuar o controle das famílias em situação de pobreza não comparece com mesmo vulto nas problematizações encaminhadas pela Assistência Social.

Na esteira deste movimento crítico, em 2016, decorre a publicação da Nota Técnica SUAS e Sistema de Justiça, documento que demarca a posição da Política perante o atravessamento do aparato judicial nos processos de trabalho dos serviços e unidades. Para efeito da discussão, a análise se deteve ao diálogo com à PSE de média complexidade, eixo que abrange, em sua maioria, as medidas e práticas rechaçadas pelo documento. A normativa discrimina, enquanto procedimentos que extrapolam as funções da Política, medidas que caracterizam processos de investigação e responsabilização, tais como: realização de perícia, inquirição de vítimas e acusados, averiguação de denúncia de maus-tratos contra crianças e adolescentes, idosos, pessoas com deficiência e de violência doméstica contra a mulher (BRASIL, 2016).

A Nota Técnica ${ }^{58}$ afiança um marco de defesa, ao publicizar um registro de suma relevância para os profissionais envolvidos na dinâmica cotidiana da PSE de média complexidade. O estudo reitera os destaques conclusivos da normativa, considerando que quando órgãos do Sistema de Justiça exigem dos profissionais do SUAS a realização de atividades ou a sistematização de documentos não

58 Cabe sublinhar que a normativa foi elaborada apenas por representantes do Ministério do Desenvolvimento Social. 
condizentes com as suas atribuições ou com a missão e objetivos da Assistência Social (BRASIL, 2016), o caráter protetivo creditado à Política é fragilizado, posto que convertido em medidas de caráter investigativo e fiscalizador.

A análise dos documentos de implementação identificou elementos significativos da relação entre o SUAS e o Sistema de Justiça, suscitando um debate sobre o viés de controle que as sanções legais podem incutir ao público em acompanhamento especializado, como o cerceamento das práticas e imposição de limites à autonomia técnica dos profissionais vinculados ao CREAS. Como pontuado, a interpretação das normativas reconhece a relevância dos limites apontados nas produções recentes, não obstante, sinaliza que as problematizações privilegiam as repercussões institucionais, quando as medidas de cunho coercitivo dirigida às famílias carecem de visibilidade no exercício de crítica da Política.

Faz-se necessário ressalvar que a própria Política, nos contornos programáticos e normativos da PNAS/2004 e documentos posteriores, contribuiu para os descaminhos apurados, haja vista o panorama de riscos e processos violadores que determinam o seu público alvo e a adoção de medidas de reparação de direitos atreladas à esfera subjetiva e deliberações intersetoriais, com singular reforço das medidas de responsabilização das famílias pobres.

\subsection{3.}

\section{A violência nos documentos de monitoramento e avaliação: a definição do campo de intervenção da PSE de média complexidade}

Os documentos relacionados ao eixo de monitoramento e avaliação contemplam o processo de revisão contínua da Política de Assistência Social, estabelecendo os parâmetros para a sistematização dos resultados alcançados, como para a análise dos efeitos ou lacunas das ofertas previstas. Contempla os mecanismos de avaliação do SUAS, com a definição de categorias e indicadores específicos, a depender do eixo protetivo em questão. Portanto, a fase do monitoramento objetiva fomentar alterações no decurso da implementação, enquanto estratégia que propicia um exercício de revisão cotidiana dos serviços, como a análise do processo macro de formulação da Política. 
O estudo do processo de monitoramento e avaliação da Política de Assistência Social, com destaque para a abordagem da violência no processo de sistematização da PSE de média complexidade, contemplou os seguintes documentos: Parâmetros Nacionais para o Registro de Informações relativas aos serviços dos CRAS, CREAS e Centro POP/2011; Manual de Instruções para o Registro Mensal de Atendimentos do CREAS/2014 e 2018; e, Manual Prontuário SUAS/2014.

Para a análise do eixo de monitoramento e avaliação, a pesquisa revisou os instrumentais e respectivos manuais explicativos utilizados para a sistematização da produção cotidiana dos CREAS - formulários de Registro Mensal de Atendimentos (RMA) e o prontuário das famílias e indivíduos. O estudo priorizou identificar a abordagem da violência nos documentos, adequando as perguntas do roteiro ao perfil da publicação. Trata-se de uma observação necessária, tendo em vista o predomínio do perfil instrumental e descritivo dos documentos selecionados.

Instituída em 2011, a resolução relativa aos parâmetros nacionais ${ }^{59}$ para o registro das informações dos CRAS e CREAS estipulou as categorias e critérios para avaliação dos perfis das famílias e indivíduos atendidos e/ou acompanhados nos respectivos serviços das unidades socioassistenciais da PSB e PSE de média complexidade. Em relação ao segundo eixo protetivo, objeto de análise da pesquisa, cumpre destacar a introdução do termo violência intrafamiliar, enquanto categoria que aglutinaria demais expressões de violência manifestas nas relações familiares e interpessoais.

O instrumental determina, assim, um conjunto de informações a serem consolidadas mensalmente, a conferir: volume e o perfil dos casos - famílias ou indivíduos - em acompanhamento pelo PAEFI; a quantidade de situações identificadas de violência intrafamiliar ou de violações de direitos que originam o acompanhamento das famílias ou indivíduos pelo PAEFI; e, o volume de adolescentes em cumprimento de Medida Socioeducativa - MSE em acompanhamento do respectivo serviço no CREAS.

59 Em 2013, foi publicada a Resolução no 20, que incluiu o formulário referente ao CENTRO POP. A atualização, publicada em 2017, inclui o perfil da primeira infância - 0 a 6 anos - no perfil etário, em complemento aos ciclos geracionais. Ressalta-se que os demais campos permaneceram inalterados. 
Quanto às situações de violência intrafamiliar ou de violações de direitos, atendidas no âmbito do PAEFI, a publicação propõe quantificar: crianças ou adolescentes vítimas de violência intrafamiliar; crianças ou adolescentes vítimas de abuso sexual; crianças ou adolescentes vítimas de exploração sexual; crianças ou adolescentes vítimas de negligência ou abandono; crianças ou adolescentes em situação de trabalho infantil; pessoas idosas - 60 anos ou mais - vítimas de violência intrafamiliar; pessoas idosas - 60 anos ou mais - vítimas de negligência ou abandono; pessoas com deficiência, vítimas de violência intrafamiliar; pessoas com deficiência vítimas de negligencia ou abandono; mulheres adultas - 18 a 59 anos - vítimas de violência intrafamiliar; pessoas vítimas de tráfico de seres humanos; pessoas vítimas de discriminação por orientação sexual; pessoas em situação de rua.

A análise da publicação contrasta com a tendência de supressão da violência apontada nos tópicos anteriores, em que pese o destaque conferido às expressões de violência nas dinâmicas familiares e interpessoais. Se a abordagem do fenômeno nos documentos de formulação e operacionalização tende a mencioná-lo como consequência das situações de risco social e pessoal, os documentos que orientam a sistematização do PAEFI exploram as expressões e categorias que tipificam a violência como principais elementos de caracterização do público em acompanhamento na PSE de média complexidade.

Em complemento, o Manual de Instruções do $\mathrm{RMA}^{60}$ contempla as orientações para o preenchimento do formulário, sendo apresentado como um documento de suporte para as equipes do CREAS. A partir da análise de sua estrutura, é possível afirmar a relevância da publicação para a interpretação dos desígnios do PAEFI, para além do caráter instrumental explorado nas linhas introdutórias do documento. O Manual apresenta as definições e expressões de violência demarcadas como campo de intervenção da Política de Assistência Social, no eixo de atenção da PSE de média complexidade.

60 A análise avaliou a versão atualizada do Manual. Contudo, a publicação foi lançada em 2011, em complemento ao RMA. É importante destacar que a análise comparou as versões, com o intuito de apurar as definições de violência utilizadas. As categorias e descrições das expressões de violência não sofreram alterações. As atualizações incorporaram as questões que foram incluídas no RMA, como as questões afeitas ao CENTRO POP e a categorização da primeira infância. 
Com efeito, a publicação reporta a compreensão da Política acerca das expressões de violência contempladas no RMA do CREAS. O documento apresenta e caracteriza a violência intrafamiliar, violência doméstica, violência psicológica, violência física, violência sexual, abuso sexual, exploração sexual, negligência, abandono, tráfico de seres humanos, discriminação por orientação sexual, pessoas em situação de rua - tomados como elementos de síntese das dinâmicas violadoras que atravessam as famílias.

Importa destacar que o debate das referências teóricas não foi incorporado à pauta de análise, considerando, dentre outros aspectos, o limite da pesquisa por ora empreendida. O estudo priorizou a interpretação do viés aplicado ao fenômeno da violência, com o privilégio de expressões relacionadas às dinâmicas familiares e das relações interpessoais. A Política explicita, nos documentos de registro e avaliação, o recorte de violência que elege como pauta para a sua intervenção.

Trata-se do investimento em sistematizar dados que apontam as violências perpetradas e vividas pelas famílias, cujos registros são segmentados pelo recorte de classe, gênero e geração. A partir do detalhamento das expressões da violência intrafamiliar, é definido um viés de análise, tal como sugere o diálogo com as contribuições de Michel Misse (2016), no Capítulo II, a considerar o público preferencial dos serviços socioassistenciais, famílias e indivíduos vulneráveis, e as dimensões de violência escolhidas para caracterizá-los. Importa considerar que a Política opera com um recorte de violência e com a seleção de um público em particular, para o qual se volta as medidas de correção e de ajustamento de projetos de vida - tomadas como garantias das seguranças afiançadas pela Política.

Cabe indagar a direção que a Assistência Social assume ao explorar categorias de amplitude, tal como risco social, ao longo das normativas de concepção da Política e a tendência por reduzir o fenômeno da violência às manifestações relacionais, no contexto da sistematização dos dados e informações do campo socioassistencial. A correlação entre as situações de risco e os indicadores socioassistenciais que privilegiam a leitura da família como violadora de direitos é iminente, considerando se tratar da sentença que legitima a PSE de média complexidade - eixo protetivo voltado para famílias e indivíduos em situação de risco social e pessoal, por violação de direitos. 
Como pontuado, a pesquisa problematiza o apelo idílico do cuidado, como atributo naturalizado e, portanto, acreditado às famílias. A Política de Assistência Social reivindica, como os formulários de avaliação corroboram, a avaliação da capacidade de proteção manifesta pela família em situação de pobreza, mobilizando para esta estimativa categorias que admitem uma interpretação unilateral - qual seja, a instância designada ao cuidado é mesma que reproduz as violações, estabelece o contexto de risco social e pessoal, e para a qual são projetadas as medidas de proteção.

O manual do Prontuário SUAS, assim como as instruções do RMA, orienta o registro das informações e atualizações do acompanhamento familiar no âmbito do CRAS e CREAS. De acordo com o objeto da pesquisa, a análise de deteve aos tópicos do instrumento detido às situações de violência e violação de direitos, cujo preenchimento é destinado às equipes da PSE de média complexidade. O formato das orientações é similar ao identificado nas instruções do registro mensal, de modo que o documento recupera as mesmas categorias e definições para ilustrar as expressões de violência atribuídas à PSE de média complexidade.

Vale pontuar, em adição, que o prontuário incorporou o conceito de violência e violação de direitos, referenciais inéditos para a Política, considerando que os documentos de formulação e execução se detiveram, tão somente, a caracterizá-los como o recorte de atuação da Proteção Especial. Ainda que a pesquisa não tenha se voltado para problematizar a definição teórica ou normativa das categorias, cabe ponderar a referência incorporada para a interpretação do conceito de violência e o registro bibliográfico do termo.

A normativa adotou o registro de violência ${ }^{61}$ preconizado pela Organização Mundial de Saúde (OMS), o qual foi extraído do documento Linha de Cuidado para a Atenção Integral à Saúde de Crianças, Adolescentes e suas Famílias em Situação de Violências. Ressalta-se o fato de o manual explorar uma referência da Política de Saúde, considerando a ausência de encaminhamentos sobre a temática nos documentos de concepção da Assistência Social. Decerto, a Política de Saúde reúne produções de destaque na área, contudo, faz-se necessário

61 Para a OMS, a violência se configura com o uso intencional da força física ou do poder, real ou em ameaça, contra si próprio, contra outra pessoa, ou contra uma comunidade, que resulte ou tenha grande possibilidade de resultar em lesão, morte, dano psicológico, deficiência de desenvolvimento ou privação (BRASIL, 2010). 
questionar o vácuo nas produções socioassistenciais, tendo em vista que a Política de Assistência Social investe em atenções específicas para expressões do fenômeno desde, pelo menos, a década de 1990.

A análise do documento pondera se o destaque para o referencial de violência possui relação com a ampliação das variáveis de registro das situações de violação de direitos vivenciadas pelas famílias e/ou indivíduos em acompanhamento. Ao apresentar os tipos de violação de direitos e violência, o manual discrimina as seguintes ocorrências: trabalho infantil, exploração sexual, abuso sexual, violência psicológica, violência física, negligência, abandono, trajetória de rua, tráfico de pessoas, violência patrimonial contra a pessoa idosa ou pessoa com deficiência e a opção outra. A última alternativa possibilita o registro de violações de direitos que extrapolam a ocorrência para além dos limites das relações familiares.

Para ilustrar tipologias de violações que demandam as medidas de proteção da Assistência Social, o manual sugere: afastamento do convívio familiar devido à aplicação de medida socioeducativa; afastamento do convívio familiar devido à aplicação de medida de proteção; discriminação em decorrência da orientação sexual; discriminação em decorrência da raça/etnia; descumprimento de condicionalidades do PBF e do PETI em ocorrência de violações de direitos; exploração da imagem; famílias com membros em situação de desaparecimento; violência moral; bullying; e, violência institucional.

O documento identifica expressões de violência e violações de direitos relevantes, que expandem o referencial do fenômeno para a Política, ao assumir distintos atores e circunstâncias como partícipes da engrenagem que o envolve. Ainda que se reconheça a importância da ampliação, a discussão insiste na ausência de ocorrências que reconheçam o Estado como violador de direitos, bem como problematiza o viés seletivo dos marcadores de violência que balizam a produção de dados relacionados à PSE de média complexidade. Em outras palavras, a inclusão de outras nuances de violência fica restrita ao registro individual das famílias, ao passo que as informações publicizadas a respeito do PAEFI reforçam um retrato social que atribui ocorrências violadoras às famílias em situação de pobreza. 
O tópico relacionado ao registro das avaliações das dinâmicas de convivência intrafamiliar reúne os principais aspectos críticos suscitados ao longo da análise. O Prontuário destina um campo específico, ilustrado abaixo, para a inclusão de informações sobre a avaliação técnica das relações de convivência familiar - relações conjugais, relações entre pais/responsáveis e filhos, relação entre irmãos e demais membros da família - da família atendida/acompanhada, enfatizando as situações de conflito que possam produzir, nas palavras do manual, vulnerabilidades relacionais (BRASIL, 2014).

Figura 4 - Quadro de avaliação das relações de convivência familiar

\begin{tabular}{|c|c|c|}
\hline Percepção/Avaliação do técnico sobre as relaçōes conjugais na familia, se for o caso & Nome do Técnico & $\begin{array}{c}\text { Data } \\
\text { (Mes/Ano) }\end{array}$ \\
\hline () Conflituoso, com violência () Conflituoso, sem violência () Sem conflitos relevantes & & $\longrightarrow$ \\
\hline () Conflituoso, com violência () Conflituoso, sem violência () Sem conflitos relevantes & & $\ldots$ \\
\hline () Conflituoso, com violência () Conflituoso, sem violência () Sem conflitos relevantes & & -1 \\
\hline $\begin{array}{l}\text { Percepção/Avaliaçâo do técnico sobre as relações entre pais/responsáveis e os filhos } \\
\text { inclusive entre o padrasto ou madrasta com o(s) enteados(as), se for o caso }\end{array}$ & Nome do Técnico & $\begin{array}{c}\text { Data } \\
\text { (Més/Ano) }\end{array}$ \\
\hline () Conflituoso, com violência ( )Conflituoso, sem violência () Sem conflitos relevantes & & 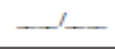 \\
\hline ( ) Conflituoso, com violência ( )Conflituoso, sem violência () Sem conflitos relevantes & & -1 \\
\hline () Conflituoso, com violência () Conflituoso, sem violência () Sem conflitos relevantes & & $\ldots$ \\
\hline Percepçâo/Avaliaçāo do técnico sobre as relaçōes entre os irmãos, se for o caso & Nome do Técnico & $\begin{array}{c}\text { Data } \\
\text { (Més/Ano) }\end{array}$ \\
\hline () Conflituoso, com violência () Conflituoso, sem violência () Sem conflitos relevantes & & $\ldots$ \\
\hline ( ) Conflituoso, com violência ( )Conflituoso, sem violência () Sem conflitos relevantes & & -1 \\
\hline () Conflituoso, com violência ( ) Conflituoso, sem violência () Sen & & $\ldots$ \\
\hline
\end{tabular}

"A descriçāo ou detalhamento dos conflitos intrafamiliares, quando pertinente, poderá ser realizada na página ao lado. Indique se há relaçōes conflituosas envolvendo outros individuos que residam no domicilio?

ـ ـ Sim, com presença de violência. Caso sim, utilize a página ao lado para anotar as informaçōes relevantes.

ـ Sim, sem presença de violência. Caso sim, utilize a página ao lado para anotar as informaçōes relevantes.

ـ Nảo há conflitos relevantes envolvendo outros individuos que residam no domicilio.

A avaliação das relações familiares é alçada como atributo da Política, competência das equipes responsáveis pelo acompanhamento especializado da PSE de média complexidade. Questionar o atravessamento da Assistência Social no padrão das relações tecidas pelas famílias é fundamental, por se tratar, em última instância, de um enquadramento moral reproduzido pelo Estado. Desta feita, as avaliações ditas técnicas partem da compreensão da violência enquanto elemento que se atribui às famílias em situação de pobreza. Neste contexto, a produção de dados que vincula expressões de violência às famílias vulneráveis reafirma, majoritariamente, o viés disciplinador que se alinha às medidas de proteção dispostas na Política de Assistência Social. 


\subsection{4.}

\section{A violência no eixo de formação continuada: a dualidade protetiva e punitiva como pauta de discussão da Política de Assistência Social.}

O debate do presente tópico envolve a análise do documento Proteção social no SUAS a indivíduos e famílias em situação de violência e outras violações de direitos: fortalecimento da rede socioassistencial, elaborado em parceria entre o MDS e a Fundação Oswaldo Cruz (FIOCRUZ). Publicado em 2018, o caderno pedagógico foi desenvolvido por ocasião do Programa de Formação de Trabalhadores do SUAS, capitaneado pela Escola Fiocruz de Governo e pela Secretaria Nacional de Assistência Social (SNAS).

A publicação integra a Política Nacional de Educação Permanente (PNEP) do SUAS, enquanto estratégia de qualificação profissional e consequente aprimoramento dos serviços socioassistenciais. Em linhas gerais, a estrutura da publicação parte da apresentação do SUAS e da discussão sobre os conceitos de vulnerabilidade social, risco pessoal e social, violação de direitos e violência e as interfaces com a PSB e PSE. Contempla, ainda, a abordagem do conceito violência e sua incidência na sociedade brasileira, bem como as demandas para a identificação e acompanhamento das situações de violência no âmbito da PSE.

O material reconhece a ausência do debate sobre a violência nas normativas da Política de Assistência Social, destacando na apresentação que "mesmo se deparando frequentemente com a problemática da violência, ainda não haviam tido a oportunidade de refletir de forma sistematizada e organizada sobre ela" (BRASIL, 2018). A despeito da discordância quanto ao argumento da falta de oportunidade, considerando o privilégio que a abordagem da violência assume nos documentos de monitoramento e avaliação da Política, é necessário reconhecer a relevância da produção para o debate dos encaminhamentos da PSE de média complexidade na atualidade.

O documento sustenta uma discussão teórica e metodológica densa, com o aporte de referências que identificam as expressões de violência que se estabelecem como campo de intervenção da Política de Assistência Social movimento que suscita críticas, mas, decerto, repara uma lacuna da estrutura normativa da Política. É possível reconhecer, portanto, um investimento por 
qualificar o eixo protetivo da PSE de média complexidade, a começar pelo debate de aspectos estruturais da violência no Brasil e dos determinantes macrossociais dos recortes de violência que incidem nas dinâmicas familiares. De antemão, fazse necessário pontuar que a análise não esgotará o diálogo com o documento, priorizando aspectos da definição dos recortes de violência passíveis de intervenção da Assistência Social.

O capítulo de abertura explora definições de violência, a partir da perspectiva histórica e cultural do fenômeno. O debate mobiliza a interpretação da violação de direitos articulada às diversas expressões de violência que atravessam a sociedade brasileira, estipulando que "todas as formas de violência constituem uma violação de direitos. A recíproca não é, em princípio, verdadeira, isto é, nem toda violação de direitos corresponde a uma violência” (BRASIL, 2018, p. 27). Trata-se de uma distinção relevante e inédita nas publicações socioassistenciais, desde a formalização do vínculo das situações de risco e violações de direito como justificativa para a intervenção da PSE de média complexidade.

Ao destacar a abordagem central de violência da publicação, o conceito da OMS é retomado, tal como a menção no manual do Prontuário SUAS. Contudo, o material se propõe em aprofundar o debate, ao problematizar distintas dimensões que o fenômeno abrange - “compreende a violência não apenas como ato em que se utiliza de força física e, por isso, inclui a noção de poder para abranger outras situações como, por exemplo, atos de omissão, negligência, ameaças, atos de coerção e de humilhação (...)" (BRASIL, 2018, p. 34).

A interpretação da definição da OMS orienta uma divisão em categorias, pautada em quem comete o ato de violência e a distinção do mesmo segundo sua natureza (BRASIL, 2018). De acordo com o esquema de análise da publicação, as categorias de quem perpetra a violência considera as tipificações: auto infligida; interpessoal e coletiva. No tocante à natureza dos atos violentos, estipula as seguintes violências: física, psicológica, negligência e abandono e sexual. Em complemento, discorre sobre as dimensões macrossociais e microssociais da violência, articuladas como condicionantes ${ }^{62}$ da conjuntura vivenciada.

$62 \mathrm{O}$ documento explica que a opção pelo termo condicionamento e não determinação se deve ao entendimento que “(...) quando se trata de sociedades, mesmo estruturas que pareçam mais sólidas são construídas, desconstruídas e assumem novas formas por meio da ação do coletivo de sujeitos que a compõem" (BRASIL, 2018, p. 40). 
Com base nessa linha de argumentação, a publicação sustenta, a partir do diálogo com Minayo e Souza (1999), o tripé que informa as perspectivas do trabalho em situações de violência: atuar no que é específico dentre as atribuições da política pública; intervir nas situações de riscos e nas causas geradoras, integrando as medidas de prevenção e proteção/reparação; e, atuação tanto nos aspectos micro indivíduo e grupo, como nos fatores macrossociais - contexto e estrutura.

Com efeito, o documento investe na ampliação do referencial de análise sobre a violência por parte do profissionais do SUAS, associando formulações teóricas ao estudo de casos reais - tática metodológica que propicia, para além da aproximação com o cotidiano das equipes dos serviços de acompanhamento, a assimilação de distintas expressões da violência e desigualdades estruturais que atravessam as trajetórias das famílias e indivíduos que se apresentam como público da Política.

Contudo, a linha de argumentação do documento tende a justificar o campo de intervenção da Política de Assistência Social dedicado às expressões de violência manifestas nas relações familiares, não obstante os aspectos macrossociais incorporados à compreensão do fenômeno ao longo da publicação. O trecho em destaque é contundente para ilustrar tal assertiva:

Neste ponto, chamamos a atenção especialmente dos e das trabalhadoras do SUAS, pois, no âmbito do Estado e das políticas públicas, esses aspectos são fundamentais e devem orientar todas as ações [dimensão macrossocial e estrutural da violência]. Porém, cada política pública tem competências legais especificamente relacionadas com cada dimensão da violência. No campo da Assistência Social a preocupação é com a proteção das famílias e indivíduos vítimas de vulnerabilidade e risco por direitos violados, dentre os quais a violência física e ou psicológica, porque esta condição fragiliza famílias e indivíduos e as condições de se cuidarem e se protegerem (BRASIL, 2018, p. 38)

A pesquisa identificou, enquanto estratégia de arguição do documento, a tendência de mobilizar dados de violência estruturais, como a elevada taxa de homicídios da população negra, indicadores recentes de feminicídio e denúncias de violência contra a mulher, desigualdade racial associada ao gênero, acompanhado de registros das dinâmicas familiares e interpessoais, mobilizando, para tanto, informações dos atendimentos do PAEFI, extraídos do RMA. 
Para além dos tipos de violência aqui mencionados, que de diferentes maneiras fazem parte do cotidiano das camadas sociais atendidas nos equipamentos do Sistema Único de Assistência Social (SUAS), há ainda variados outros tipos que requerem o cuidado e a atenção dos serviços de assistência social e das equipes de referência. A partir de análise de dados do RMA, por exemplo, estima-se que no ano de 2015 cerca de 150.000 crianças e adolescentes vítimas de violência ou de violação de direitos foram atendidas nos Centros de Referência Especializados de Assistência Social (CREAS), por meio do Serviço de Proteção e Atendimento Especializado a Famílias e Indivíduos (PAEFI). (BRASIL, 2018, p. 11)

A publicação, ao delimitar o campo de intervenção restrito às ocorrências relacionais, incorre numa lógica paradoxal, tendo em vista a defesa de elementos estruturais para a análise dos casos direcionados aos serviços. Se a esfera de competência da Política se detém às manifestações do âmbito privado, a publicação desconsidera que estas ocorrências reproduzem e incorporam aspectos da violência macro, o que impediria a demarcação de um recorte com limites tão específicos. Ao tomar como exemplo os indicadores de letalidade de jovens negros, divulgado pelo documento, faz-se necessário indagar quais os condicionantes para o exercício protetivo das famílias que experimentam a perda motivada pela violência estatal?

Ao destacar como a dimensão particular da Assistência Social as expressões da violência que incidem e são perpetradas pelas famílias, como ocorrências que demandam a atenção especializada da Política, a publicação assente com o recorte da atuação da PSE de média complexidade, bem como legitima a produção de dados que reproduz, majoritariamente, o retrato das violações de direito perpetradas pelas famílias pobres. Reafirma-se que o panorama dos dados e indicadores socioassistenciais do PAEFI não permitem o exercício de ampliação analítica indicada pelo documento, impedimento que remonta à própria lógica paradoxal da Política defendida ao longo da dissertação - a garantia de direitos concomitante à reprodução de medidas de controle e disciplinamento punitivos. 


\section{5.}

\section{Considerações Finais}

A presente dissertação objetivou analisar as concepções que qualificam o campo de intervenção e, em consequência, definem as expectativas de proteção atreladas à Política de Assistência Social no atendimento às situações de violência. A produção se voltou para a investigação do ciclo da PNAS/2004, a partir da análise dos documentos e normativas que delimitaram, no decurso dos últimos catorze anos, o campo de intervenção da PSE de média complexidade. O estudo pautou a avaliação da Política de Assistência Social sob a ótica da correlação entre a reparação de direitos e o controle punitivo, a considerar o privilégio das expressões de violência intrafamiliar e de conflitos interpessoais como ocorrências que balizam o escopo de atuação da PSE de média complexidade.

O estudo destacou aspectos basilares da Assistência Social como uma política que compõe o sistema de proteção social, envolta, portanto, no cenário de contradições que envolvem as políticas sociais no capitalismo. As ambiguidades exploradas, ao longo dos capítulos, remontam aos limites e possibilidades de uma política social necessária para o processo de reprodução da força de trabalho e ao atendimento de reinvindicações e demandas da classe trabalhadora atravessamentos que o acervo documental da PNAS/2004 insiste em negligenciar.

Ao retomar as protoformas das iniciativas de proteção mobilizadas pelo Estado nos países do capitalismo central, a análise buscou destacar a violência como parte do processo de desenvolvimento das ações assistenciais. A associação entre os ritos de punição e as medidas protetivas se destaca no decurso da imposição do primado do trabalho, enquanto recurso de disciplinamento necessário para legitimar os termos da venda e compra da força de trabalho nos moldes do modo de produção capitalista.

O estudo investiu na articulação de processos que se reatualizam, considerando as injunções históricas das respostas assistenciais em análise. A recomposição do histórico das políticas sociais no Brasil e, em particular, da assistência social, decorre dessa prerrogativa, considerando o destaque à formação social do capitalismo no país. No tópico em questão, a argumentação assinalou tendências que atravessam as diferentes versões institucionais da política, de modo 
que a convergência entre medidas protetivas e recursos punitivos é reconhecida como elemento que dá forma à trama assistencial brasileira.

A pesquisa assumiu o desafio de reconhecer, no ordenamento atual, determinado pelos princípios da racionalidade neoliberal, as particularidades contemporâneas da Política de Assistência Social que imprimem sentido e direção ao binômio proteção e punição na PNAS/2004. O eixo protetivo vinculado à PSE de média complexidade veicula princípios da responsabilização das famílias, característica que tende a reforçar uma perspectiva de individualização indiscriminada que, em tempos de domínio da razão neoliberal, avança para todos os processos da vida social.

A pergunta que orientou o percurso da investigação exigiu o confronto de proposições teóricas acerca da violência, tendo em vista o predomínio descritivo do fenômeno na estrutura normativa da PNAS/2004. A discussão reforçou que a ausência de um recorte para a intervenção e a própria abordagem descritiva da violência nos documentos orientadores da Política, e da PSE em especial, reportam uma compreensão particular do fenômeno, a considerar o público alvo de suas ações. O estudo, assim, explorou as omissões e aspectos privilegiados pela Política, de modo a problematizar a opção por categorias generalistas nos documentos de formulação, tal como risco social e pessoal, e conceitos específicos naqueles voltados à produção e sistematização da prática cotidiana do PAEFI.

Nesse contexto, a pesquisa ressaltou que o modelo de proteção e garantia dos direitos socioassistenciais admite, ao mesmo tempo, estratégias de disciplinamento, embora assegure princípios e garantias indispensáveis à reprodução social e defesa de direitos humanos - considerando a mencionada regressão dos direitos advindos da relação salarial formal e o avanço da mercantilização das políticas sociais, além da mobilização em prol de agendas progressistas, como o enfrentamento ao trabalho infantil, à violência sexual e ao tráfico de pessoas. A despeito da condição paradoxal que atravessa os quadros da Assistência Social, traços conservadores da Política são permanentemente atualizados, sendo a correlação da violência e pobreza decisiva para elucidar essa sentença.

Ao se debruçar nas produções detidas ao eixo da PSE de média complexidade, a investigação explorou a transição temporal da abordagem ao 
fenômeno da violência nas publicações, movimento que viabilizou a produção de dados qualitativos e a sistematização dos resultados apontados no decorrer da dissertação. A análise, centrada dos documentos do ciclo de formulação, operacionalização, avaliação e monitoramento e formação continuada, apontou elementos de continuidade - como a capacidade protetiva atribuída às famílias, enquanto traço cativo do discurso socioassistencial - e a correção de rotas, tal como o privilégio pela articulação com o SGD em substituição estratégica da menção ao Sistema de Justiça - ainda que insuficiente para reverter a tendência de controle das intervenções socioassistenciais.

O esforço de síntese da pesquisa reconhece, ainda, a transição das justificativas que delimitaram a PSE de média complexidade nos documentos de formulação da PNAS/2004. A definição corrente supõe o acompanhamento especializado de famílias e indivíduos em situação de risco social e pessoal, por violação de direitos, enquanto atributos do PAEFI - sentença que substituiu a fragilidade de vínculos familiares e comunitários como premissa da intervenção do CREAS, ainda que a preservação das conexões relacionais prossiga no rol das garantias socioassistenciais.

Demarcar as transições da PSE de média complexidade contribuiu para elucidar as questões levantadas sobre as concepções de violência que informam o escopo de intervenção da Política. Ao averiguar sua história recente, foi possível reconhecer os recuos e substituições dos termos que passaram a embasar e mobilizar respostas ao fenômeno da violência nas normativas. O estudo permitiu correlacionar, por conseguinte, a adoção da categoria violação de direitos à pauta de debates dos Direitos Humanos, prerrogativa que admite a ampliação do repertório das expressões de violência da PSE de média complexidade, centrado, até então, nas relações familiares e interpessoais.

Em complemento, ao situar a substituição dos vínculos pela categoria violação de direitos, a pesquisa avançou no debate que circunda a perspectiva de reparação do campo socioassistencial. Nesse contexto, foi possível destacar o movimento da Política em situar as alternativas de reversão pelos recursos de adaptação e correção das próprias famílias, perspectiva que reivindica, novamente, o investimento na capacidade naturalizada de proteção. Para tanto, a PSE de média complexidade oferta uma proposta de acompanhamento assentada na revisão de 
condutas, intervenções que restaurem padrões de cuidado e medidas de responsabilização.

Aqui reside um aspecto de destaque do estudo, ao considerar os pilares da intervenção especializada da Política - que considera, para além da atenção específica do PAEFI, a atuação intersetorial da Assistência com as demais políticas e instituições que compõe o SGD. A pesquisa ressaltou distintos limites que as políticas atravessam na lógica de mercantilização contemporânea, com severas repercussões para o sentido de proteção social afiançada pelo Estado. Outro ponto decisivo da investigação reporta a relação travada com o Sistema de Justiça, em que pese o debate sobre o viés de controle que as sanções legais podem incutir ao público em acompanhamento no PAEFI, como o cerceamento das práticas e imposição de limites à autonomia técnica dos profissionais vinculados ao CREAS.

O estudo contemplou a relação da PSE de média complexidade com o Sistema de Justiça em distintos tópicos da análise, sendo possível apreciar os trâmites dispostos na normativa do Programa Sentinela, a previsão de atendimento compartilhado no primeiro Guia de Implementação do CREAS, ao processo de reconhecimento público dos limites do vínculo da Política com instâncias do Judiciário, iniciado em 2011, e a elaboração de uma nota técnica que objetiva disciplinar a relação entre os Sistemas - SUAS e Sistema de Justiça.

Com efeito, faz-se necessário ressalvar dois pontos de destaque: o primeiro posiciona as problematizações levantadas pelos documentos da Política, as quais privilegiam as repercussões institucionais, quando as medidas de cunho coercitivo dirigida às famílias carecem de visibilidade no exercício de crítica da Assistência Social; além das ressalvas quanto à estrutura da própria Política, considerando que os contornos programáticos e normativos da PNAS/2004 e documentos posteriores, colaboraram para os descaminhos apurados, em que pese o panorama de riscos e processos violadores que determinam o seu público alvo e a adoção de medidas de reparação de direitos atreladas à esfera subjetiva e deliberações intersetoriais, com singular reforço das medidas de responsabilização das famílias pobres.

Em consequência, a Política de Assistência, mais precisamente nos termos da PSE de média complexidade, reproduz uma estrutura de acompanhamento especializado que consente com a identificação prévia das vítimas, dos violadores, dos atores que responsabilizam e enquadram e, por assim dizer, de quem executa 
os expedientes - este último, destinado, não sem resistências, aos profissionais do SUAS. Ou seja, o aparato socioassistencial admite práticas de controle e disciplinamento enquanto tendência histórica da Assistência Social no Brasil.

Os argumentos críticos, que suscitaram o estudo em questão, partem da interpretação da PSE de média complexidade enquanto componente de uma agenda pública em disputa, passível, portanto, de apropriação por frentes progressistas e/ou como partícipe da engrenagem que legitima a repressão e o controle punitivo da pobreza. Diante desse contexto, o estudo ambicionou ter contribuído para a interpretação dos desígnios atuais da Política de Assistência Social, com a expectativa de retroalimentar resistências frente à barbárie que atravessa a experiência do viver nos dias que seguem. 


\section{6.}

\section{Referências}

ADORNO, S. A violência na sociedade brasileira: um painel inconcluso em uma democracia não consolidada. Revista Sociedade e Estado, vol. X, n. ㅇ 2, jul/dez: 299- 342, 1995.

ALCHORNE, S. 20 anos de LOAS - análise das normativas nacionais. O Social em Questão, ano XVII, n. 30, 2013.

AMORIM, P. K. Controle social sobre a classe trabalhadora: as interfaces entre as políticas de assistência social e criminal. Tese (Doutorado em Serviço Social) - UFRJ, 2015.

BEHRING, E. Brasil em contrarreforma: desestruturação do Estado e perda de direitos. São Paulo: Cortez, 2002.

, E. R; BOSCHETTI, I. Política social: fundamentos e história. 1 ed. São Paulo: Cortez, 2006.

,E. R. A condição da política social e a agenda da esquerda no Brasil. Revista Ser Social, v. 18, n. 38, 2016. Paulo: Cortez, 2016.

, I. Expropriação de direitos e reprodução da força de trabalho. In: BOSCHETTI, I. (org.). Expropriação e Direitos no Capitalismo. São Paulo: Cortez, 2018.

BRAVO, M. I. S. Serviço Social e reforma sanitária: lutas sociais e práticas profissionais. São Paulo/Rio de Janeiro: Cortez/Ed. UFRJ, 1996.

CELLARD, A. Análise documental. In: POUPART J., DESLAURIERS J.P., GROULX L.H., LAPERRIĖRE A., MAYER R., PIRES A. (org). A pesquisa qualitativa. Enfoques epistemológicos e metodológicos. Petrópolis: Editora Vozes, 2008.

CHAUÍ, M. O que é ideologia. São Paulo: Brasiliense, 2008.

COIMBRA, C.; SCHEINVAR, E. A convergência social/penal na produção e gestão da insegurança social. In: BATISTA, V. M. (org.). Loic Wacquant e a questão penal no capitalismo neoliberal. Rio de Janeiro: Revan, 2012.

COUTO, B. R; YAZBEK, M. C; SILVA, M. O. S; RAICHELIS, R. (org). O sistema único de assistência social no Brasil: uma realidade em movimento. 5 ed. São Paulo: Cortez, 2017.

DARDOT, P; LAVAL, C. A nova razão do mundo: ensaio sobre a sociedade neoliberal. São Paulo: Boitempo, 2016. 
DRAIBE, S. M. As políticas sociais brasileiras: diagnósticos e perspectivas. Para a década de 90: prioridades e perspectivas das políticas públicas. Brasília: IPEA/IPLAN, v. 4, 1990.

EMANOEL, M. R. S. M. Política Nacional de Assistência Social e conservadorismo: da concepção ao risco do desmonte. Revista de Políticas Públicas, v. 22, n. 2, 2018.

FALEIROS, V.P. Natureza e desenvolvimento das políticas sociais no Brasil. Política Social - Módulo 3. Programa de Capacitação Continuada para Assistentes Sociais. Brasília: CFESS/ABEPSS/CEAD-UnB, 2000.

FERNANDES, F. O que é revolução. In: PRADO Jr., C.; FERNANDES, F. (org). Clássicos sobre a revolução brasileira. São Paulo: Expressão Popular, 2000.

FLICK, U. Introdução à pesquisa qualitativa. Porto Alegre: Editora Artmed, 2009.

FONTES, V. O Brasil e o capital-imperialismo: teoria e história. Rio de Janeiro: EPSJV/Editora UFRJ, 2011.

, V. Capitalismo, crises e conjuntura. Revista Serviço Social e Sociedade, n.130, 2017.

FOUCAULT, M. Vigiar e punir: nascimento da prisão. Petrópolis: Vozes, 2014.

IAMAMOTO, M.; C., R. Relações Sociais e Serviço Social no Brasil esboço de uma interpretação histórico-metodológica. São Paulo: Cortez, 2003.

IANNI, O. A ideia de Brasil moderno. São Paulo: Brasiliense, 2004.

IPEA, Instituto de Pesquisa Econômica Aplicada. As relações entre o Sistema Único de Assistência Social e o Sistema de Justiça. Disponível em: http://pensando.mj.gov.br/publicacoes/?pub_id=1008668. Acesso em: 15/03/2019.

IPEA, Instituto de Pesquisa Econômica Aplicada; FBSP, Fórum Brasileiro de Segurança Pública. Atlas da Violência. Disponível em: http://www.ipea.gov.br/atlasviolencia/download/19/atlas-da-violencia-2019. Acesso em: 17/03/2020.

LÜDKE, M.; ANDRÉ, M.E.D.A. Pesquisa em educação: abordagens qualitativas. São Paulo: EPU, 1986.

MACHADO DA SILVA, L. A. Violência urbana: Representação de uma ordem social. In: NASCIMENTO, E. P.; BARREIRA, I. (org.). Brasil urbano: Cenário da ordem e da desordem. Rio de Janeiro: Notrya,1993.

MANDEL, E. O capitalismo tardio. São Paulo: Nova Cultural, 1982.

MARX, K. O capital: crítica da economia política. São Paulo: Boitempo, 2017. 
MIOTO, R. C. T.; DAL PRÁ, K. R. Serviços sociais e responsabilização da família: contradições da política social brasileira. In: MIOTO, R. C. T.; CAMPOS, M. S. C.; CARLOTO, C. M. (org.). Familismo, direitos e cidadania: contradições da política social. São Paulo: Cortez, 2015.

R. C. T. Famílias contemporâneas? Intervenções Contemporâneas? In: DE MARTINO, M. S.; GIORGI, V. (org). Miradas ibero-americanas sobre practicas familiares. Montevideo: EPAL, 2016.

R. C. T. Política Social e processos de judicialização: serviços sociais e famílias em foco. Revista Ser Social, v. 20, n. 42, 2018.

MISSE, M. Malandros, marginais e vagabundos e a acumulação social da violência no Rio de Janeiro. Tese (Doutorado em Sociologia) IUPERJ,1999.

. Sujeição criminal. In: LIMA, R. S.; RATTON, J. L.; AZEVEDO, R. G. (org). Crime, polícia e justiça no Brasil. São Paulo: Editora Contexto, 2014.

. Violência e teoria social. Dilemas: Revista de Estudos de Conflito e Controle Social, v. 9, n. 1, 2016

MONTANO, C. Terceiro Setor e Questão Social: crítica ao padrão emergente de intervenção social. São Paulo: Cortez, 2007.

MOTA, A. E. Questão Social e Serviço Social: um debate necessário. In: MOTA, A. E. (org.). O Mito da Assistência Social: ensaios sobre Estado, política e sociedade. São Paulo: Cortez, 2008.

MINAYO, M. C. S.; SOUZA, E. R. É possível prevenir a violência? Uma reflexão a partir do campo da saúde pública. Ciência \& Saúde Coletiva, v. 4, n. 1, 1999.

NASCIMENTO, M. L.; RODRIGUES, R. C. A convergência social/penal na produção e gestão da insegurança social. In: BATISTA, V. M. (org.). Loic Wacquant e a questão penal no capitalismo neoliberal. Rio de Janeiro: Revan, 2012.

NETTO, J. P. Cinco notas a propósito da "Questão Social". Revista Temporalis, ano 2, n. 3, 2001.

, J.P. O que é marxismo. São Paulo: Brasiliense, 2006.

POLANYI, K. A grande transformação: as origens da nossa época. Rio de Janeiro: Campus, 2000.

PORTO, M. S. G. A violência urbana e suas representações sociais: $O$ caso do Distrito Federal. São Paulo em Perspectiva, v. 13, n. 4, 1999.

PRADO Jr., C. Formação do Brasil contemporâneo. São Paulo: Brasiliense, 1991.

PRADO Jr, C. A revolução brasileira. In: PRADO Jr., C.; FERNANDES, F. (org). Clássicos sobre a revolução brasileira. São Paulo: Expressão Popular, 2000. 
RODRIGUES, N. C; VERAS, F. Q.; TEIXEIRA, R. Reminiscências da violência estatal: a reparação psíquica através de uma clínica política. Revista Psicologia: Ciência e Profissão, v. 37 (número especial), 2017.

SÁ-SILVA, J. R.; ALMEIDA, C. D.; GUINDANI, J. F. Pesquisa documental: pistas teóricas e metodológicas. Revista Brasileira de História \& Ciências Sociais, v. 1, n. 1, 2009.

SCHINKEL, W. Aspects of violence: A critical theory. Kent: Palgrave Macmillan, 2010.

SEN, A. Desenvolvimento como liberdade. São Paulo: Companhia das Letras, 2017.

SHIROMA, E. O.; CAMPOS, R. F; GARCIA, R. M. C. Decifrar textos para compreender a política: subsídios teórico-metodológicos para análise de documentos. Revista Perspectiva, v. 23, n. 02, 2005.

SPOSATI, A. Especificidade e intersetorialidade da política de assistência social. Revista Serviço Social e Sociedade, ano XXIV, n. 77, 2004.

SOUZA, C. Política públicas: uma revisão da literatura. Revista Sociologias, n. 16, 2006.

VIANNA, M.L. T. W. V. A americanização (perversa) da seguridade social no Brasil: estratégias de bem-estar e políticas públicas. Rio de Janeiro: Revan, 1998.

VIEIRA, O. V. Carandiru, uma autópsia da omissão. In: Carandiru não é coisa do passado: um balanço sobre os processos, as instituições e as narrativas após 23 anos após o massacre. São Paulo: FGV, 2015. Disponível em: https://direitosp.fgv.br/sites/direitosp.fgv.br/files/carandirunao-e-coisa-do-passado_1.pdf

WACQUANT, L. Punir os pobres: a nova gestão da miséria nos Estados Unidos. Rio de Janeiro: Editora Revan, 2013.

ZAFFARONI, E. R. Em busca das penas perdidas. Rio de Janeiro: Revan, 2001.

, E. R. O inimigo no direito penal. Rio de Janeiro: Revan, 2007.

ŽIŽEK, S. Violência: seis reflexões laterais. São Paulo: Boitempo, 2018.

\section{Legislações, Documentos, Projetos e Políticas}

BRASIL. Constituição da República Federativa do Brasil. Brasília, 1988.

BRASIL. Lei $n^{\circ}$ 8.742, de 7 de setembro de 1993. Dispõe sobre a organização da Assistência Social e dá outras providências.

BRASIL. Portaria № 878, de 03 de dezembro de 2001. Estabelece diretrizes e normas do Programa Sentinela e dá outras providências. 
BRASIL. Ministério da Saúde. Secretaria de Políticas de Saúde. Violência Intrafamiliar: orientações para a prática em serviço. Brasília, 2002.

BRASIL. Ministério do Desenvolvimento Social e Combate à Fome (MDS). Política Nacional de Assistência Social - PNAS. Brasília: MDS, 2004.

BRASIL. Ministério do Desenvolvimento Social e Combate à Fome (MDS). Conselho Nacional de Assistência Social. Resolução CNAS n. 130, de 15 de julho de 2005. Aprova a Norma Operacional Básica do Sistema Único de Assistência Social - NOB SUAS. Brasília: MDS, 2005.

BRASIL. Ministério do Desenvolvimento Social e Combate à Fome (MDS). Guia de orientação técnica do Centro de Referência Especializado de Assistência Social - CREAS (1 ${ }^{a}$ versão). Brasília: MDS, 2006.

BRASIL. Ministério do Desenvolvimento Social e Combate à Fome (MDS). Centro de Referência Especializado de Assistência Social - Revista CREAS, ano 2, n. 1, 2008.

BRASIL. Ministério do Desenvolvimento Social e Combate à Fome (MDS). Conselho Nacional de Assistência Social. Resolução CNAS n. 109, de 11 de novembro de 2009. Aprova a Tipificação Nacional de Serviços Socioassistenciais. Brasília, MDS: 2009.

BRASIL. Ministério da Saúde (MS). Linha de Cuidados para a Atenção Integral à Saúde de Crianças, Adolescentes e suas Famílias em Situação de Violências: orientações para gestores e profissionais de saúde. Brasília: MS, 2010a.

BRASIL. Ministério do Desenvolvimento Social e Combate à Fome (MDS). Orientações Técnicas sobre o Serviço de Convivência e Fortalecimento de Vínculos para Crianças e Adolescentes de 6 a 15 anos. Brasília: MDS, 2010b.

BRASIL. Ministério da Justiça. Comissão da Anistia. Anistia Política e Justiça de Transição. Brasília: MJ, 2010c.

BRASIL. Ministério do Desenvolvimento Social e Combate à Fome (MDS). O CRAS que temos, O CRAS que queremos. Orientações Técnicas: metas de desenvolvimento dos CRAS. Brasília: MDS, 2010-2011.

BRASIL. Ministério do Desenvolvimento Social e Combate à Fome (MDS). Orientações Técnicas: Centro de Referência Especializado de Assistência Social - CREAS. Brasília: MDS, 2011a.

BRASIL. Ministério do Desenvolvimento Social e Combate à Fome (MDS). Secretaria Nacional de Assistência Social. Comissão Intergestores Tripartite. Resolução CIT n. 4, de 24 de maio de 2011. Brasília: MDS, 2011b.

BRASIL. Lei $n^{\circ} 12.435$, de 6 de julho de 2011. Altera a Lei no 8.742, de 7 de dezembro de 1993, que dispõe sobre a organização da Assistência Social.

BRASIL. Ministério do Desenvolvimento Social e Combate à Fome (MDS). Orientações Técnicas sobre o PAIF: o Serviço de Proteção e 
Atendimento Integral à Família - PAIF, segundo a Tipificação Nacional de Serviços Socioassistenciais. Vol. II. Brasília: MDS, 2012a.

BRASIL. Ministério do Desenvolvimento Social e Combate à Fome (MDS). Caderno de Orientações Técnicas sobre o PAIF: trabalho social com famílias do Serviço de Proteção e Atendimento Integral à Família. Brasília: MDS, 2012b.

BRASIL. Ministério do Desenvolvimento Social e Combate à Fome (MDS). Conselho Nacional de Assistência Social. Resolução CNAS n. 33, de 12 de dezembro de 2012. Aprova a Norma Operacional Básica do Sistema Único de Assistência Social - NOB SUAS. Brasília: MDS, 2012c.

BRASIL. Ministério do Desenvolvimento Social e Combate à Fome (MDS). Caderno de Orientações Técnicas para o Programa Nacional de Promoção do Acesso ao Mundo do Trabalho - ACESSUAS TRABALHO. Brasília: MDS, 2012d.

BRASIL. Ministério do Desenvolvimento Social e Combate à Fome (MDS). Manual de instruções para utilização do Prontuário SUAS. Brasília: MDS, 2014.

BRASIL. Ministério do Desenvolvimento Social e Combate à Fome (MDS).

Orientações Técnicas da Vigilância Socioassistencial. Brasília: MDS, 2015.

BRASIL. Ministério do Desenvolvimento Social e Combate à Fome (MDS). Nota técnica sobre a relação entre o Sistema Único de Assistência Social - SUAS e os órgãos do Sistema de Justiça. Brasília: MDS, 2016.

BRASIL. Ministério do Desenvolvimento Social (MDS). Secretaria Nacional de Assistência Social. A Participação do SUAS no Programa Criança Feliz. Brasília: MDS, 2017.

BRASIL. Ministério do Desenvolvimento Social (MDS). Proteção social no SUAS a indivíduos e famílias em situação de violência e outras violações de direitos: fortalecimento da rede socioassistencial. Brasília: FIOCRUZ; MDS, 2018.

BRASIL. Ministério do Desenvolvimento Social (MDS). Manual de instruções para utilização do Prontuário SUAS. Brasília: MDS, 2018b. 
Anexo

\section{Anexo I}

\begin{tabular}{|c|c|}
\hline & Fase Inicial da Análise Documental \\
\hline & cumentos submetidos à análise para definição do universo da pesquisa \\
\hline 1 & Política Nacional de Assistência Social - PNAS/2004. \\
\hline 2 & Norma Operacional Básica - NOB/SUAS / 2005 \\
\hline 3 & Guia de Orientação do CREAS / 2006 \\
\hline 4 & $\begin{array}{l}\text { Norma Operacional Básica de Recursos Humanos do Sistema Único de } \\
\text { Assistência Social - NOB-RH/SUAS / } 2006\end{array}$ \\
\hline 5 & I Plano Decenal da Assistência Social 2007 (2005 a 2015) \\
\hline 6 & $\begin{array}{l}\text { Serviço de acolhimento para crianças e adolescentes / } 2009 \\
\text { Resolução Criança e Adolescente em Situação de Rua / } 2016 \\
\text { Resolução Diretrizes Atendimento Criança e Adolescente na rua / } 2017\end{array}$ \\
\hline 7 & $\begin{array}{l}\text { Protocolo de Gestão Integrada de Serviços, Benefícios e Transferências de } \\
\text { Renda no âmbito do Sistema Único de Assistência Social - SUAS / } 2009\end{array}$ \\
\hline 8 & $\begin{array}{l}\text { Tipificação Nacional dos Serviços Socioassistenciais / } 2009 \text { (com as } \\
\text { atualizações até 2014) }\end{array}$ \\
\hline 9 & Gestão das Condicionalidades CRAS e CREAS 2010 \\
\hline 10 & NOB RH/SUAS - Atualização / 2011 \\
\hline 11 & Atualização LOAS / 2011 \\
\hline 12 & $\begin{array}{l}\text { Orientações Técnicas: Centro de Referência Especializado para População } \\
\text { em Situação de Rua - CENTRO POP / } 2011\end{array}$ \\
\hline 13 & $\begin{array}{l}\text { Orientações Técnicas: Centro de Referência Especializado de Assistência } \\
\text { Social - CREAS / } 2011\end{array}$ \\
\hline 14 & Registro CREAS / 2011 - Atualização em 2013 e 2017 \\
\hline 15 & NOB SUAS / 2012 (Revoga a NOB 2005) \\
\hline 16 & Portaria Gestão das Condicionalidades / 2012 \\
\hline 17 & Reordenamento SCFV / 2013 \\
\hline
\end{tabular}




\begin{tabular}{|c|c|}
\hline 18 & Ações Estratégicas do PETI / 2013 \\
\hline 19 & Orientações Técnicas da Vigilância Socioassistencial / 2013 \\
\hline 20 & Manual Prontuário SUAS / 2014 \\
\hline 21 & Caracterização dos Usuários do SUAS / 2015 \\
\hline 22 & $1^{a}$ Infância no SUAS / 2016 \\
\hline 23 & Nota Técnica SUAS e Sistema de Justiça / 2016 \\
\hline 24 & II Plano Decenal da Assistência Social / 2016 \\
\hline 25 & Caderno de Medidas Socioeducativas / 2016 \\
\hline 26 & $\begin{array}{l}\text { Orientações Técnicas: atendimento no Suas às famílias e aos indivíduos em } \\
\text { situação de vulnerabilidade e risco pessoal e social por violação de direitos } \\
\text { associada ao consumo de álcool e outras drogas / } 2016\end{array}$ \\
\hline 27 & Lei n $^{\circ}$ 13.431 Criança e Adolescente Testemunha / 2017 \\
\hline 28 & Parâmetros Atendimento LGBT no SUAS / 2018 \\
\hline 29 & Pessoas Egressas Sistema Penitenciário no SUAS / 2018 \\
\hline 30 & $\begin{array}{l}\text { Curso Proteção Social no SUAS: Proteção social no SUAS a indivíduos e } \\
\text { famílias em situação de violência e outras violações de direitos: } \\
\text { fortalecimento da rede socioassistencial / } 2018\end{array}$ \\
\hline 31 & $\begin{array}{l}\text { Curso: A criança e sua família no contexto dos serviços socioassistenciais / } \\
2018\end{array}$ \\
\hline 32 & Manual RMA CREAS / 2018 \\
\hline
\end{tabular}

